$$
\begin{aligned}
& \text { UC,DAUIS RECQIVA DY OSTI } \text { DOE/ER/C0233-T4 } \\
& \text { FEB } 051992 \text { DE-FG03-84ER60233 } \\
& \text { PROGRESS REPORT } 1987
\end{aligned}
$$

PROGRAM GOAL: TO ANSWER' THE FUNDAMENTAL SCIENTIFIC QUESTIONS FOR THE DEVELOPMENT OF AN EFEECTIVE APPROACH FOR DELIVERING RADIATION THERAPY TO CANCER ON ANTIBODY-BASED RADIOPHARMACEUTICALS.

IN THE CURRENT GRANT PERIOD, 1985-1988, THE FOLLOWING LIST CONSISTS OF HIGHLIGHTS OF DEVELOPMENTS FROM OUR PROGRAM:

-DOCUMENTED THERAPEUTIC RESPONSE OF LYMPHOMA IN PATIENTS RECEIVING RADIOIMMUNOTHERAPY

- DEVELOPMENT AND APPLICATION OF QUANTITATIVE RADIONUCLIDE IMAGING TECHNIQUES FOR THERAPY PLANNING AND DOSIMETRY CALCULATIONS

-MULTICOMPARTMENTAL MODELING AND ANALYSIS OF THE IN VIVO MOAB KINETICS IN PATIENTS

- A MOAB MACROCYCLE CHELATE FOR CU-67: DEVELOPMENT, PRODUCTION, IN VITRO AND IN VIVO TESTING

-NMR ANALYSIS OF IMMUNORADIOTHERAPEUTIC EFFECTS ON THE METABOLISM OF LYMPHOMA

-ANALYSIS OF THE VARIABLE MOLECULAR CHARACTERISTICS OF THE MOAB RADIOPHARMACEUTICAL, AND THEIR SIGNIFICANCE

- IN VIVO STUDIES IN MICE AND PATIENTS OF THE METABOLISM OF RADIOIODINATED MOAB AS WELL AS IN-111 CITC MOAB

-BIODISTRIBUTION OF CU-67 TETA MOAB IN NUDE MICE WITH HUMAN LYMPHOMA

DURING THIS THREE-YEAR PERIOD, 32 PAPERS HAVE BEEN PUBLISHED OR ARE IN PRESS AT THIS TIME. TWENTY-FOUR ABSTRACTS HAVE BEEN PUBLISHED AND GREATER THAN 20 NATIONAL, AND EIGH? IVTERNATIONAL, INVITED LECTURES HAVE BEEN GIVEN.

\title{
DISCLAIMER
}

This report was prepared as an account of work sponsored by an agency of the United States Government. Nether Government nor any agency thereof, nor any of their employees, makes an les liability or responsibility for the accuracy, completeness, or isefulness of any information, apparatus, producl, or process disclosed, or represents that its use would not infringe privately owned rights. Reference herein io aiiy specific commercia! nrnduct, process, or service by trade name, trademark, manufacturer, or otherwise does not necessarily constitute or imply its endorsement, recommendation, or favoring by the United States Government or any agency tiereof. The views and opinions of authors expressed herein do not necessarily state or reflect those of the United States Government or any agency thereof.
DISTRIBUTTOS OF THIS DOCUMENT IS UNLIMITER 


\title{
BACKGROUND
}

\author{
UCD RADIOIMMUNOTHERAPY DOE PROGRAM
}

The effort of our group to use monoclonal antibodies and antibody-conjugates to treat cancer was initiated in 1979 while the principal investigator Sally DeNardo, M.D. and coinvestigator Gerald DeNardo, M.D., were on sabbatical leaves in the immunology laboratories of E. Benjamini, Ph.D., and Kent Erickson, Ph.D., and the biochemistry laboratories of R. Troy, Ph.D., respectively. Professor Benjamini is renowned for his work in immunology. Dr. Erickson was beginning his studies in cell mediated cytotoxicity (21-24). Professor Troy has interests in cell surface antigens of cancer cells and bacteria. Drs. Sally DeNardo and Kent Erickson, produced a monoclonal antibody against syngeneic mouse melanoma cells and this antibody conjugated with I-131 was used to successfully cure mice bearing this melanoma (1). This and subsequent experiences led the group to appreciate not only the potential of monoclonal antibodies and their conjugates for directed treatment of cancer and the complexities associated with these systems, but also led us to the conclusion that success or failure of the approach would depend on factors yet to be explored and underctood $(2,3,4,9,13,17)$.

Therefore, with the support of the Department of Energy, the development of techniques for quantitating the sequential biodistribution (pharmacokinetics) of antibodies in patients in vivo was given a high priority $(16,19,25,28,30)$. These techniques are now estallished in our laboratories and represent a unique resource for studies of the type proposed in this continuation application. However, continued work is necessary for improving quantitation of tumor uptake utilizing quantitative S.P.E.C.T. in order to appropriately evaluate the dosimetry of new radiopharmaceuticals, and ultimately develop therapy planning based on the quantitative imaging.

A second area of hign priority was the development and assessment of new radiochemically engineered radioimmunopharmaceuticals. This work involves: (1) development of chemiscry for tightly attaching radionuclides to antibodies [7, 29] so that the radionuclide can be used to trace the antibody in vivo; and (2) documentation in vitro and in vivo of the validity of the rationale $[17,20]$, and, (3) using the methods described above to quantitate radionuclide (anc antibodies) in all or gans and tissues of the patient $[16,19,25,28,30]$. Co-principal investigator Dr. Claude Meares had already led the development of a stable radiometal chelates of In-111 for other proteins, so with his efforts in this area, more stable In-111 Moab radiopharmaceuticals were prepared and tested in vivo, in mice, and in patients. These studies demonstrated that a major improvement in In-111 chelate stability had been achieved by the use of ring stuctures in the chelate moiety, such as the benzyl-EDTA in the In-111 CITC Lym-I radiopharmaceutical used. 
The development of an entirely new chelate was achieved to hold Cu-67 in the antibodychelate in spite of biological intracellular competition. Teta, a tetra-nitro-macrocycle, conceived by Dr. Meares, has been made and studied in vitro and in animals. We now await the funding for this renewal to allow us to increase staff time to be able to compare the pharmacokinetic studies in humans, and to determine whether this radiopharmaceutical is ready to be used for cancer therapy, or whether it may need further improvements in the radiochemistry.

Work has begun on new chelates that might completely control both imaging and therapeutic radionuclides in the same basic structure; i.e., to allow the imaging of In-111 for example, to more accurately predict the biodistribution and metabolic kinetics of the same compound holding the therapeutic Yt-90, (which has no gamma emission to allow easy in vivo follow-up). Work has also begun on linkages would would allow rapid intracellular metabolism and excretion of the bound radiochelate from normal tissues and preliminary data are provided. More staffing is needed for this work and the critical follow-up testing in murine and biochemical test systems and has been requested in this application.

The Section of Radiodiagnosis and Therapy was recently established in recognition of the School and Department of Medicine's commitment to the development of antibodies and antibody-conjugates as vehicles for the treatment and management of patients with cancer. The Section has five professionals whose full-time efforts are committed to research in this area, including the two principal investigator physicians in this Department of Energy prograin, a medical physicist with interests in quantitative imaging and radiation dosimetry, a radiochemist with interests in developing linkers to attach conjugates to antibodies, and a radiopharmacist with special experience in the preparation of pharmaceutical quality antibodies and antibodyconjugates.

This program relates and collaborates actively with physicists and chemists from three cyclotron facilities; i.e., that of our own Crocker Nuclear Laboratory and as well as those of Brookhaven National Laboratory and Los Alamos National Laboratory. This has led to effective methods for production of $\mathrm{Cu}-67$, and work on the production methods for other radionuclides for radioimmunotherapy: $\mathrm{Pb}-201, \mathrm{Hg}-197, \mathrm{Ru}-97, \mathrm{Rh}-101 \mathrm{~m}(5,6,7,27)$.

The use of techniques for absolute quantitation of antibody amounts in organs and tumors of patients provided the insights that led to our abandoning several antibodies in favor of pursuing an antibody (Lym-1) produced against Burkitt's lymphoma. Use of these quantitative imaging techniques in a few patients provided absolute data permitting the conclusion that there was an antibody dose response for Lym-1 and that tumor-targeting could be tripled by administration of a larger amount of Lym-1 antibody (10). These absolute data were used in concert with computer modeling to accurately predict the relationship of blood clearance of antibody 
to the amount of administered antibody, so that it is now possible to "dial in" a desired blood clearance for this antibody $(14,8)$. The resultant optimization of the conditions for use of this antibody conjugated with $\mathrm{I}-131$ has contributed to results from treatment of patients with B-cell lymphoma which some pioneers in the field generously describe as being among the most exciting achieved thus far $(18,31,41)$.

This proposal for ongoing funding will expand this work to therapeutic use of new radiopharmaceuticals developed in this program, and the initiation of similar work in adenocarcinoma.

We have chosen to add to our program, MOAb L-6 developed by the Drs. Hellstrom, because of its well described in vitro and murine in vivo characteristics. Mouse IgG2a MoAb L- 6 identifies a ganglioside that is strongly expressed in many human carcinomas including carcinomas of the lung, breast, colon, and ovary. Iodinated $M \circ A b L-6$ and its $F\left(a b^{\prime}\right)$ and $F a b$ frangments target L-2981 xenografts in nude mice $(33,34,35)$. J-6 monoclonal antibody can kill antigen-positive tumor cells in conjunction with either human lymphocytes (as effector cells) or human serum (as complement), and it can inhibit the outgrowth of L-6 antigenpositive human tumor in nude mice (34). The addition of this antibody to our ongoing work will let us expand our studies from the lymphoma applications to that of the much needed therapy for adenocarcinoma. 
1. Dellardo SJ, Erickson K, Benjamini E, Hines HH, Scibienski R, DeNardo GL: Monoclonal antibodies for radiation therapy of melanoma. In: Nuclear Medicine and Biology I, C. Raynaud (ed.), Pergamon Press, Paris, pp 182-185, 1982.

2. DeNardo SJ, Hines HH, Erickson KL, DeNardo GL: The evaluation of radiolabeled monoclonal antibody parameters necessary for cancer immunoradiotherapy. In: Rational. Basis for Chemotherapy, B.A. Chabner (ed.), Alan R. Liss, Inc., Hew York, pp 379-387, 1983.

3. DeNardo SJ, DeNardo GL: Tumor therapy with radioactive labeled antitumor antibodies. In: Cellular Oncology: New Approaches in Biology, Diagnosis and Treatment, PJ Moloy and G Nicolson (eds), Praeger Press, New York, pp 282-292, 1983.

4. Dellardo SJ, Dellardo GL, Peng J-S, Colcher D: Monoclonal antibody radiopharmaceuticals for cancer radioimmunotherapy. In: Radioimmunoimaging and Radioimmunotherapy, S. Burchiel and R. Rhodes (eds.), Elscvier Publishing LCo., Inc., New York, pp 409-417, 1983.

5. DeNardo SJ, Junnerman JA, DeNardo GL, Lagunas- Solar MC, Cole WC, Meares CF: The choice of radionuclides for radioimmunotherapy. In: Developmental Role of Short lived Radionuclides in Nuclear Medicine Practice, DOE Symposium Series, Washington, D. C. (1982), JW Thiessen and P Pares (eds.), Oak Ridge, Tennessee, Dept. of Energy Technical Information Center, COVIF820523, NTIS pp 401-414, 1985.

6. Dellardo GL, Deilardo SJ: Perspectives on the future of radioimmunodiagnosis and radioimmunotherapy. In: Radioimmunoimaging and iladioimmunotherapy, S. Burchiel and B. Rhodes (eds.), Elsevier Publishing Co., Inc., Now York pp 41-62, 1983.

7. Moi MK, Meares CF, HCCall MJ, Cole UC, Deilardo SJ: Copper chelates as probes of biological systems: Stable copper complexes with a macroncyclic bifunctional chelating agent. Biochemical and Siophys Rescarch Comm, Analytical Biochemistry, 148: $249-253,1995$.

8. Dellardo GL, Raventos A, Hines HII, Scheibe Po, Macey DJ, llayes UT, Deilardo SJ: Requirements for a treatment planning system ior radioimmunotherapy. Int $J$ Rad Onc, Biol and Physics 11:335-343, 1985.

9. Dellardo Gl, Saxe AH, Dellardo Su, Epstein i. Sucy C: Perifusional techniques for screening antibodies (ab) in living tissue. J Huel hed 25:3, $108 ?$ ?

10. Deidardo GL, Deilardo SJ, Peng J-S, UGracy LF, Cardif: RD, Hills SL: Ertects of protein mass on the pharnacoininetios of monocional antivodies. Clin iluo: led $0(95): 37,1984$.

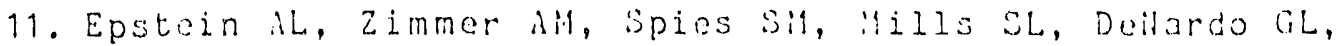
Deilardo SJ: Radioimmonodetection o: human E-cell lymphomas with a radiolabeled turior-specific monoclunal antibody (Lym1). In: Halignant Lymphomas and Hodgisin's Discase: Experimental and Thkerapeutic Advances, F. Cavalli, G. Bonadonna, 4 Rozencqeig (Eds.), Chapeer 14, Martinus Wijhof: Publishing Co., Boston, pp 559-577, 1905. 
12. Adams DA, DeNardo GL, DeNardo SJ, Matson GB, Epstein AL, Bradbury EM: Radioimmunotherapy of human lymphoma in athymic, nude mice ase monitored by $31 \mathrm{p}$ nuclear magnetic resonance. Biochem and Biophys Research Comm 131:1020-1027, 1985.

13. Mills SL, DeNardo SJ, DeNardo GL, Epstein AL, Peng J-S, Colcher D. 1-123 Radiolabeling of monoclonal antibodies for in-vivo procedures. Hybridoma 5:265-275, 1986.

14. Koizumi K, Dellardo GL, DeNardo SJ, Hays MT, Hines HH, Scheibe Po, Peng J-S, Macey DJ, Tonani N, Hisada K: Multicompartmental analysis of the kinetics of radioiodinated monoclonal antibody in patients with cancer. $\mathrm{J}$ Nucl Med 27:1243-1254, 1986.

15. O'Grady, LF, DeNardo GL, Dellardo SJ: Radiolabeled monoclonal. antibodies for the detection of cancer. Am J Physiol Imaging 1:44-53, 1986.

16. Macey DJ, Dellardo GL, DeNardo SJ, Hines HH: A comparison of low and medium energy collimators for SPECT imaging with I123 labeled antibodies. J llucl Med 27:1467-1474, 1986.

17. Cole HC, Dellardo SJ, Meares CF, MCCall MJ, Deilardo GL, Epstein $A L$, O'Brien $H A$, MOI MK: Comparative serum stability of radiochelates for antibody radiopharmaceuticals. J Hucl Med 28:83-90, 1987.

13. Dellardo SJ, Dellardo GL, O'Grady LF, Macey DJ, Mills SL, Epstein AL, Peng J-S, MCGahan JP: Treatment of a patient with B-cell lymphoma by $I-131$ Lym-1 monoclonal antibodies. Intl J Biol Markers 2:49-53, 1937.

19. Deilardo GL, Dellardo SJ, Macey DJ, Mills SL: Quantitative pisarmacokinetics of radiolabeled monoclonal antibodies for imaging and therapy in patients. In: Radiolabeled Honoclonal Antibodies for Imazing and Therapy - Potential, Problems and Prospects. MMTO idvanced Study Institute. S. Srivastava (ed.), Plenum Publishing Co., 1987.

20. Deivardo SJ, Peng J-S, Deilardo GL, Mills SL, Epstein iL: Immunochemical aspects of monoclonal antibodies important for radiopharmaceutical development. liucl hed Biol, 1986.

21. KIeinerman ES, Erickson KL, Scirroit MJ. Fogler WE, and Fidler IJ. Activation of turnoricidal properties in human blood monocytes by liposomes containing lipophilic muramyl tripeptide. Cancer Res. 43:2010-2014, 1933.

22. Thomas, IK and Erickson KL. Lipid modulation or mamary

- tumor cell cytolysis: A direct influence of dictary fats on the effector component of celi-mediated cytotoxieity. J ilatl. Cancer Inst. 74-675-680, 1985

23. Erickson KL. Dietary fat modulation of immune response. Int. J. Immunopharmacol. 8:52?-543, 1986 .

24. Erickson KL, Hcileill CJ and Seibienski RJ. The role of cytophilic antibody in macrophage-mediated cytolysis of melinnoma targets. J ilat1. Cancer Inst. 1937.

25. Vlaccy DJ, Dellardo GL, Deilardo SJ: Absolute quantication of radionuclide uptake by single photon emission computed tomograpiny (SPECT) and a calibration phantom. Radiolocy (submitted)

26. Ryan KP, Dillman RO, Deivardo SJ, Deilardo GL, BeauregardJ, Hagan $P$, Burnett $K$, Rulot $C$, Sobol RE, Bartholomew RK, 
Frincke JH, Birdwell C, Carolo DJ, O'Grady LF, Halpern SE: Imaging of breast cancer metastases using 111 Indium radiolabeled human IgM monoclonal antibody. Radiology (Submitted)

27. Deshpande, S, DeNardo SJ, Meares CF, McCall MJ, Adams GP, Moi MK, DeNardo GL: Copper-67 Labeled Monoclonal Antibody Lym-1, A potential radiopharmaceutical for cancer therapy: Labeling and biodistribution in RAJI tumored mice. (Submitted. J Huc Med.) 1986

28. Macey DJ, DeNardo GL, DeNardo SJ: Comparison of three boundary detection methods for SPECT using compton scattered photons. (In press J.Nuc.Med.)

29. DeNardo SJ, DeNardo GL, Deshpande SV, Adams GP, Macey DJ, Mills SL, Epstein AL, Meares C.F.: The design of a radiolabeled monoclonal antibody for radioimmunodiagnosis and radioimmunotherapy. (Subritted S. Srivastave (ed), Plenum Publishing Co., 1937.

30. Macey DJ, DeNardo SJ, Dellardo GL, Goodnight JK, Unger MW: Uptake of In-111 labeled monoclonal antibody ZME-013 as a function of tumor size in a patient with melanoma. (Submitted J.Physio. Immag.)

31. Dellardo SJ, Dellardo GL, O'Grady, LF, Macey DJ, Mills SL, McGahan JP, Epstein AL. UD Hed. Center, Sacramento, $C \Lambda$ and USC Med.Center, Los Angeles, supported by DOE Grant \#DEFGO3-84ER60233: Radioimmunotherapy of lymphoma with fractionated I-131 Lym-1: Phase I/II study. J.Nuc.Med., Abstract, June 1987.

32. Meares CF, McCall MJ, Deshpande SV, Deilardo SJ, Goodwin DA: Chelate radiochemistry: cleavable linkers lead to altered levels of radioactivity in the liver. (In press J. Nuc.Med.)

33. Hellstrom I, Horn D, Linsley P, 3ronn JP, Brankovan V, Hellstron KE: Honoclonal mouse antibodies raised against human lung carcinoma. Cancer Research 46.3917-3923, Aug. 1986.

34. Hellstrom I, Beaumier PL, Hellstrom KE: Antitumor effects of L6, an IgG2a antibody that reacts with most human carcinomas. Proc. Nat1. Acad. Sci.USA 33, 7059-7063, Sept.1986 iledical sciencos.

35. Hellstron I, Helistrom KE, Yein iY: Int J Cancer 27: 281-235, 1981.

36.lloughton NN, Mintzer D, Cordon-Cardo C, Welt S, Fliegel 3 , Vadham S, Carswell E, Malananed :iR, Oetzgen HF: Proc ilat

- Acad Sci USA 82: 1242-1240, 1955.

37 Herlyn D, Lubeck M, Steplewski Z, ronprowsik H: UCLd Symposia on Holecular and Collular Biolugy 27: 165-172, 1935.

39. Reisfeld RA, Schultz G, Cheresh DA: UCLA Symposia on Molecular and Cellular Biology 27: 173-1:1, 1935.

39order SE, Klein JL, Leichner. PK, Frinase J, Lollo C, Carlo DJ: Int 11 Radiation Oncology Biol Pl:ys 1:: 2î-231, 1936.

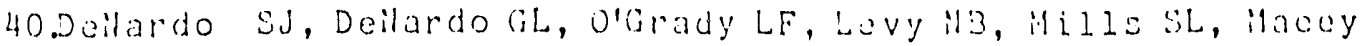
DJ, HCG ahan JP, Hiller CH, Epacein ML, Hoares CF: Antibody, Immunoconjugates and Radiopharinceuiicals, 1987.

41. Delvardo SJ, Dellardo GL, O'Grady LF, Levy NB, Mills SL, Nacey DJ, N.TcGahan JP, Miller CH, Epstein AL. Pilot studies of radioimmunotherapy of $B$ cell 1ymphoma and leukemia using I-131 Lym-1 monoclonal antibody. Antibody, Immunoconjugates, and Radiopharmaceuticals, Mary Ann I,iebert, Inc., publishers. 
S. J. DeNardo, G. L. DeNardo, L. F. O'Grady, D. J. Macey, S. L. Mills, J. P. McGahan, A. L. Epstein, J. P. McGahan. U. C. Medical Center, Sacramento CA and U. S. C. Medical Center, Los Angeles. Supported by CA. DOE Grant \#DEFG03-84ER60233

In order to develop ef fective radioimmunotherapy for patients with B-cell lymphoma we initiated a Phase I/II trial of intravenously injected I-131 Lym-1, an IgG2a $\mathrm{MAb}$ produced against African Burkitt's lymphoma, and labeled at one I/Ab with immunoreactivity greater than $80 \%$. Ten patients with aggressive lymphoma who had failed standard $R x$ have been accessed, and greater than 40 doses of I-131 Lym-1 have been delivered, at 2 to 6 week intervals, 2 to 9 doses per patient, up to $300 \mathrm{mCi}$. Each treatment consisted of $5 \mathrm{mg}$ unlabeled Lym-1 immediately prior to 30-60 mCi of I-131 Lym-1 (3-6 mg). Tumor volumes were followed by $C T$ and caliper measurements. Seven of ten patients had objective tumor regression of greater than $30 \%$, and three of these patients greater than 70\% tumor regression. Three patients expected to live less than 6 months are clinically well 6-20 months after aocess to the protoool. No toxicity occurred; one patient had transient myalgia and nausea temporaliy related to tumor response. There was no change in liver or renal functions. One patient developed HAllA after three doses.

Calculated tumor dose has ranged from 10-200 rads per $\mathrm{mCi}$, whole body dose from 0.3 - 0.5 rads per $\mathrm{mCi}$, mar ow dose from $0.5-1.0$ rads per $\mathrm{mCi}$. The lack of toxicity aud the documented tumor response suggest this to be an effective approach for treating Bcell lymphuma.

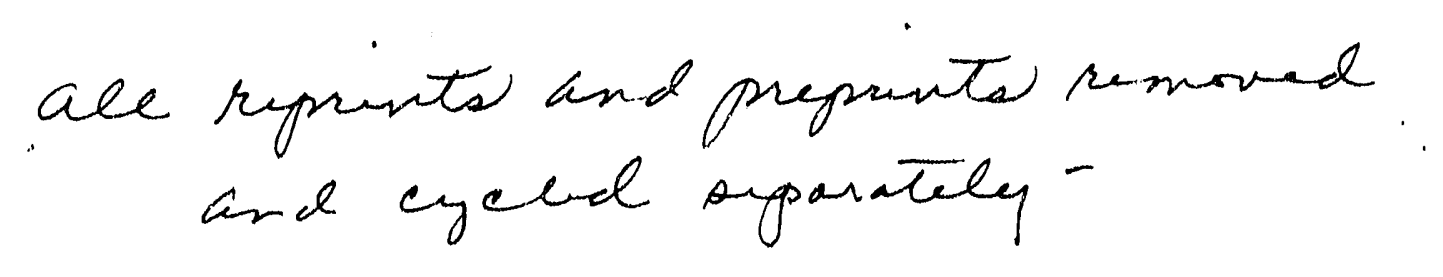


Degrees received:<smiles></smiles>

Postdoctoral fellows:
Cladio Zinelli, Ph.D., M.S. Physics 1985

Kitty Chelton, M.S., Biophysics 1985

Scott Schubert, M.S., Immunology 1987

David Treague, Ph.D., Immunology

Greg Adams, Ph.D. candidate, Immunology

Asim Amin, M. D., Ph.D. candidate, Immunology

Min Moi, Ph.D. Candidate, Chemistry

Khanh Doan Do, M.D. Candidate, 1987

William Cole, Rh.D., radiopharmacy, 1983-85

Shrikant Deshpande, Ph.D., Chemist, 1986- current

Kiyoshi Koj.zumi, M.D., Fellowship, 1985-86

Wen Young, M.D., Fellowship, 1986-87

Cheng-garg Zhang, M.D., visiting Professor, 1987-89

Amalia Nogueira, visiting Professor, 1987 


\section{PROGRAM GOAL}

TO ANSWER THE FUNDAMENTAL SCIENTIFIC QUESTIONS FOR THE DEVELOPMENT OF AN EFFECTIVE APPROACH FOR DELIVERING RADIATION THERAPY TO CANCER ON ANTIBODY-BASED RADIOPHARMACEUTICALS.

\section{OBJECTIVES:}

\subsection{TO DEVELOP RADIOIMMUNOPHARMACEUTICALS FOR CANCER THERAPY}

1.1 lo determine radionuclide choices appropriate for therapy to solid tumors, to infiltrating bone marrow tumor, and to leukemic or intracavitary single cell disease.

1.2 To develop and test antibody radiopharmaceuticals from new radiochelates designed to completely control the chosen radiometals in vivo.

1.21 To develop a macrocycle family that will completely control both IN-111 and YT-90.

1.22 To test the multiple macrocycles for their ability to bind desirable therapeutic radionetals.

1.23 To improve the chelate developed for CU-67 if humans studied prove this necessary.

1.3 To develop more optimal chelate-antibody attachments.

1.31. To determine the most effective linkage for rapid clearance of the radiochelate from normal or sans while maintaining retention of the radiochelate antibody on the tumor membranes.

1.32 To determine that chosen chelate-antibody attachments do not interfere with the immunologic and biologic (cell activation or complement activation) activity of the radiochelate-linked antibodies.

2.00 TO DEVELOP THERAPY PLANNING BASED ON QUANTITATIVE IMAGING.

2.1 To utilize quantitative imaging to evaluate selected radiopharmaceuticals.

2.11 To cbtain quanticative pharmacokinetics and tumor uptake information in a mode which allows statistical evaluation of the validity of the information about a radiopharmaceutical from a few patient studies. 
2.2 To utilize planar quantitative imagine techniques that we have developed to obtain radiopharmacokinetio data on serial therapy doses in patients.

2.3 To utilize this information to calculate the radiation dose to the patient, normal organs, and tumors for each therapy dose.

2.4 To develop S.P.E.C.T. quantitative methods to determine more accurate normal organ uptake and tumor uptake, particularly in tumors deep in the body.

2.5 To correlate the projected therapy dosimetry with that actually observed / correlate with information from microdosimeters implanted in patient tumors, autoradiography of biopsies, and in vitro quantitation of the radioactivity.

2.6 To determine the most effective manner to utilize this approach to plan a treatment course and to predict response.

3.00 TO DEVELOP METHODS TO ENHANCE DELIVERY OF THE RADIOIMMUNOPHARMACEUTICAL TO THE TUMOR.

3.1 To increase tumor vessel permeability.

3.11 Utilization of dose schedule and dose rate to enhance the vascular permeability for the follow-up doses.

3.12 Pre-irradiation with external beam or specifically timed predose of radiolabeled antibody.

3.13 Pretreatment or co-treatment of patients with I.L,-2 and antibody.

3.14 Pretreatment of co-treatment of patients with toxins and antibody.

3.2 To increase tumor bloodflow.

3.21 See above.

3.3 To increase tumor antigen expression.

3.31 Interferon pretreatment and/or co-treatment.

4.00. TO STUDY THE BIOKINETICS AND THERAPEUTIC POTENTIAL OF THE NEWLY DEVELOPED RADIOPHARMACEUTICALS.

4.1 In animals (kinetics and chosen therapeutic trials).

4.2 In patients (kinetics and chosen therapeutic trials). 
4.3 Correlation of the therapeutic index of radiopharmaceutioals prepared with differences in the chemistry of attachment.

5.00 TO CORRELATE MACRO AND MICRODOSUMETRIC INFORMATION TO THE TUMOR RESPONSE RATE IN ANIMALS AND PATIENTS.

5.1 To use miorodosimeters and autoradiography in animal therapy protocols and in patient quantitative pharmacokinetic/therapy feasibility protocols.

5.11 To determine the dose rate and variation and intra tumor.

5.12 To determine the correlation with mechanisms utilized to enhance delivery.

5.13 To correlate microdosimetry with histology and tumor response.

5.2 To determine the effects of dose rate and dose fractionation on tumor uptake and on tumor response in animals and in patients.

6.00 MONOCLONAL/TUMOR TARGET SELECTION.

6.1 To utilize the Moabs LYM-1 and LYM-2 antibodies in the lymphoma/leukemia studies.

6.2 To utilize the Moab L-6 to study the delivery of therapy (per the above objectives) to breast cancer. 
I. To develop radioimmunopharmaceuticals for cancer therapy.

\section{Progress in Chelate Chemistry}

$\mathrm{Cu}-67$ is one of the most promising radiometals for radioimmunotherapy. It has a 61.5 hour physical half-life which is well matched to the residence time of a typical antibody on the tumor; $\mathrm{Cu}-67$ releases abundant beta particles as well as a moderate abundance of 93 and $184 \mathrm{kev}$ gamma emissions. These gamma emissions permit radiation dosimetry to be predicted from the information obtained from quantitative imaging studies on pre-therapy dozes $n \mathrm{f} \mathrm{Cu}-67$. This pre-therapy imaging and kinetics, followed by similar pharmacokinetics of the actual therapy doses, allow treatment planning and on-going verification of that planning with actual dosimetric information on the radiation delivered.

A major consideration in order for a metal chelate to be useful for radiodiagnosis and therapy is its kinetic inertness; that is, the rate of loss of radioactive metal ion from the chelate to other metal binding molecules in the body must be slow. In general, the radiolabeled MoAb is administered intravenously. Blood contains substantial concentrations of metal binding proteins such as transferrin and albumin (Note that the concentration of albumin in serum is several orders of magnitude higher than that of the chelate in blood under clinical cunditions)(White et al., 1968; Ritzman \& Daniels, 1982). When the radiophar maceutical contains 111 In, the serum protein transferrin, well known for its removal of trivalent iron from chelates, is a dominant factor (Hosain et al., 1969). For ${ }^{67} \mathrm{Cu}$, albumin is most important (Sarkar et al., 1983). Furthermore, while the composition of the intracellular spaces where antibodies may be transported is less well known, metal-binding molecules are certain to be found there as well.

Many metallic elements are potentially useful for medical applications, in conjunction with antibodies. Besides ${ }^{111}$ In and ${ }^{67} \mathrm{Cu},{ }^{90} \mathrm{Y}$ is a prominent radionuclide, and there is a list of other possibilities (DeNardo et al., 1985). The chelating agents we synthesize are tested with $111 \mathrm{In}, 67 \mathrm{Cu}$, and $90 \mathrm{Y}$ at a minimum.

\section{Copper Macrocycles}

In order to use Cu- 67 for radioimmunotherapy it must be stably chelated to the monoclonal antibody. Serum stability studies of copper chelates of EDTA and DTPA have indicated that copper is readily transferred from these chelates to serum albumin (Cole et al., 1987). With DOE support, we recently reported the synthesis and characterization of a new macrocycle (6-pnitrobenzyl-TETA) (Moi et al, 1985) which forms a copper chelate that remains stable in serum for several days (Cole et al., 1987). 
We wish to vary the chelate structure over a limited range, to study the dependence of chelate stability on ring size. To this end, we prepared the 16membered macrocycle nitrobenzyl-HETA by a route analogous to that used for nitrobenz 1-TETA (Moi et al, 1985). Preliminary experiments indicate that nitrobenzyl-HETA retains copper ions poorly in serum under physiological conditions, losing copper to albumin at a rate comparable to copper-EDTA and-DTPA. The 12-membered macrocycle nitrobenzyl-DOTA cannot be synthesized by the route used for TETA and HETA, because DOTA does not possess a three-carbon chain. We are trying routes based on condensation of nitrobenzyl-triethylenetetramine with appropriate 2-carbon esters. The reaction of tetra- $\mathrm{N}$-tosyl-nitrobenzyl-triethylenetetramine with di-0-tosyl-ethylene glycol under Richman-Atkins conditions did not produce the desired product in isolable quantity. Nor did the reaction of nitrobenzyltriethylenetetramine with glyoxal or with diethyl oxalate, even in the presence of nickel(II). Currently, we are investigating approaches based on peptides. It is important to prepare and study the DOTA chelator, as its sualiter ring size may confer added rigidity and stability to its metal complexes.

We have also developed smooth procedures for radiolabeling the antibodychelator conjugate of TETA with Lym-1 with ${ }^{67} \mathrm{Cu}^{++}$. This requires the use of a spacer arm (linker) as described below and outlined in Figure 1.

\section{Preparation of $\mathrm{p}$-A minobenzy 1 TETA}

p-Nitrobenzyl TETA ( $55.1 \mathrm{mg}, 97.1 \mathrm{uM}$ ) was dissolved in $20 \mathrm{ml}$ of distilled water and the $\mathrm{pH}$ was adjusted to 11.5 using $2 \mathrm{M} \mathrm{NaOH}$. The solution was cooled in an ice bath and $1 \mathrm{mg}$ palladium on powdered charcoal (10\% catalyst) was added. The mixture was placed under hydrozen atmosphere and temperature was maintained at $0{ }^{\circ} \mathrm{C}$. The appearance of a faint greenish color was noted during the course of the reaction. After sir hours, the reaction mixture was neutralized and filtered through a nylon 66 Millipore filter. The filtrate was analyzed for the presence of aromatic amines by use of the fluorescamine test. After lyophilization, the residue yielded $45.2 \mathrm{mg}$ p-aminobenzyl TETA. Based on titration with Co-57, the metal binding capacity of this product was $86.7 \%$.

\section{Preparation of $\mathrm{p}$-Bromoacetamidobenzyl TETA (BAT)}

p-A minobenzyl-TETA (45.2 $\mathrm{mg}, 84.2 \mathrm{uM}$ ) was dissolved in $2 \mathrm{ml}$ of distilled water and the $\mathrm{pH}$ was adjusted to 6.5 using $2 \mathrm{M} \mathrm{HCl}$. 50 ul of bromoacetyl bromide was then added in $10 \mathrm{ul}$ aliquots. Completion of the reaction was determined by fluorescamine for the absence of aromatic amine groups and p-nitrobenzyl pyridine (NBP) for the presence of alkyl bromide. After complete addition of bromoacetyl bromide, the reaction mixture was washed 

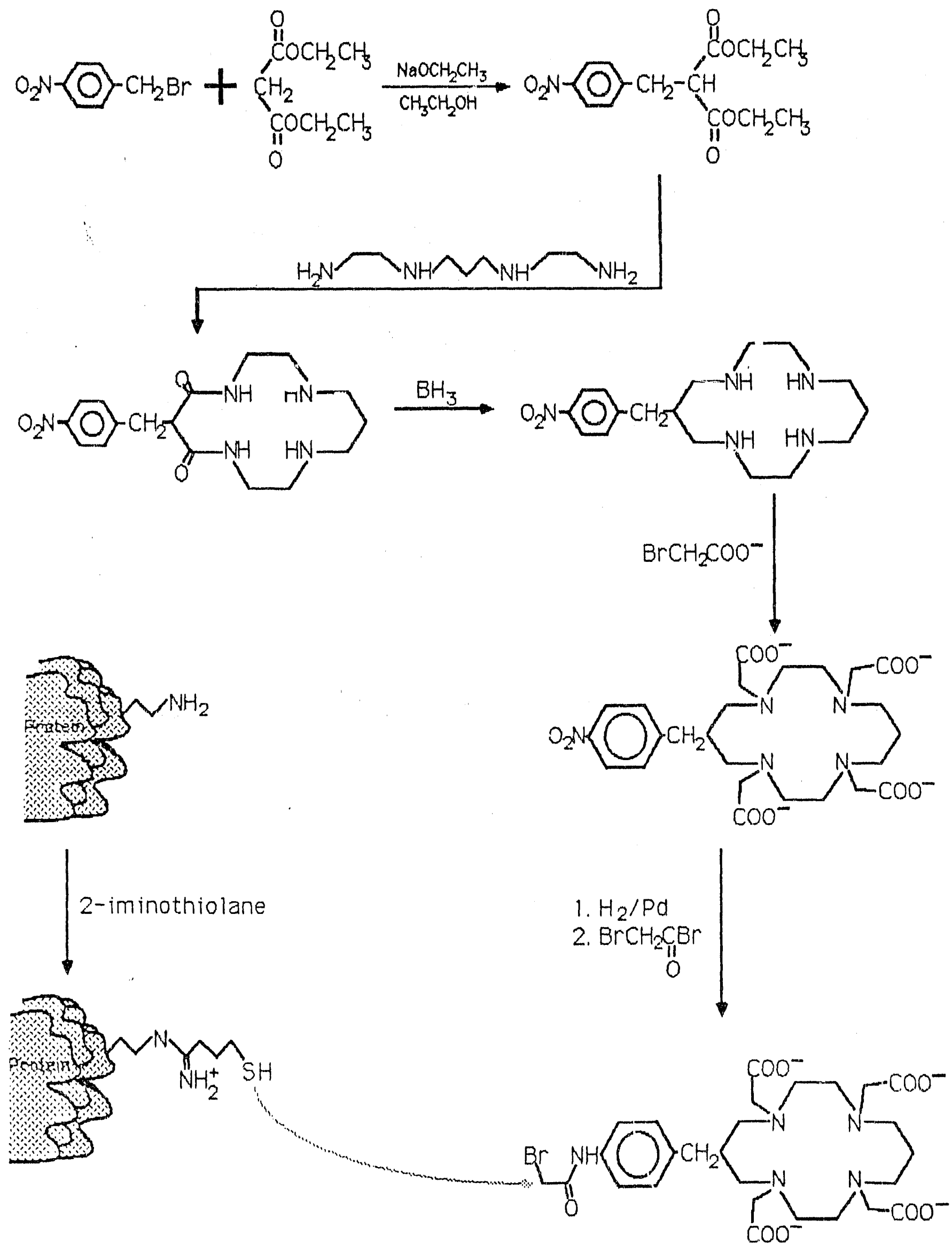

Figure 1. Synthesis \& Conjugation of TETA 
with ether $(4 \times 1.4 \mathrm{ml})$ and lyophillized. The product weighed $45.8 \mathrm{mg}$ and the metal binding capacity was $81.8 \%$.

Synthesis of Antibody Clelator Coniugate (Lym-1-2IT-BAT)

$20 \mathrm{mM} 2$-iminothiolane (2IT) solution was prepared by dissolving $2.7 \mathrm{mg}$ in $1 \mathrm{ml}$ of $50 \mathrm{mM}$ triethanolamine at $\mathrm{pH}$ 8.6. To $1 \mathrm{mg} \mathrm{Lym}-1$ in $65 \mathrm{ul} 100 \mathrm{mM}$ sodium phosphate buffer at $\mathrm{pH} 8,32$ ul of freshly prepared 2-iminothiolane solution and $3.2 \mathrm{ul} 2$-mercaptoethanol was added. The resulting solution was vortex-mixed for 30 seconds and incubated at $4^{\circ} \mathrm{C}$ for 30 minutes. The centrifuged column procedure (G-50-80, $0.1 \mathrm{M}$ sodium phosphate buffer, $\mathrm{pH}$ 8 ) was used to remove small molecules, including unreacted 2 -iminothiolane and 2-mercaptoethanol. The effluent containing the protein was directly collected in a metal-free microcentrifuge tube containing 25 ul of $11 \mathrm{mM}$ BAT in $0.1 \mathrm{M}$ sodium phosphate buffer at $\mathrm{pH} 8$. Argon gas was gently blown on the solution and the cap of the tube was closed to maintain an inert atmosphere. The reaction mirture was incubated at $4{ }^{\circ} \mathrm{C}$ overnight. Iodoacetamide $(1 \mathrm{mg})$ was adred at room temperature to alkylate unreacted suifhydryls on the protein. Aiter 30 minutes, the protein chelator conjugate (Lym-1-2IT-BAT) was separated from lower molecular weight compounds by the centrifuged column method, which also changed the buffer to $0.1 \mathrm{M}$ citrate, $\mathrm{pH} 8$. The protein concentration was determined by measuring ultraviolet absorbance at $280 \mathrm{~nm}$.

Quantitating the Number of Bound Chelating Groups.

A nonradioactive sample of pure cobalt metal vas weighed to four significant figures, dissolved in $6 \mathrm{M} \mathrm{HCl}$ at $60{ }^{\circ} \mathrm{C}$ and then diluted with a known amount of deionized water in a volumetric flask. A measured volume of this solution was again diluted in a volu-metric flask using $0.06 \mathrm{M} \mathrm{HCl}$ to obtain $500 \mathrm{uM}$ in $\mathrm{Co}^{2+}$ (exact value accurately calculated). A $500 \mathrm{ul} \mathrm{amount}$ of this solution was added to approximately $0.01 \mathrm{mCi}$ of dry carrier-free Co57 to yield a solution with radioactivity concentration greater than 5000 CPM per $u l$ and an accurately known concentration of $\mathrm{Co}^{2+}$.

Ten ul of protein conjugate solution was mixed with 10 ul of $0.1 \mathrm{M}$ sodium phosphate buffer at $\mathrm{pH} 8.5$ and $10 \mathrm{ul}$ of standardized ${ }^{57} \mathrm{CoCl}_{2}$ solution. After 20 minutes, 10 ul of $10 \mathrm{mM}$ EDTA and $60 \mathrm{ul} 0.1 \mathrm{M}$ sodium phosphate buffer at $\mathrm{pH} 8.5$ were added. Co- 57 !abeled protein was separated from the lower molecular weight species by the centrifuged column method. The column and the effluent were separately counted in a gamma well counter. The concentration of protein bound chelators available for metal binding was calculated as described by Moi et al (1985).

Labeling Antibody-chelator Conjugate (Lym-1-2IT-BAT) with Cu-67. 
7.2 $\mathrm{mCi}$ of $\mathrm{Cu}-67$ solution in $2 \mathrm{M} \mathrm{HCl}$, purified by AG-1 anion exchange chromatography, was evaporated to dryness in a metal free plastic test tube using a heat lamp and a gentle flow of nitrogen gas. 79 ul of protein conjugate solution ( 600 ug protein) in $0.1 \mathrm{M}$ citrate buffer at pH 8 was then added and incubated at room temperature for one hour with occasional vortex mixing. Ten ul of $10 \mathrm{mM}$ EDTA solution and $11 \mathrm{ul}$ citrate buffer $(0.1$ $\mathrm{M}, \mathrm{pH} 8$ ) was added to the reaction mixture to chelate $\mathrm{Cu}-67$ that had not been bound to chelating groups on the antibody. After two minutes labeled protein was separated from lower molecular weight compounds by the centrifuged column procedure into $0.1 \mathrm{M}$ sodium phosphate buffer at $\mathrm{pH} 7.4$. Reaction yield was calculated from the TLC of the reaction mixture after addition of EDTA.

To check for nonspecifically bound $\mathrm{Cu}-67$ on the protein conjugate, $1 \mathrm{ul}$ of radiopharmaceutical was mixed with 2 ul of $1 \mathrm{mM}$ EDTA. incubated at room temperature for ten minutes and a TLC was performed.

\section{Benzy1-EDTA compared to Benzyl-DTPA for 11 In Chelation.}

The rate and extent of metal loss in vivohas a fundamental bearing on the choice of effective methods to use chelates in diagnosis or therapy. For example, in cont ast to radioiodinated monoclonal antibodies, relatively high levels of 111 In are of ten observed in the liver, and evidence from animal models indicates that ${ }^{111}$ In is lost from DTPA in the liver (Mathias \& Welch, 1987). This would appear to limit alternatives for changing the biological distribution of 111 In (or ${ }^{67} \mathrm{Cu}$ ) labeled antibodies. However, we have used a specific anti-benzyl-EDTA-indium antibody (developed by Reardan et al., 1985) to show that practically a't of the indium appearing in the urine of human patients (or mice) injecied with benzyl-EDTA-111 In labeled monoclonal antibodies is still in the original chelated form. Most of the excreted radioactivity appears in the urine. Also, preliminary evidence indicates that the use of benzyl-EDTA-111 In labeled monoclonal antibodies can lead to significantly faster clearance of indium from the body than is observed when DTPA-111 In is the label. In a small number of lymphoma patients imaged with the antibody Lym 1 labeled with the 111 In chelate of the reagent CITC (Figure 2), the typical half-life observed for clearance of radioactivity from the body is a few days (SJD et al., work in progress).

In the past, we have developed general, versatile synthetic procedures leading to a number of different chelating groups (Meares et al., 1982; Meares et al., 1984). In order to determine whether the benzyl-EDTA chelators we normally use with ${ }^{11} 1$ In are less stable than benzyl-DTPA 

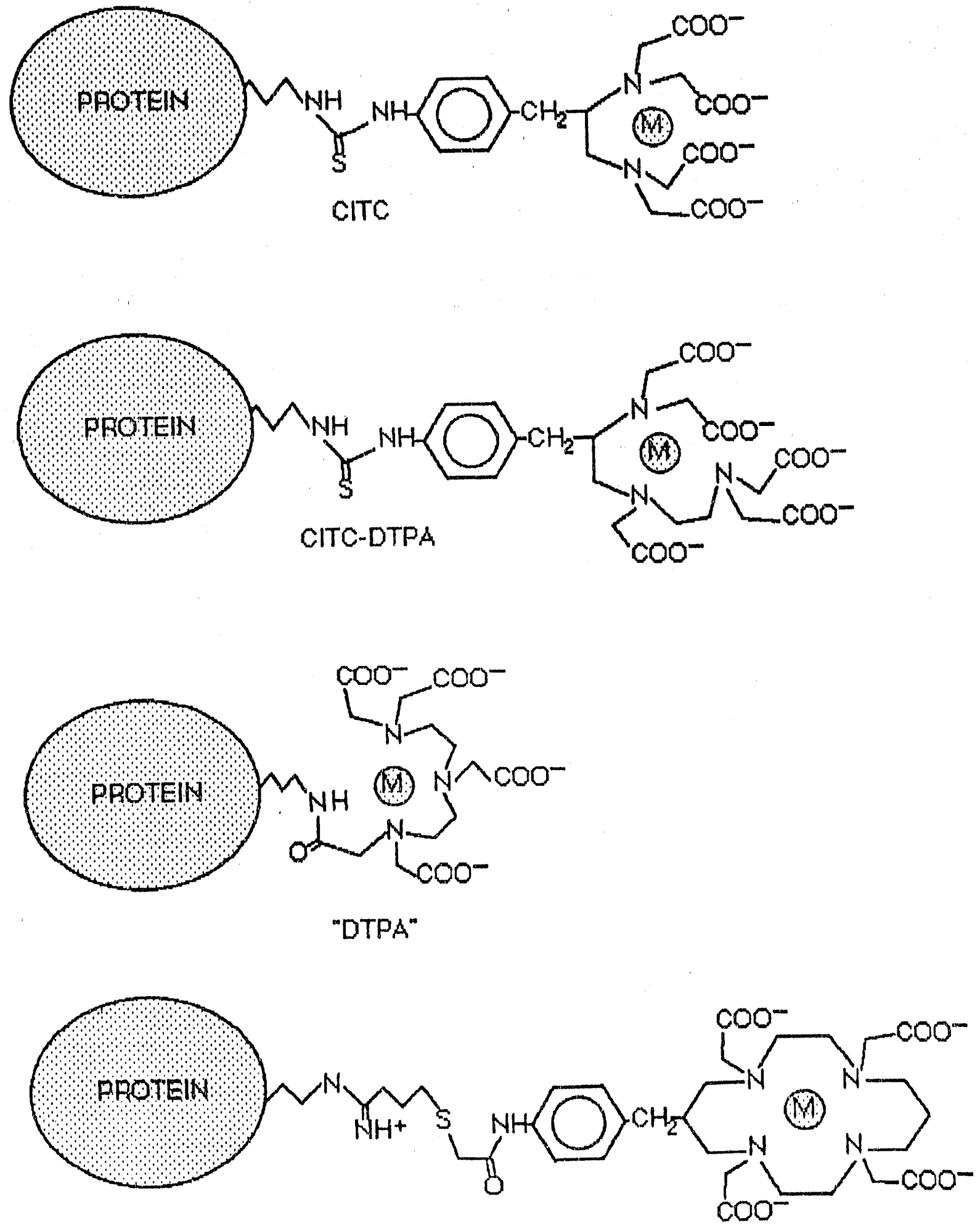

2-IT-BAT

Figure 2. Chelate Structures. 
chelators (Figure 2) under physiological conditions, as has recently been suggested (Brechbiel et al., 1986), we compared the two under precisely controlled conditions in vitroin human serum.

p-nitrobenzyl-EDTA was prepared according to DeRiemer et al. (1981); pisothiocyanatobenzyl-EDTA (CITC) was prepared according to Meares et al. (1984) p-nitrobenzyl-DTPA was prepared by the same methodology as pnitrobenzyl-EDTA, except that ethylenediamine was substituted for ammonia in the conversion of $p$-nitrophenylalanine methyl ester to the amide (Meares et al., 1982). Thus $11.4 \mathrm{~mL}$ (171 m mol, 25X excess) of ethylenediamine was added to a solution of $1.79 \mathrm{~g}(6.86 \mathrm{mmol})$ of $\mathrm{L}-\mathrm{p}$-nitrophenylalanine methyl ester hydrochloride in $70 \mathrm{~mL}$ of $\mathrm{CH}_{3} \mathrm{OH}$. After 4 days at room temperature, the reaction mixture no longer contained the starting ester, as shown by TLC (Si gel/plastic; $95 \%$ aq EtOH/7\% aq NH3; 4/1, v/v; p-nitrophenylalanine methyl ester, $R_{f} 0.78 ; p$-nitrophenylalanine $\beta$-aminoethyl amide, $R_{f} 0.35$; ethylenediamine, $R_{f} 0.1$ ). Methanol was removed from the solution under reduced pressure, leaving $10-15 \mathrm{~mL}$ of yellow oil. Water $(25 \mathrm{~mL})$ and tetrahydrofuran $(100 \mathrm{~mL})$ were added to the residue. The product was isolated from the tetrahydrof uran layer after a series of extractions and back-extractions to remove the excess ethylenediamine. After removal of the tetrahydrofuran under reduced pressure, the product was taken up in $\mathrm{H}_{2} \mathrm{O}$ and lyophilized to a brown residue $(2.0 \mathrm{~g})$, which gave a single ninhydrinpositive spot on TLC $\left(R_{f} 0.35\right)$. The crude amide was reduced with $\mathrm{BH}_{3}$ to the triamine, and carboxymethylated with bromoacetate to form the pentaacetate by the methods of Yeh et al. (1979) It was purified by AG-1 anion-exchange chromatography with a gradient of for mic acid. Yield of $p$ nitrobenzyl-DTPA: $804 \mathrm{mg}, 1.52 \mathrm{mmol}, 22 \%$ based on nitrophenylalanine. ${ }^{1} \mathrm{H}$ $\operatorname{NMR}\left(300 \mathrm{MHz}, \mathrm{D}_{2} \mathrm{O}, \mathrm{pH} 11.4\right)$ : aromatic aa'bb' (4H) at $\delta 8.2$ and 7.5 ; $-\mathrm{CH}_{2}-$ $\mathrm{COO}^{-}(10 \mathrm{H})$ at $3.0<\delta<3.35$; other aliphatic $(9 \mathrm{H})$ at $2.1<\delta<3.0$.

Reduction of the aromatic nitro to an amine and formation of the isothiocyanate were by the methods of Meares et al. (1984)

The monoclonal antibody Lym-1 employed in these investigations was prepared by Damon Biotech (Needham Heights, MA 02194, Encapcel Murine Monoclonal Antibody, Lot No.3-171-860818). It was further purified by protein-A affinity column chromatography.prior to use. Protein-ASepharose-CL4B, received from Pharmacia, was swollen in sodium phosphate buffer $(0.1 \mathrm{M}, \mathrm{pH} 7.0)$ for $6 \mathrm{hr}$. The swollen gel was packed into a $1.5 \mathrm{~cm}$ wide column to a height of $3.3 \mathrm{~cm}$, and washed thoroughly with $\mathrm{pH} 7.0$ phosphate buffer. The adsorbed contaminants, if any, in the Protein A column were removed by washing with $8 \mathrm{ml}$ of $\mathrm{pH} 3.0$ buffer (prepared by mixing 20.6 volumes of $0.2 \mathrm{M} \mathrm{Na}_{2} \mathrm{HPO}_{4}$ and 79.4 volumes of $0.1 \mathrm{M}$ citric 
acid). The column was again washed with $\mathrm{pH} 7.0$ phosphate buffer. $40 \mathrm{mg}$ of the monoclonal antibody Lym-1 in $10 \mathrm{ml}$ of $\mathrm{pH} 7.0$ buffer was applied to the column. The antibody was eluted from the column using $30 \mathrm{ml}$ of $\mathrm{pH} 5.5$ phosphate/citrate buffer, prepared by mixing 55.8 volumes of $0.2 \mathrm{M}$ $\mathrm{Na}_{2} \mathrm{HPO}_{4}$ and 44.2 volumes of $0.1 \mathrm{M}$ citric acid, (DeNardo et al., 1987a). The Lym-1 fractions were pooled together, concentrated using Centricon (Amicon) microconcentrators, and quickly frozen in liquid nitrogen and then stored at $-80^{\circ} \mathrm{C}$. The concentration of the monoclonal antibody was determined by measuring the absorbance at $280 \mathrm{~nm}\left(E^{1 \%} 280=14\right)$ using a Gilford spectrophotometer.

Conjugation of CITC or CITC-DTPA to LYm-1.

In the bifunctional chelating agents employed (viz. CITC, CITC-DTPA) the following methodology was employed to conjugate the chelating agent to the antibody. Lym-1 ( $\approx 0.1 \mathrm{~mL}$ of $0.1 \mathrm{mM}$ solution) and CITC or CITC-DTPA (20$30 \mathrm{uL}$ of $15 \mathrm{mM}$ solution) were combined in phosphate buffer $(0.1 \mathrm{M}$ phosphate buffer, $\mathrm{pH} \mathrm{9.0)}$ and the final $\mathrm{pH}$ of the reaction mixture was adjusted to $\mathrm{pH} 9.0$. Then the reaction mixture was incubated at $37^{\circ} \mathrm{C}$ in a water bath for $2 \mathrm{hr}$.

At the end, the unreacted CITC or CITC-DTPA (that was not attached to Lym1) was removed by passing the reaction mixture through a spin column containing a Sephadex G-50-80 gel filtration resin (Sigma). The MoAbchelate conjugate was collected in the effluent. This method is routinely employed to remove the low-molecular weight compounds from the antibody. Details of this method have been described elsewhere. 22

Conjugation of DTPA anhydride. to Lym-1

The procedure employed was essentially that of Eckelman et al. ${ }^{23}$. A solution of $100 \mathrm{nmol}$ DTPA anhydride in $5 \mu \mathrm{l}$ chloroform was dried into a thin film along the walls of an eppendorf tube using dry nitrogen. $100 \mu \mathrm{l}$ of $0.1 \mathrm{mM}$ Lym-1 solution in phosphate buffer was added to it (DTPA:Lym-1 10:1) After about $5 \mathrm{~min}$ at room temperature, the reaction mixture was subjected to spin column gel filtration chromatography, using a G50-80 resin as described earlier.

Radiolabeling of MoAb-chelate conjugate

Stock solutions:

Lym-1-CITC

$50 \mu \mathrm{M} \mathrm{Ab}, \quad 2.5 \mathrm{chel} / \mathrm{Ab}$

Lym-1-CITC-DTPA

$70 \mu \mathrm{M} \mathrm{Ab}, \quad 1.6 \mathrm{chel} / \mathrm{Ab}$

Lym-1-DTPA

50 $\mu \mathrm{M} \mathrm{Ab}, \quad 3.0 \mathrm{chel} / \mathrm{Ab}$ 
Radiolabeling was performed in $0.1 \mathrm{M}$ ammonium citrate buffer, $\mathrm{pH} 5.0$, in all cases, as $111 \mathrm{InCl} 3$ readily hydrolyzes at high $\mathrm{pH}$ (Meares, 1986).

Normally the MoAb-Chelate conjugate concentration is kept $>10 \mu \mathrm{M}$, in $0.1 \mathrm{M}$ ammonium citrate buffer, pH 5.3. Dry $111 \mathrm{InCl}_{3}$ was dissolved in $0.1 \mathrm{M}$ ammonium citrate buffer, $\mathrm{pH} 5.0$, and appropriate volumes are mixed so that the final chelator concentration was $10 \mu \mathrm{M}$. Typically $2 \mu 1{ }^{111} \operatorname{InCl}_{3}$ added to 8 $\mu l$ of MoAb soln. $\mathrm{pH}$ of the reaction mixture was measured with indicator paper, and adjusted to $\approx 5.0$ if necessary. The reaction mixture was incubated at room temperature $\approx 1 \mathrm{hr}$. At this time, $10 \mu \mathrm{l}$ of $0.1 \mathrm{M}$ phosphate buffer ( $\mathrm{pH}$ 7) was added, then $2.2 \mu 114 \mathrm{mM}$ EDTA solution was added to the reaction mixture to convert free 111 In to 111 In-EDTA. Under these conditions EDTA does not remove the 111 In that is bound to the antibody through the $\mathrm{BCA}$. The reaction mixture was incubated at room temperature for about $5 \mathrm{~min}$. At the end, $100 \mu \mathrm{l}$ of $\mathrm{pH} 7 \mathrm{phosphate}$ buffer was added, and the reaction mixture was subjected to spin column gel filtration chromatography. The 111 In-EDTA was retained by the column and the radiolabeled MoAb-chelate conjugate is obtained in the effluent. Best results were obtained when the spin column was repeated twice more to eliminate traces of unbound indium. The last colunu was in saline; earlier ones in $0.1 \mathrm{M}$ phosphate $\mathrm{pH} 7$. ALL the 111 In was then retained on the Pro-A column, showing that all of it was bound to MoAb.

The presence of free $111 \mathrm{In}$ will lead to formation of $111 \mathrm{In}$-Transferrin. To avoid this, a TLC analysis was employed to check the results. $1 \mu 1$ In-MoAb applied to TLC. $111 \mathrm{InCl} 3$ and $111 \mathrm{In}-\mathrm{MoAb}$ chelate remains at the origin whereas 111 In-EDTA moves to a Rf 0.8 . In this experiment, the radioactivity at $R f$ values $0-0.2,0.2-0.4,0.4-1.0$ were measured by cutting the TLC into three different strips and counting the radioactivity in each portion.

The percentage of 111 In present intact as the radiolabeled MoAb was determined by a protein $\mathrm{A}$ affinity column chromatography. Lym-1 is an IgG2a antibody which binds protein $\mathrm{A}$ at $\mathrm{pH}$ 7-8. Under same conditions $111 \mathrm{In}$-transferrin or $111 \mathrm{InCl} 3$ do not bind protein $\mathrm{A}$. Hence by subjecting a serum sample containing the radiolabeled MoAb to a protein A column chromatography and estimating the radioactivity (here 111 In) of the column and the effluent fractions, one can determine the percentage of 111 In present as 111 In-MoAb. When a buffer solution of $\mathrm{pH} 5.5$ is used Lym-1 protein comes off the column. By this method one can further confirm the percentage of $111 \mathrm{In}-\mathrm{MoAb}$ present intact in the serum. Results are given in the figure below. 


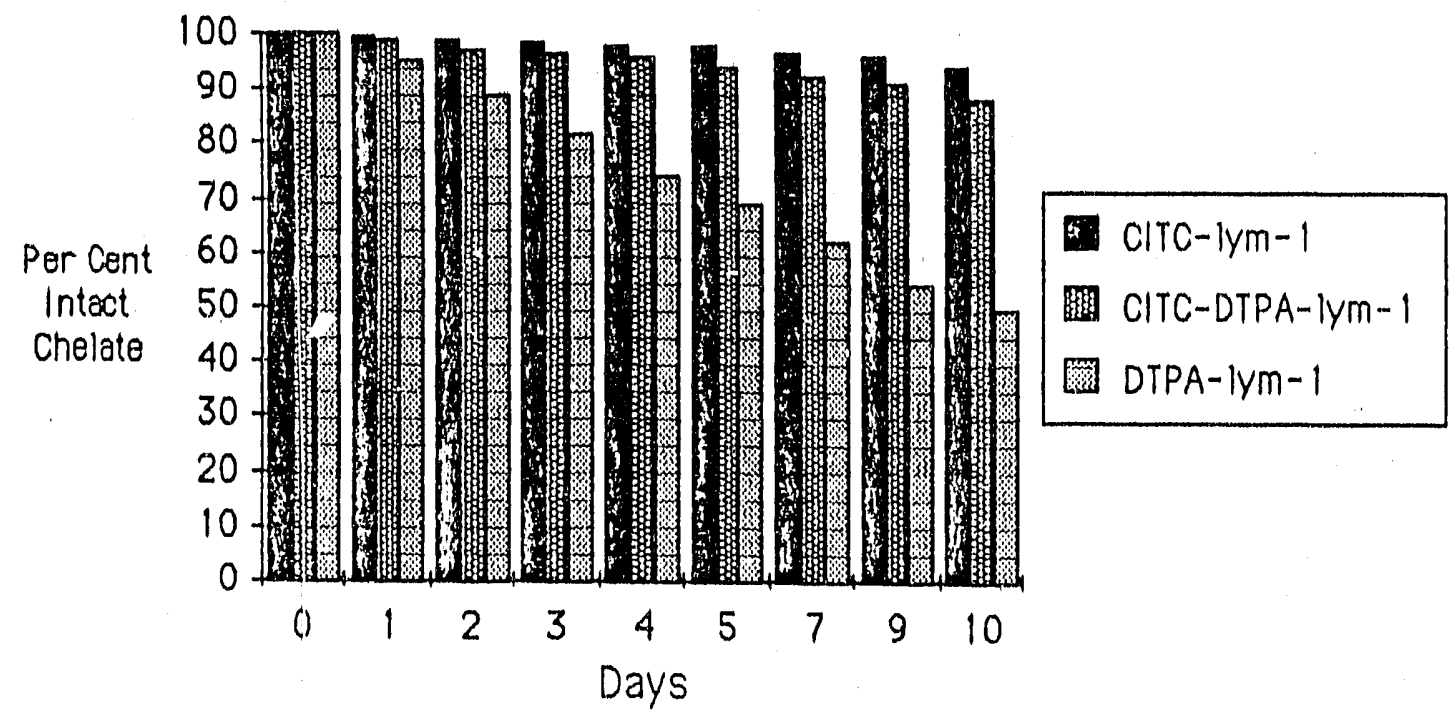

These resu ts indicate that there is very little difference between the rates of indium loss from these benzyl-EDTA and benzyl-DTPA chelates; they suggest that the benzyl-EDTA-111 In may be slightly more stable kinetically than the benzyl-DTPA-111 In, even though the latter is more stable thermodynamically. Thus bifunctional chelating agents containing benzylEDTA groups are excellently suited for use under physiological conditions, where they hold indium well enough to make it practical to investigate cleavable linkers between antibody and chelate.

Metabolism of benzy1-EDTA-111 Ir, chelates with different linkers. Since accumulation of the radionuclide in the liver decres.ses the target to non-target ratio for tumor imaging, methods to avoid this problem are being investigated. Because of our observations that benzyl-EDTA-111 In chelates remain intact from intravenous injection through urinary excretion, we have begun to explore the possibility that clearance of radioactivity from the liver can be accelerated by changing the molecular connection between antibody and chelate. The results of these studies should also apply to appropriate chelates of ${ }^{67} \mathrm{Cu}$.

We chose to compare the structures shown in Figure 3 , in which chelate and antibody are separated by a thiourea link (CITC), a thioether link (2-IT), a peptide, a diester, or a disulfide. Healthy $\mathrm{Balb} / \mathrm{c}$ mice were injected with 20 micrograms of monoclonal antibody Lym-1 (DeNardo et al., 1986), tagged with approximately 2 chelating groups per molecule, labeled with 111 In (Deshpande et al., manuscript in preparation). 


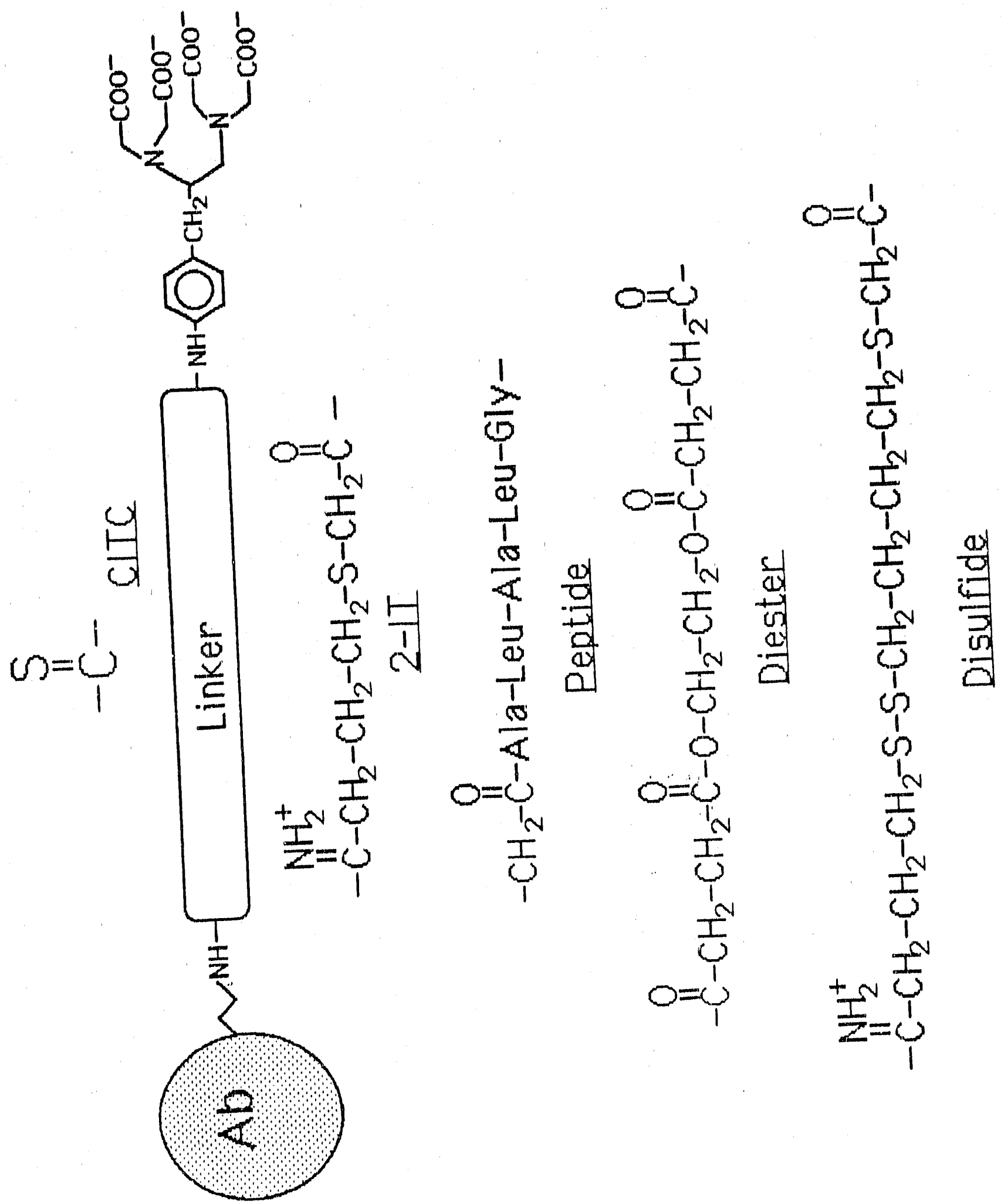

Figure 3. Linkers compared for cleavage 
Whole body. As shown in the figure below, the biological clearance of radioactivity from all the conjugates except the disulfide was similar, with a typical half-life of more than 3 days. The disulfide conjugate cleared more rapidly from the body, with a biological half-life of 12 hours. About $20 \%$ of the injected dose from the disulfide conjugate was found in the intestines in the first five hours; this contrasts with the urinary excretion characteristic of 111 In-CITC.

$$
\begin{aligned}
& \text { Whole-body Retention of In-111 } \\
& \text { Lym-1, BALB/c }
\end{aligned}
$$

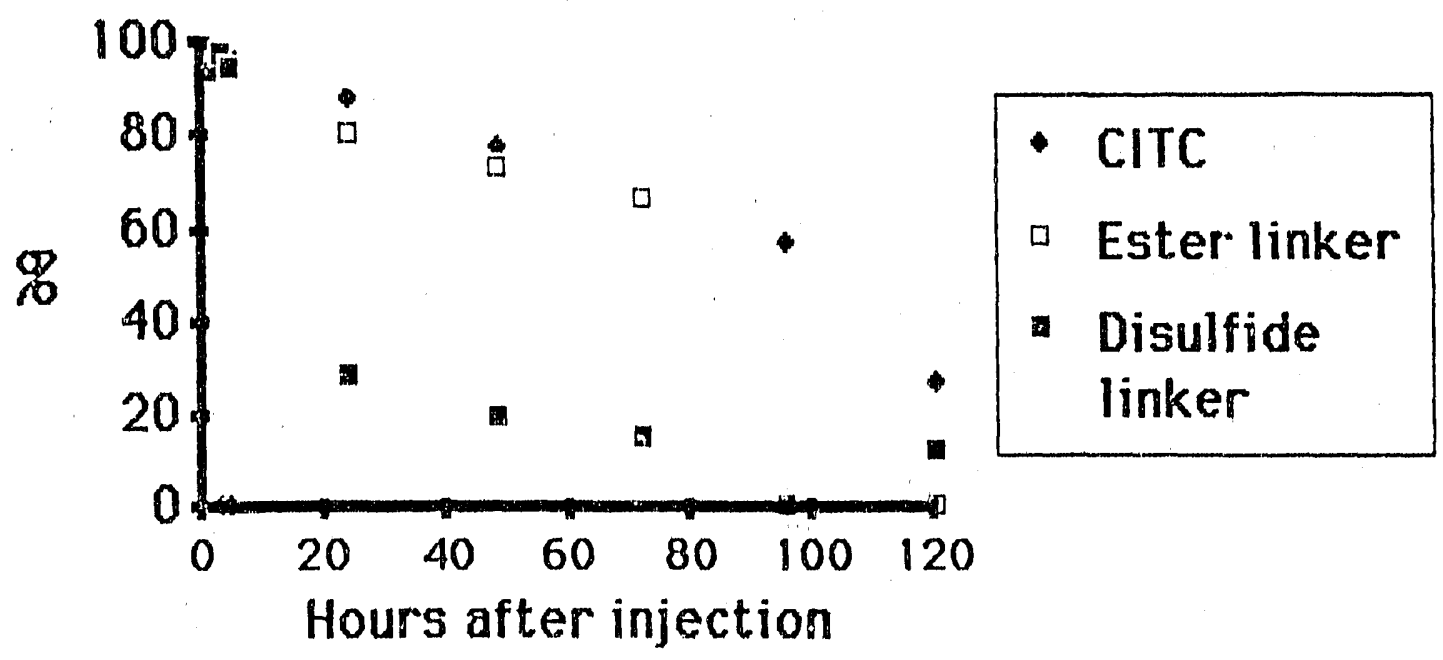


Liver. As shown in the figure below, the concentrations of radioactivity in the liver were widely different for the five linkers tested. These concentrations reflect the net result of input and output of radioactivity, and thus do not change sharply over time. The low concentrations observed with the disulfide are striking, since all the radioactivity is evidently passing through the liver to the intestines.

\section{Liver uptake of Lym-1-LINKER-benzyl- EDTA(In)}

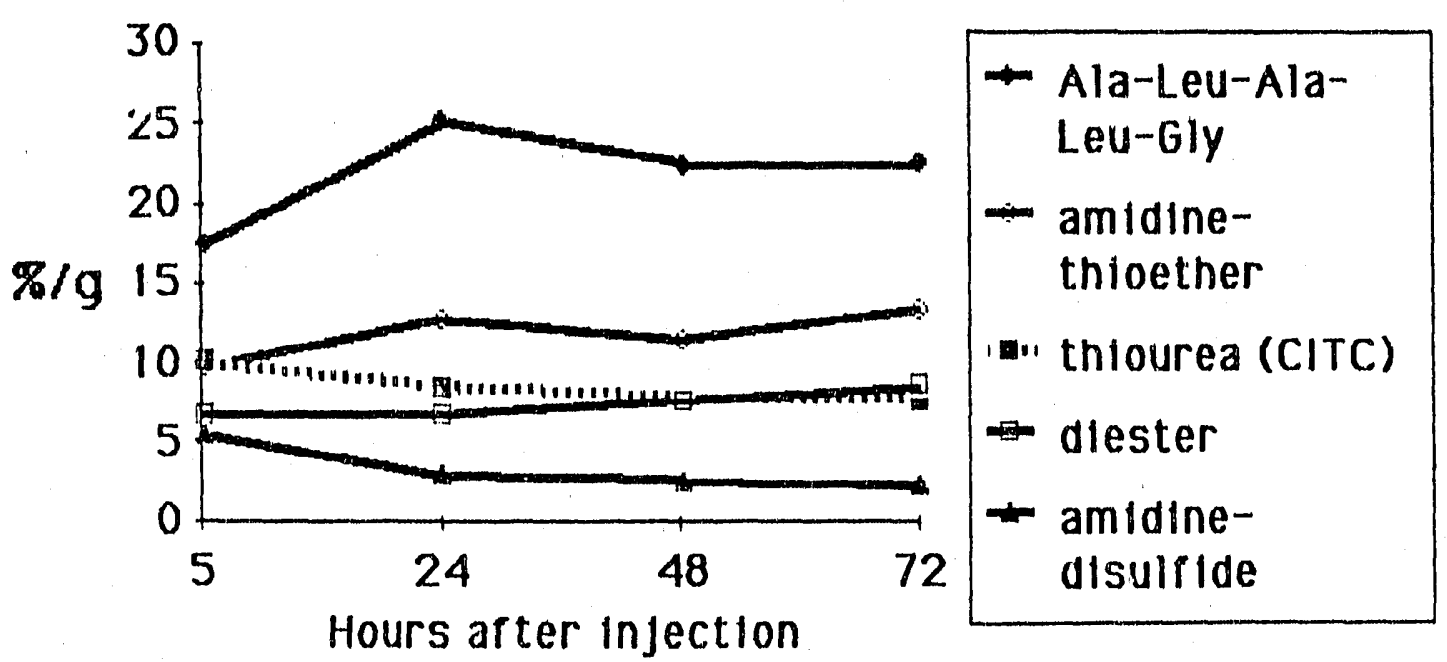

These results show that the concept of a metabolically cleavable linker to reduce liver radioactivity is sound. Further exploration is needed to produce a conjugate with the desired property of remaining intact in the circulation for long periods. 


\section{References}

Brechbiel, M.W., Gansow, O.A., Atcher, R.W., Schlom, J., Esteban, J., Simpson, D.E. and Colcher, D., Inorg. Chem., 25, 2272-2281 (1986).

Cole, W.C., DeNardo, S.J., Meares, C.F., McCall, M.J., DeNardo, G.L., Epstein, A.L., O'Brien, H.A. and Moi, M.K., Comparative serum stability of radiochelates for antibody radiopharmaceuticals, (1987), J. Nucl. Med., 28, 83-90.

DeNardo, Sally Ji; Jungerman, John A.; DeNardo, Gerald L.; Lagunas-Solar, Manuel C.; Cole, William C.; Meares, Claude F. The choice of radionuclides for radioimmunotherapy. DOE Symp. Ser., 56(Dev. Role Short-Lived Radionuclides Nucl. Med. Pract.), pp $401-14.1985$.

DeNardo, S. J., Peng, J. S., Denardo, G. L., Mills, S. L., Epstein, A. L. (1986). Im munochemical aspects of monoclonal antibodies important for radiopharmaceutical development. Nucl. Med. Biol., 13, 303.

DeNardo S.J., DeNardo G.L., Deshpande S.V., Adams G.P., Macey D.J., Mills S.L., Epstein A.L. and Meares C.F. (1987a) The design of a radiolabeled monoclonal antibody for radioimmunodiagnosis and radioimmunotherapy. In Radiolabeled monoclonal antibodies for imaging and therapy - Potential, problems and prospects.' NATO Advanced study Institute. S. Srivastava (ed.) Plenum Press, 1987.

Eckleman, W.C., Paik, C.H. and Reba, R.C. Cancer Res., 40, 3036-3042 (1980).

Hosain, F., McIntyre, P.A., Poulose, X., Stern, R.S. and Wagner, Jr., H.N., Binding of trace amounts of ionic indium-113m to plasma transferrin. (1969) Clin. Chim. Acta, 24, 69-75.

L. H. DeRiemer, C. F. Meares, D. A. Goodwin, and C. I. Diamanti, BLEDTA II: Synthesis of a New Tumor-visualizing Derivative of Co(III)-Bleomycin, J. Labelled Compounds \& Radiopharmaceuticals XVIII, 1517-1534 [1981]

Mathias, C. J. and Welch, M. J. (1987). Studies on the entrapment of Indium111 in the liver following the administration of proteins labeled using bifunctional chelates. J. Nucl. Med., 28, 657. (abstract No. 420)

Meares, C. F., DeRiemer, L. H., Leung, C. S-H., Yeh, S. M., Miura, M., Sherman, D. G., Goodwin, D. A., and Diamanti, C. I. in Adv. Chem. Ser., 198(Modif. Proteins), R. E. Feeney \& J. R. Whitaker, eds., pp. 369-87 (Amer. Chem. Soc., Washington, DC, 1982).

Meares, C.F., McCall, M.J., Reardan, D.J., Goodwin, D.A., Diamanti, C.I. and McTigue, M. Anal. Biochem., 142,68-78 1984.

Meares, C.F., Nuc. Med. Biol., 13, 311-318 (1986).

Moi, M.K., Meares, C.F., McCall. M.J., Cole, W.C. and DeNardo, S.J. Copper chelates as probes of biological systems:Stable copper complexes with a macrocyclic bifunctional chelating agent, (1985), Anal. Biochem., 148, 249-253. 
Penefsky, H.S., Metrods in Enzymol., 56, 527-530 (1979).

Reardan, D. T., Meares, C. F., Goodwin, D. A., and 6 others (1985). Antibodies against metal chelates. Nature (London), 316(6025), 265.

Ritzmann, S.E. and Daniels, J.C., Serum electrophoresis and total serum proteins, (1982), in Serum protein abnormalities: Diagnostic and clinical aspects, Ritzmann, S.E. and Daniels, J.C. (Ed.), Alan R. Liss, New York, p.3-26.

Sarkar, B., Laussac, J.-P. and Lau, S. Transport forms of copper in human serum (1983), in, 'Blological aspects of metals and metal related diseases, Ed., Sarkar, B., p.23-40, Raven Press, New York

White, A., Handler, P. and Smith, E.L., Principles of Biochemistry, (1968), 4th Edition, McGraw Hill, New York, p.711.

Yeh, S.M., Sherman, D.G.and Meares, C.F., A new route to bifunctional chelating agents: Conversion of aminoacids to analogs of ethylenedinitrilotetraceticacid. (1979) Anal. Biochem., 100, 152-159. 


\section{Research Plan, Chelate Chemistry}

\section{67Cu linked to monoclonal antibody}

From our results described in the progress report, it is clear that chelator structures related to benzyl-TETA (Figure 1) are well suited to bind copper under physiological conditions. In the coming year, we expect to complete our comparison of the three macrocycles benzyl-DOTA (12-membered ring), benzyl-TETA (14-membered ring), and benzyl-HETA (16-membered ring). Thus, early in the period of this proposal we should have made a final choice among them.

Our current results with 111 In chelates suggest that improved biodistributions may be obtained if a metabolically cleavable linker is placed between chelate and antibody. However, the optimum linker has not yet been developed. A mong the linkers in Figure 3 of the progress report, the disulfide evidently cleaves very rapidly in the liver (and possibly in the circulation also). Personal conversations with researchers on immunotoxin conjugation lead to the proposal that sterically hindered disulfide linkages may possess the requisite long circulatory lifetime, combined with rapid intracellular cleavage. Because both our macrocycle syntheses and our EDTA/DTPA syntheses involve nitrobenzyl groups for elaboration into protein-binding reactive groups, the chemistry is readily transferable. However, the syntheses are lengthy; we estimate that the efforts of a postdoctoral researcher for approximately one year will be required in order to prepare reproducibly a conjugate suitable for eventual use in humans. An example of a synthetic strategy for such a conjugate is given in Figure 4. In addition to the 2,3-dimercaptobutane depicted in Figure 4, a variety of other thiols are available.

In addition to hindered disulfides, peptides are also promising as cleavable linkages. Modern peptide chemistry provides a route to a variety of pure oligopeptides, some of which may be readily cleaved by enzymes (cathepsins) in liver endosomes. We have tried the Ala-Leu-Ala-Leu-Gly chain (Figure 3) with 111 In, but observed very high liver levels of radionuclide and slow clearance from the body. Improvements may be sought in several ways. First, a pentapeptide linker may be too short to allow access of a hydrolytic enzyme. Second, since such enzymes are usually selective for certain amino-acid sidechains, the Ala-Leu-Ala-Leu-Gly sequence might not be the best substrate. In the coming period, we will synthesize oligopeptides containing arginine, phenylalanine, and/or glutamate residues, to seek substrates for cathepsins B, C, or D (Barman, $1974)$. 

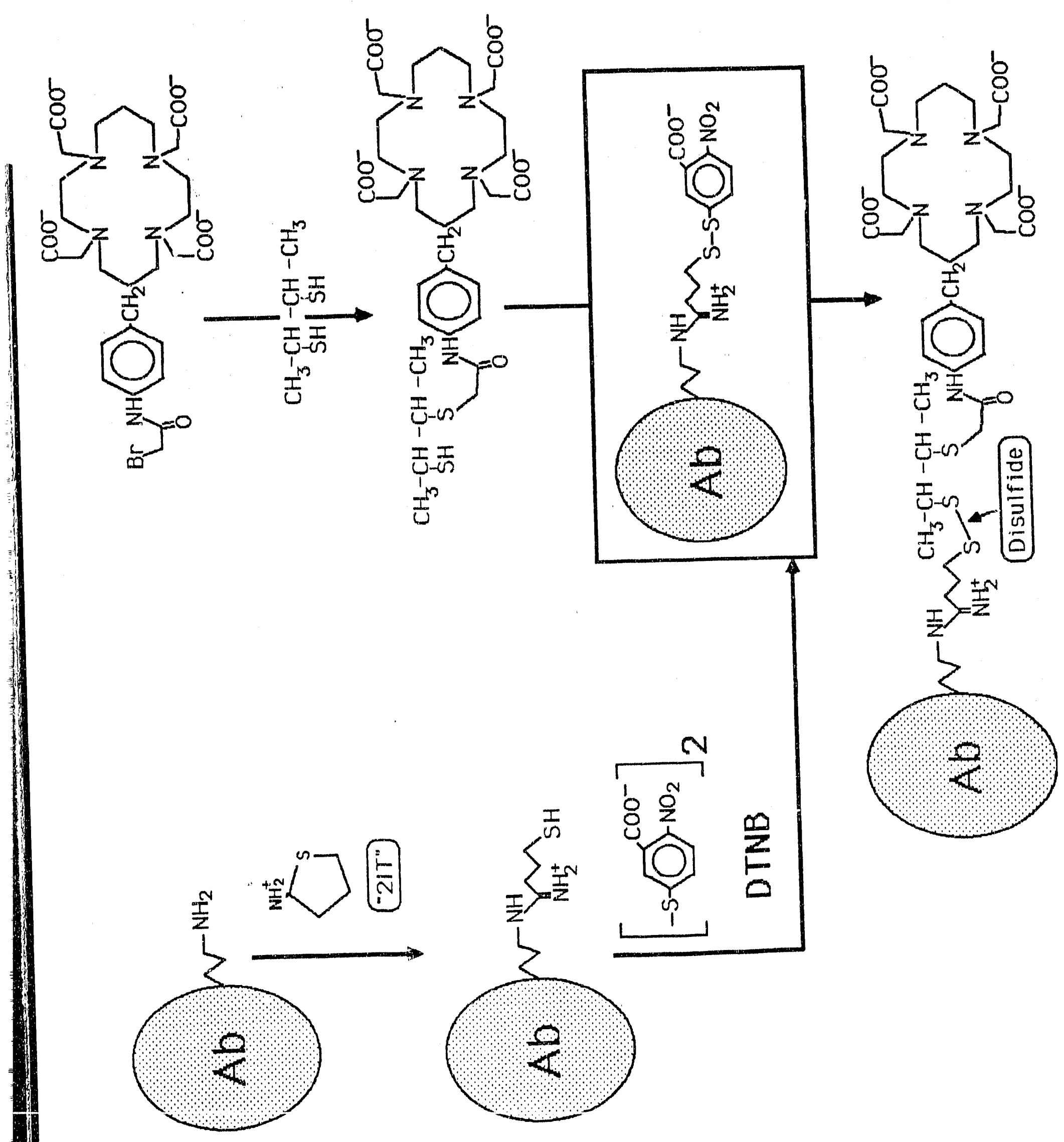

Figure 4. Macrocycle with hindered disulfide linkage. 
Oligopeptides containing 4 to 12 residues will te prepared by standard methods (Stewart \& Young, 1984). They will then be used in the synthetic strategy shown in Figure 5 to produce activated peptide-chelator conjugates for attachment to antibodies. The necessary glycylaminobenzyl-macrocycle is easily prepared from the bromoacetylaminobenzyl-macrocycle (Figure 1) by treatment with $\mathrm{NH}_{3}$. The antibody will be prepared by reaction with 2iminothiolane, as shown in Figure 1.

Because cathepsins B, C, and D are commercially available, these peptidelinked antibody-chelator conjugates will be characterized in vitrofor proteolytic lability. Simple gel-filtration separations of small molecules from macromolecules as a function of time, monitored by radioactivity, will show which linkages are most labile. Characterization of proteolysis products by TLC and reverse-phase HPLC in comparison with synthetic standards will indicate the nature of the sidegrouj remaining on the macrocycle. The linkages most promising in vitrowill be studied in viva

\section{Related macrocycles for other metals}

The dramatic difference between TETA and open-chain chelators like EDTA and DTPA with respect to holding copper under physiological conditions (Moi et al., 1984) suggests that other macrocycles might have superior properties over EDTA or DTPA for other metals. In particular, the potential of $90 \mathrm{Y}$ for use in radioim munotherapy (Order et al, 1986) indicates a need for further investigation of bifunctional chelating agents for yttrium. The kinetic inertness of the DOTA complexes of Eu(III), $\operatorname{Pr}($ III), and $\mathrm{Yb}$ (III) noted by Desreux (1980) suggests that the benzyl-macrocycles we are now preparing may have advantages for yttrium as well as copper. The work of Kimura and co-workers (1986) on macrocycles with pendant ligands is also very interesting in this regard, as it suggests a way to prepare stable macrocyclic complexes with high coordination number. We will synthesize and explore such macrocycles, both for their copper-binding and for their yttriumbinding properties. Our approach will be Michael addition of a polyamine on a nitrocoumarin or a nitrocinnamate, followed by familiar synthetic steps.

\section{Site of attachment to antibody}

With NIH support, we are studying various techniques to alter the distribution of sites on antibodies that are tagged with chelating agents. The strategy involves reversible protection and deprotection of certain reactive sidechains, and extensive peptide analysis to characterize the results. This 

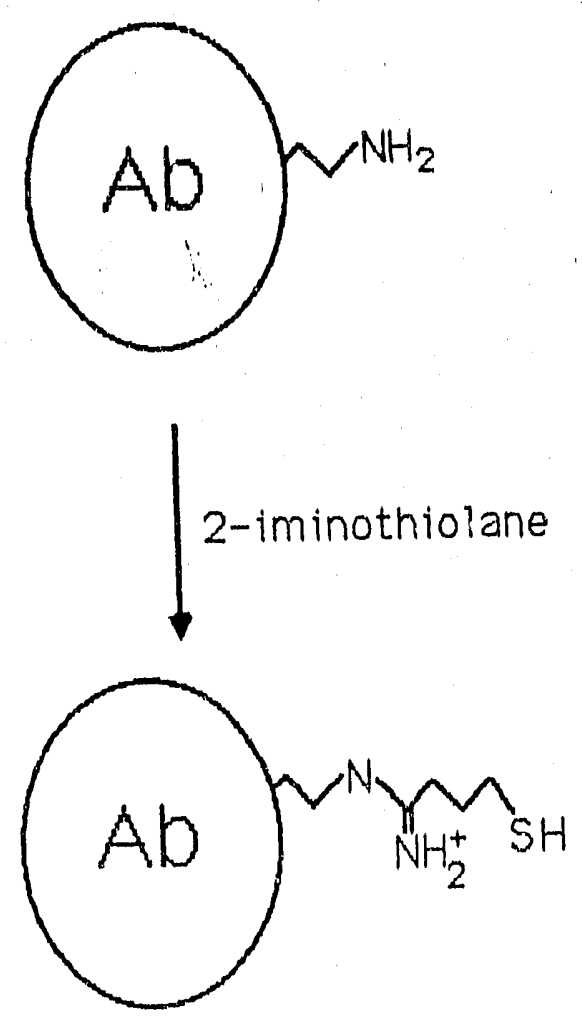
issue bears directly on the tagging of Lym-1 with ${ }^{67} \mathrm{Cu}$ and other radionuclides, and we will apply the results directly to this project, as they become available. 


\section{References, Chelate Chemistry}

Barman, T. E. (1974) Enzyme Handbook, Supplement I, Springer-Verlag, New York.

Brechbiel, M.W., Gansow, O.A., Atcher, R.W., Schlom, J., Esteban, J., Simpson, D.E. and Colcher, D., Inorg. Chem., 25, 2272-2281 (1986).

Cole, W.C., DeNardo, S.J., Meares, C.F., McCall, M.J., DeNardo, G.L., Epstein, A.L., O'Brien, H.A. and Moi, M.K., Comparative serum stability of radiochelates for antibody radiophar maceuticals, (1987). J. Nucl. Med., 28, 83-90.

DeNardo, S. J.; Jungerman, John A.; DeNardo, Gerald L.; Lagunas-Solar, Manuel C.; Cole, William C.; Meares, Claude F. The choice of radionuclides for radioimmunotherapy. DOE Symp. Ser., 56(Dev. Role Short-Lived Radionuclides Nucl. Med. Pract.), pp 401-14. 1985.

DeNardo, S. J., Peng, J. S., Denardo, G. L., Mills, S. L., Epstein, A. L. (1986). Immunochemical aspects of monoclonal antibodies important for radiopharmaceurical development. Nucl. Med. Biol., 13. 303.

DeNardo S. J., DeNardo G. L., Deshpande S. V., Adams G. P., Macey D. J., Mills S. L., Epstein A. L. and Meares C. F. (1987a) The design of a radiolabeled monoclonal antibody for radioimmunodiagnosis and radioimmunotherapy. In 'Radiolabeled monoclonal antibodies for imaging and therapy - Potential, problems and prospects.' NATO Advanced study Institute. S. Srivastava (ed.) Plenum Press, 1987.

Desreux, J. F. (1980) Inorg. Chem. 19, 1319-1324.

Eckleman, W.C., Paik, C.H. and Reba, R.C. Cancer Res., 40, 3036-3042 (1980).

Hosain, F., McIntyre, P.A., Poulose, K., Stern, R.S. and Wagner, Jr., H.N., Binding of trace amounts of ionic indium-113m to plasma transferrin, (1969) Clin. Chim. Acta, 24, 69-75.

Kimura, E. (1986) J. Coord. Chem. 15, 1-28.

L. H. DeRiemer, C. F. Meares, D. A. Goodwin, and C. I. Diamanti, BLEDTA II: Synthesis of a New Tumor-visualizing Derivative of Co(III)-Bleomycin, J. Labelled Compounds \& Radiophar maceuticals XVIII, 1517-1534 [1981]

Mathias, C. J. and Welch, M. J. (1987). Studies on the entrapment of Indium111 in the liver following the administration of proteins labeled using bifunctional chelates. J. Nucl. Med., 28, 657. (abstract No. 420)

Meares, C. F., DeRiemer, L. H., Leung, C. S-H., Yeh, S. M., Miura, M., Sherman, D. G., Goodwin, D. A., and Diamanti, C. I. in Adv. Chem. Ser., 198(Modif. Proteins), R. E. Feeney \& J. R. Whitaker, eds., pp. 369-87 (A mer. Chem. Soc., Washington, DC, 1982).

Meares, C.F., McCall, M.J., Reardan, D.J., Goodwin, D.A., Diamanti, C.I. and McTigue, M. Anal. Biochem., 142, 68-78 1984.

Meares, C.F., Nuc. Med. Biol., 13, 311-318 (1986). 
Moi, M.K., Meares, C.F., McCall. M.J., Cole, W.C. and DeNardo, S.J. Copper chelates as probes of biological systems:Stable copper complexes with a macrocyclic bifunctional chelating agent, (1985), Anal. Biochem., 148, 249-253.

Order, S. E., J. L. Klein, P. K. Leichner, J. Frincke, C. Lollo, and D. J. Carlo (1986) ${ }^{90} \mathrm{Y}$ antiferritin-a new therapeutic radiolabeled antibody. Int. J. Radiation Oncology Biol. Phys. 12, 277-281.

Penefsky, H.S., Methods in Enzymol., 56, 527-530 (1979).

Reardan, D. T., Meares, C. F., Goodwin, D. A., and 6 others (1985). Antibodies against metal chelates. Nature (London), $316(6025), 265$.

Ritzmann, S.E. and Daniels, J.C., Serum electrophoresis and total serum proteins, (1982), in Serum protein abnormalities: Diagnostic and clinical aspects, Ritzmann, S.E. and Daniels, J.C. (Ed.), Alan R. Liss, New York, p.3-26.

Sarkar, B., Laussac, J.-P. and Lau, S. Transport forms of copper in human serum (1983), in, 'Biological aspects of metals and metal related diseases, Ed., Sarkar, B., p.23-40, Raven Press, New York

Stewart, J. M., and Young, J. D. (1984) Solid Phase Peptide Synthesis, second edition, Pierce Chemical Co., Rockford, IL.

White, A., Handler, P. and Smith, E.L., Principles of Biochemistry, (1968), 4th Edition, McGraw Hill, New York, p.711.

Yeh, S.M., Sherman, D.G.and Meares, C.F., A new route to bifunctional chelating agents: Conversion of aminoacids to analogs of ethylenedinitrilotetraceticacid. (1979) Anal. Biochem., 100, 152-159. 
II. To develop therapy planning based on quantitative imaging:

Our goal has been to develop a comprehensive treatment planning system for olinioal cancer therapy with radiolabeled monoclonal antibodies against oancer-associated antigens. We expect the system to provide estimates of the radiation dose distributions assoolated with various ohoices of radionuclide and targeting moleculs.

These approaches are now feasible because of advances in quantitative radionuolide imaging. Tracer techniques can now be implemented by advanced equipment for quantitative radionuclide imaging and strengthened by dynamic modeling of the physiological parameters whioh govern radionuolide distribution, and hence radiation dose distribution (1). We belleve that the quantitative radionuolide lmaging is necessary to efficiently and accurately make decisions that can influence the efficaoy of radioimmunoimaging and radioimmunotherapy.

Preliminary clinical trials of radioimmunoimaging and radioimmunotherapy have demonstrated the feasibility as well as the complexity of these methods $(2-15)$. While monoclonal antibodies inherently possess exquisite epitoplo specificity, this does not automatically confer tissue specificity in vivo. Additional faotors interfere with tissue specificity in vivo. Beyond the opportunity for nontarget tissues to share the targeted epitope, a variety of physiological phenomena and nonspecific sources of cross-reactivity lead to accumulation of antibody in tissues other than those targeted.

As an example, the monoolonal antibody is a protein that is foriegn to the patient and may be treated differently from the patient's immunoglobulins.

We $(16-18)$ and others $(10,15)$ have reported that small amounts of antibody were cleared from the blood rapidly by receptor sites so that administration of large amounts of antibody were required in order to enhance accumulation in the tumor (12). Many decistons of this type must be made in order to implement optimal radioimmunoimaging or radioimmunotherapy $(1,19)$. 
The information required to make these deolsions of ten oannot be cbtained from observations made in speoles different from the human speoles. Some, but certainly not all, of these observations oan be made in a less objeotive manner by qualitative lmaging in patierits but large numbers of individuals are of ton required (12). We have found that the information requited for these deolstons can be obtained from rigorous, quantitative imaging studies obtained in a few individuals (Figure 1) $(1,16,18)$. The purpose of this section is to desortbe our progress with the development of quantitative imaging in pationts and to illustrate several of 1 tis potential applioations.

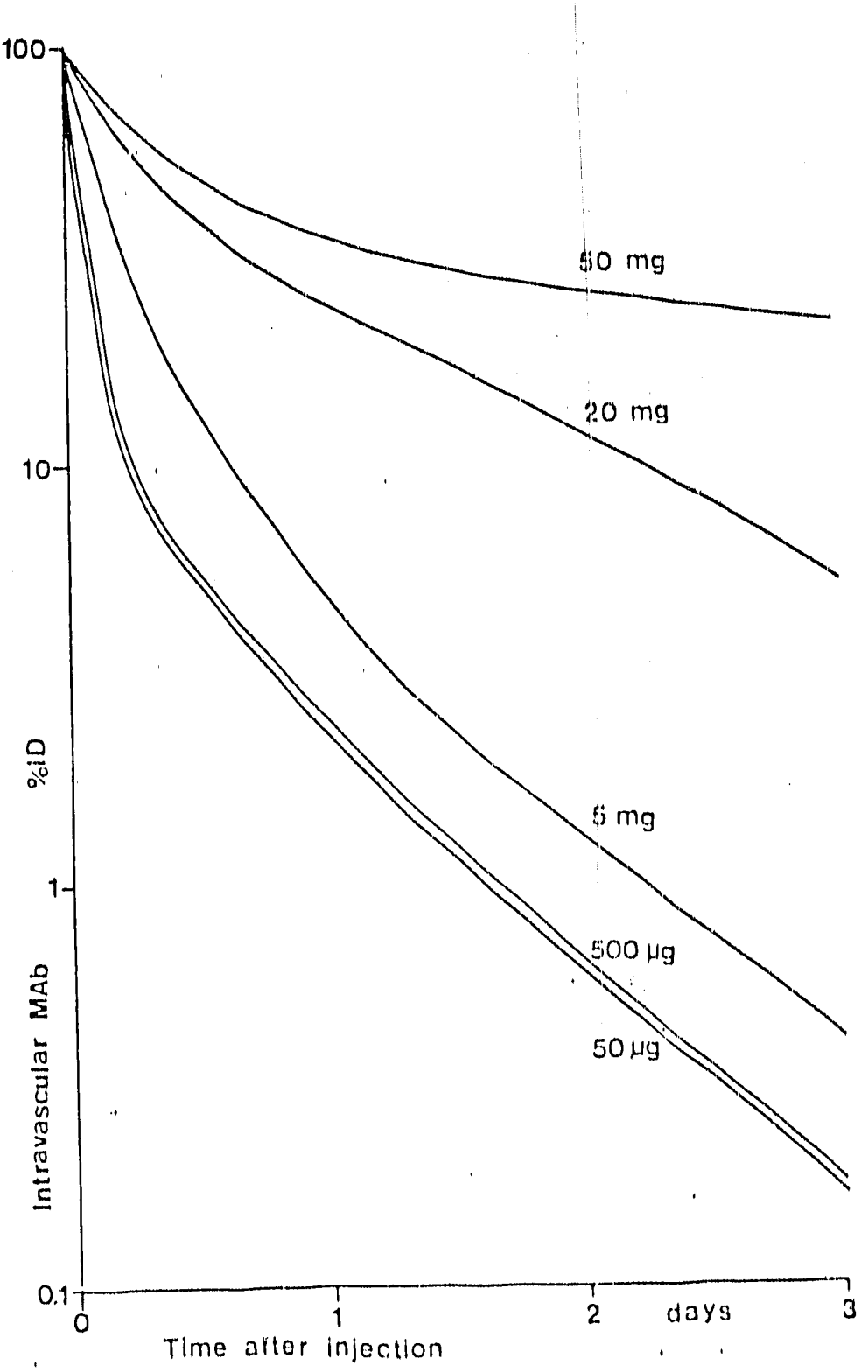

Fig. 1. Hodel simulated curves for intravascular monoclonal antibody refleot decreased blood clearance of the antibody when a larger amount of antibody is administered. Sinulated blood olearance curves for 50 and 500 ug and 5 mit were very simjlar tio those observed in patientis. 


\section{Thooretioal Baokground}

An important objective for radioimmunoimaging and radiolmmunotherapy is absolute quantitiation of the amount of radionidolide in tumors and organs of the patient so that pharmacokinetio information can be provided andogous to that provided by blodistribution studies in mloe. Radionuollde lmages deplat the distribution of labeled antibodies in vivo and are inherentiy quantitative. The amount of radionualide in a spectifo organ or site oan be estinated by relating the counts deteoted in a defined region of interest to the radionualide uptake. When all geometrical olrouingtanoes are constant, there is a linear relationship between

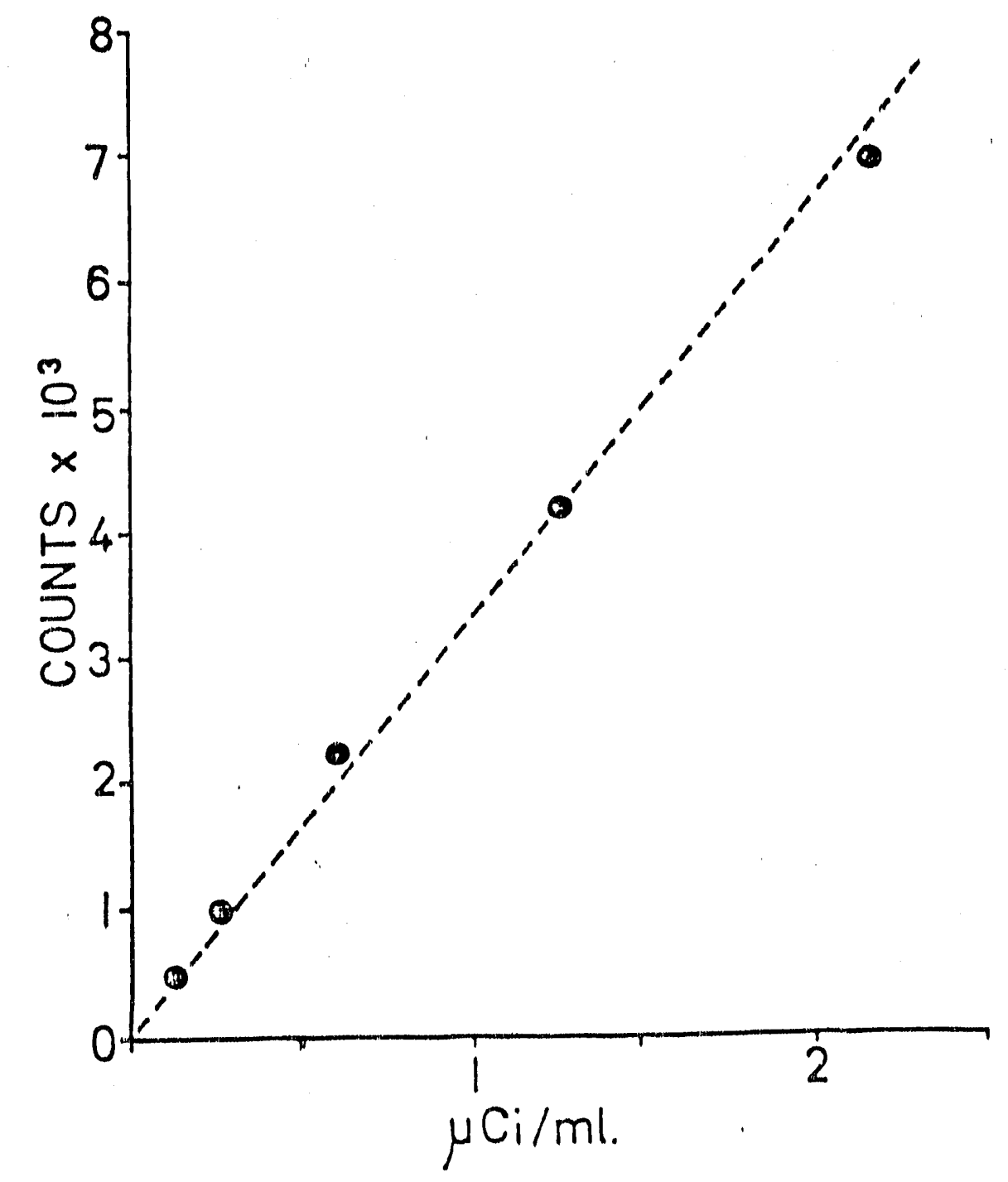

Fig. 2. A linear relationship bas observed between counts and maloactivity when a known quantity of Te-y9m was added to a constant volutile of sawdust in each simulated lung of a phantom and quantitated by SPECT at approximately six-iour intervals for 24 hours. 
the number of oounts in the regiton of interest and the amount of radioaotivity (Figure 2) so that relative change in amount of radionuclide in a tissue on be measured (F1gure 3). Measurement of total body retention of radionuolide is important for caloulating the radiation dose delivered to the body. A soanning sointillation camera intorfaced to a computer, or a simple scintillation probe, has been used by us to measure sequentially total body counts in patients who have reoeived titagnostic or therapeutio doses of radionuclide labeled agents (Figure 4). Relative measurements of the type illustrated are readily obtained. However, measurements of absolute amounts of radionuolide in vivo are more difficult (Table 1).

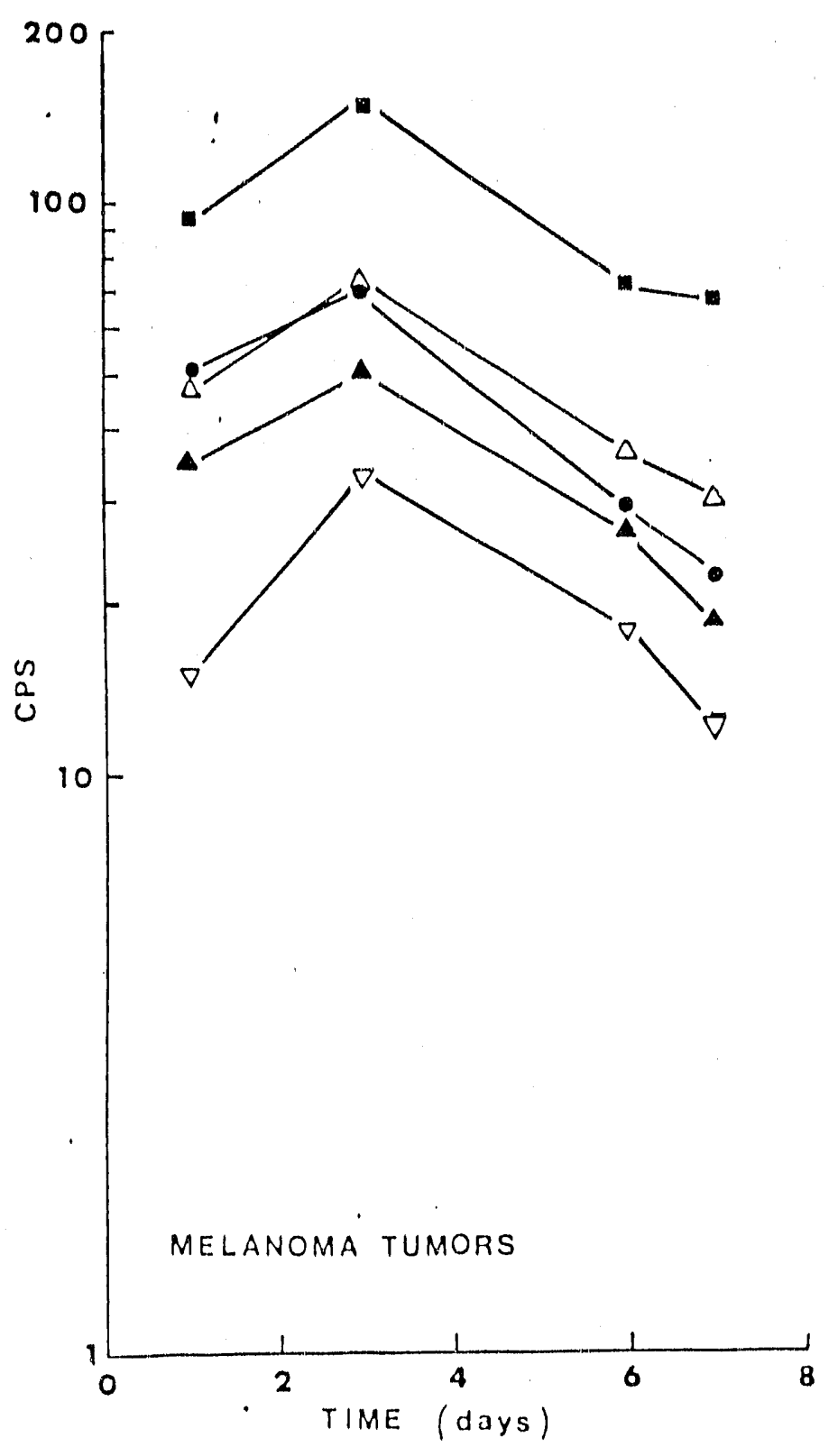

F1. 3. Decay corrected counts fron regions of interest on sequential images that defined uptake of In-111 melanoma antibody in five tumors of the pationt. Readily obtained relalive quantitations of this typo provida information on the temporal course of events. 
Tabie 1. Roquiroments for measuroment of absolute radionuolida.

1. Aoourate determination of deteotor sensitivity.

2. Definition of region of interest for organ.

3. Correotion for depth.

4. Acourate attenuation correotion.

5. Correotion for soatter and septal penetration.

6. Adequate statistios.

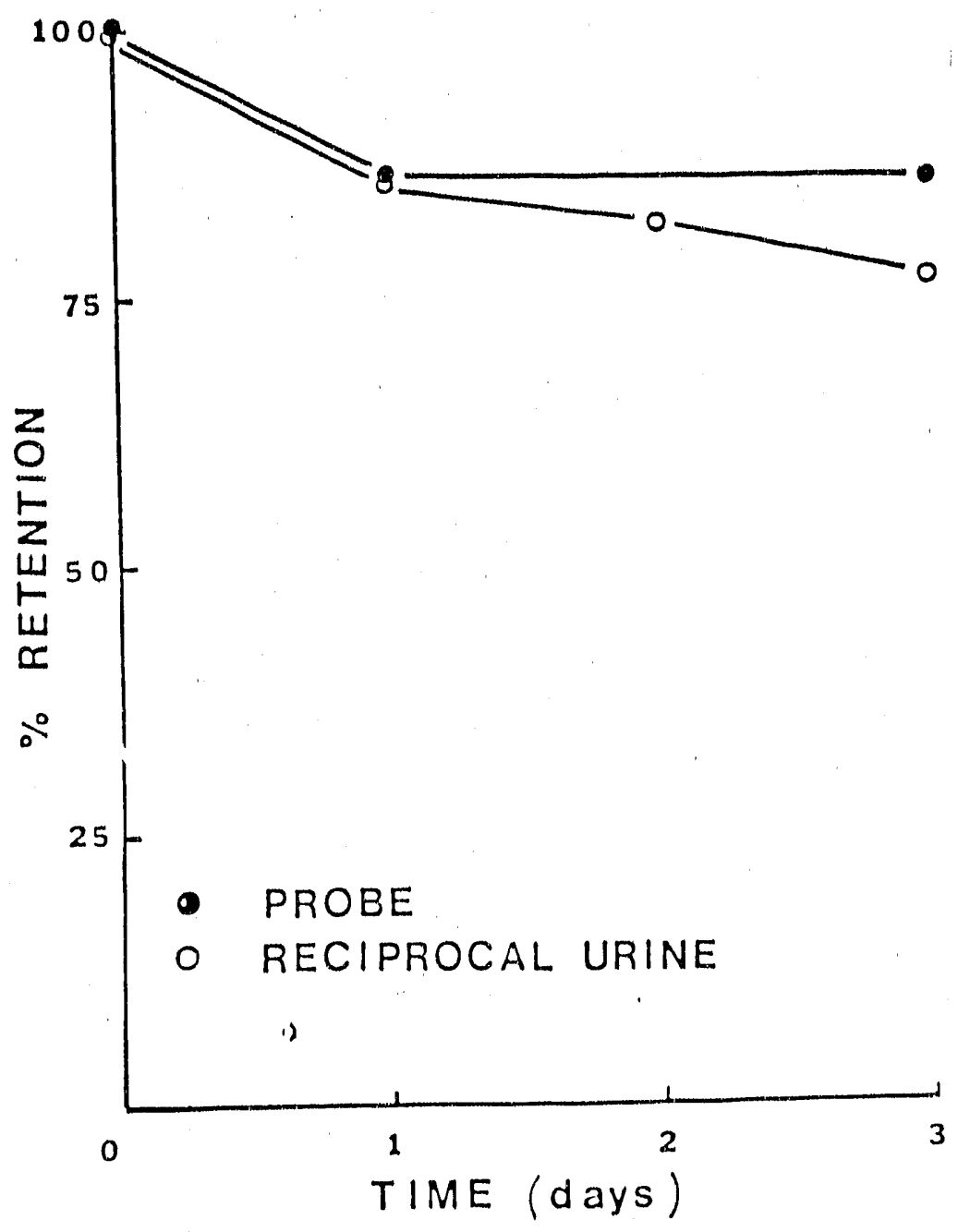

Fig. 4. Quantitation of radioactivity by placing a scintiliation probe detector two meters from the lower chest of a patient who had received $5 \mathrm{mCi}$ of In-111 melanoma antibody and was seated on a stool provided whole body retention data comparable to the reclprooal of that obtained by quantitation of radionctivity in the patient's urine with a sointillation wall detector. This antibody is not significantly excreced by routes otizer than the urine. The scintillation carnera has been used for similar purposes by the methods described in the lext and its greater effioiency permits datia to be obtained for longer intervals after administration of radionuclide. 
Images of a phantom that simulated the abdoinen of a patient and contalned radionuolide were obtialned from opposing anterior and postertor perspeotives in order to assess the acouraoy of plarar quantitative methods. Images were similarly obtained sequentialiy of patients who had reoeived radionuclide labeled agents such as antibodies, fibrinogen or 10dide. A small volume souroe of known amount of the same radionuolide was simultaneously imaged in each instanoe to serve as a standard for comparison with the amounts of radionuolide placed in the phantom or administered to the patients. Sensitivity of the sointillation oamera (Siemens Orbiter) was also determined for appropriate radionuolides on separate oocasions using small volume souroes. Prior or subsequent to emission imaging a posterior transmission image with and without the phantom or
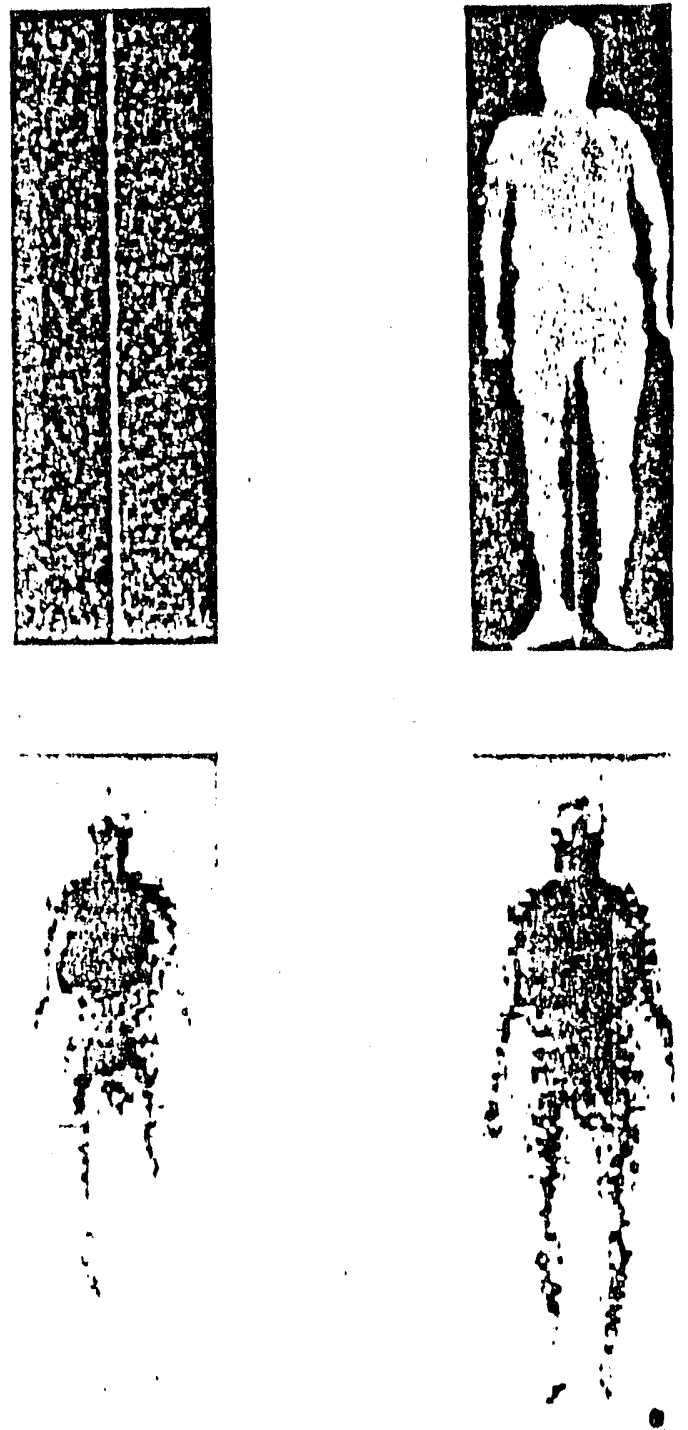

Fig. 5. Transmission images obtained with the scanning scintillation camera in the absence of and presence of the patient. Anterior and posterior emission images obtained shortly after administration of In-111 labeled antibody to this patient. In-111 standard is adjacent to fect. 
patient in situ was obtained with a $5 \mathrm{mCi}$ line source of the same radionuclide which was used to obtain the emission images in order to obtain attenuation correction factors (Figure 5).
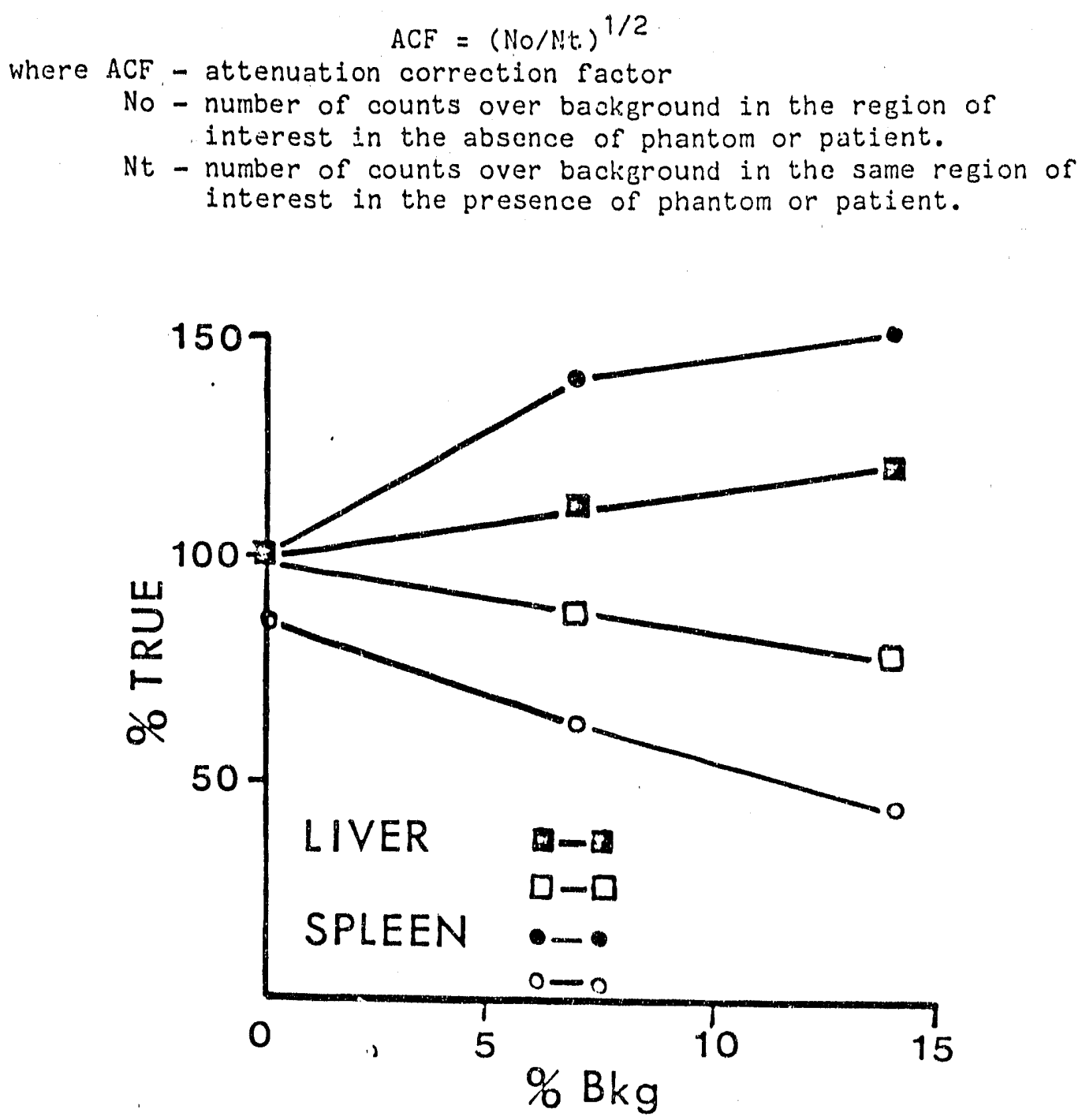

Fig. 6. Results of quantitation of $T c-99 \mathrm{~m}$ in sinulated liver and spleen of an abdominal phantom in the absence of and presence of $T c-99 \mathrm{~m}$ in the surrounding phantom using the geometric mean method and attenuation correction factors for the liver and spleen determined by transmission imaging. Quantitations were accurate in the absence of background $T c-99 \mathrm{~m}$ and background subtraction, but less accurate in the presence of background Tc-. $99 \mathrm{~m}$.

Regions of interest were manually defined on each image in order to obtain the global counts in the entire body or a selected organ or tumor in the body. Background regions on the same imace uere similarly defined in order to obtain background counts. These counts were subsequently normalized for the differing number of pixels in the target site and the background region prior to subtraction.

When the structure could be identified on only one of the opposing views, then the effective point source method of quantitation was used 
with an estimated source depth to correct for attenuation in the source and interposed tissue. Studies of the abdominal phantom indicated an effective point source for the liver $5 \mathrm{~cm}$ distant from the detector on the anterior view and for the spleen $5 \mathrm{~cm}$ distant from the detector on the posterior view.

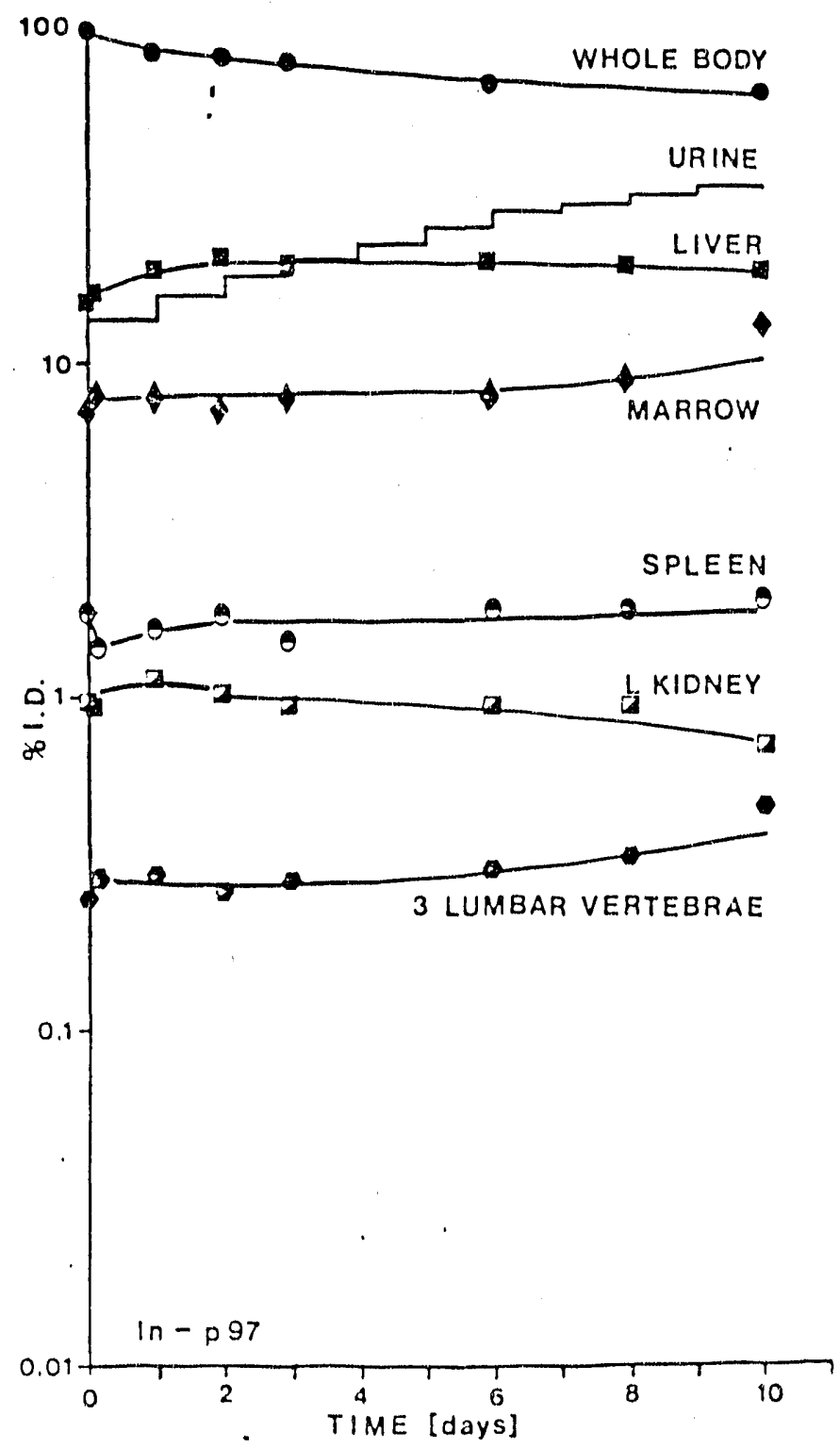

Fig. 7. Results of sequential quantitative imaging and urinary quantitations obtained from a patient who had received In-11? p-97 antibody. Harro's pharmacokinetics were calcum. lated using data obtained from three lumbar vertebrae and ilIRD formulations. :Then corrected for decay, In-111 is remarkably persistent in the tissues.

When the structure could be identified on both opposing views then the geometric mean of conjugate views method was used for quantitation. The view that best defined the structure in its maximum extent was selected to establish the appropriate region of interest, which was then 
traced on transparent film, mirror-imaged and used to define the region of interest on the opposing view.

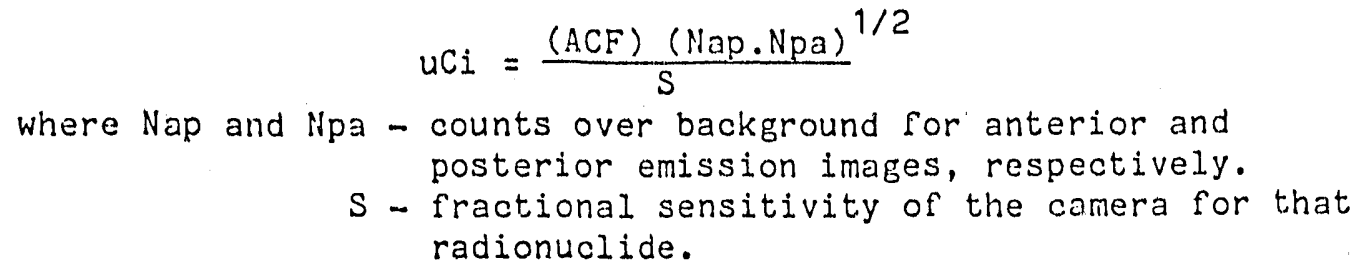
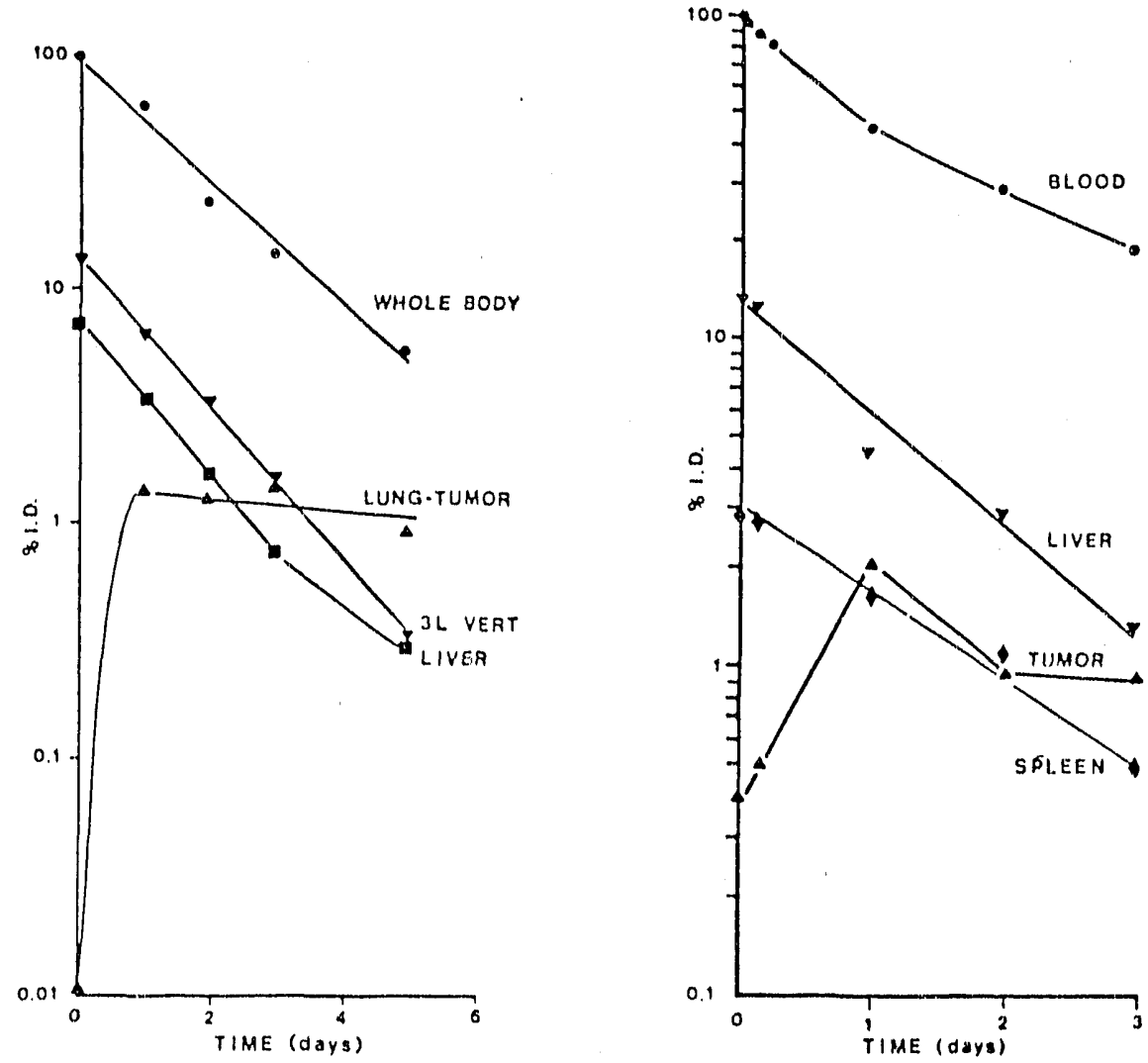

Fig. 3. Results of sequential quantitative inaging obtained from a patient who had received I-131 Lym-1 lymphoma antibody. When corrected for decay, I-131 persisted in the tumor but was rapidly cleared from the entire body and other organs. Similur kinetics were observed in a woman with a pelvic tumor who was given I-123 labeled, heavily iodinated fibrinogen (right).

\section{Studies of Abdominal Phanton}

Transmission and emission images of a phantom (Alderson phantom) which was designed to simulute the abdomen of a patient were obtained in a llanner analogious to that used cor quantitative imaging of patients in an effort to assess the accuracy of the method and influence of backsround radioactivity. The simulated liver and spleen were filled with water containing an accuratily nssayed amount of Tc-99m sufficient to provide a concentration of radioactivity comparable to that observed in patients who had received radiolabeled antibody. Water containing no radioactivity, or a concentration of radioactivity equal to $7 \%$ or $14 \%$ of that placed in the liver and spleen was put in the concavity of the trunk 
of the phantom that surrounded the liver and spleen. One million count anterior and posterior emission images were obtained and regions of interest defined by the methods described earlier.

\section{Studies in Patients}

Transmission and emission images of patients who had received intravenous antibodies labeled with In-111, I-123 or I-131, or fibrinogen labeled with I-123 were obtained and quantitations performed by the methods described earlier. The pharmacokinetics of these radiopharmaceuticals were compared. At 24 and 72 hours after injection, the amounts of $I n-111$ in the liver and body of four patients who had received In-111 p-97 antibody were compared to the amounts of $\mathrm{In}-111$ in the liver and body of four patients who had received In-111 antibody against prostate specific antigen. The first group of patients had metastatic melanoma and the second group had metastatic prostate caricer.

Melanoma specific antibody labeled with In-111 was administered to one patient and with superficial and readily measured melanomatous metastases, and quantitative imaging was performed. The amount of radionuclide in each of tre tumors and in the entire body of the patient was sequentially determined during seven days after administration of the antibody. The diametei of each tumor was measured with a caliper and the volume was calculated assuming a spheroid. The concentration of radionuclide in each tumor was calculated based upon the determinations of volume, and the concentration of radionuclide in the entire body (non-target) was calculated using the whole body quantitations and the weight of the patient. This made it possible to calculate the target to non--target relationsibip with time after injection of the antibody. Furthermore, the peak target to non-target ratio was calculated for each tumor and related to its mass assuming a density of one. The amount and concentration of radionuclide in each tumor were related to the mass of each tumor.

Three patients with lymphoma were given on separate occasions Lym-1 antibody (21) or its $F\left(A b^{\prime}\right)$, or $F(A b)$ fragments labeled with I-123. Whole antibody was administered to each patient on trio separate occasions; on one occasion the total mass of administered antibody was approximately $0.1 \mathrm{mg}$ whereas on a second occasion approximately $5 \mathrm{hg}$ was administered. The amount of radionuclide in the liver was determined by quantitative imaging on each occasion.

\section{RESULTS}

Using the techniques described, an observer became capable of obtainimg reproducible quantitative results after modest experience. Greater effort was required for two observers to obtain results comparable to each other. The major impediment to the achievement of reproducible results was related to the choice of the region for background radioactivity. There was a propensity in all instances for backiground estinates to be excessive, so that a reeion of least body background was selected.

In the absence of backsround radionuclide in the abdominal phantom and in the absence of backoround subtraction, the radionuclidic content of the liver or spleen was accurately quantitated by the described methods, including the use of a first order attenuation correction factor deterinined by uranomission imaging (Figure 6). llouever, radiomuclidio content of the liver or spleen was less accurately determined in the prosence of radionuclide in the surrounding phantom regardless of whether

$$
54
$$


general phantorn background was subtracted or not. Radionuclidic content was over-estimated when background radionuclide was not subtracted and under-estimated when background radionuclide was subtracted. The errors were greater for the spleen than for the liver and greater when larger amounts of radionuclide were placed in the abdiminal phantom.

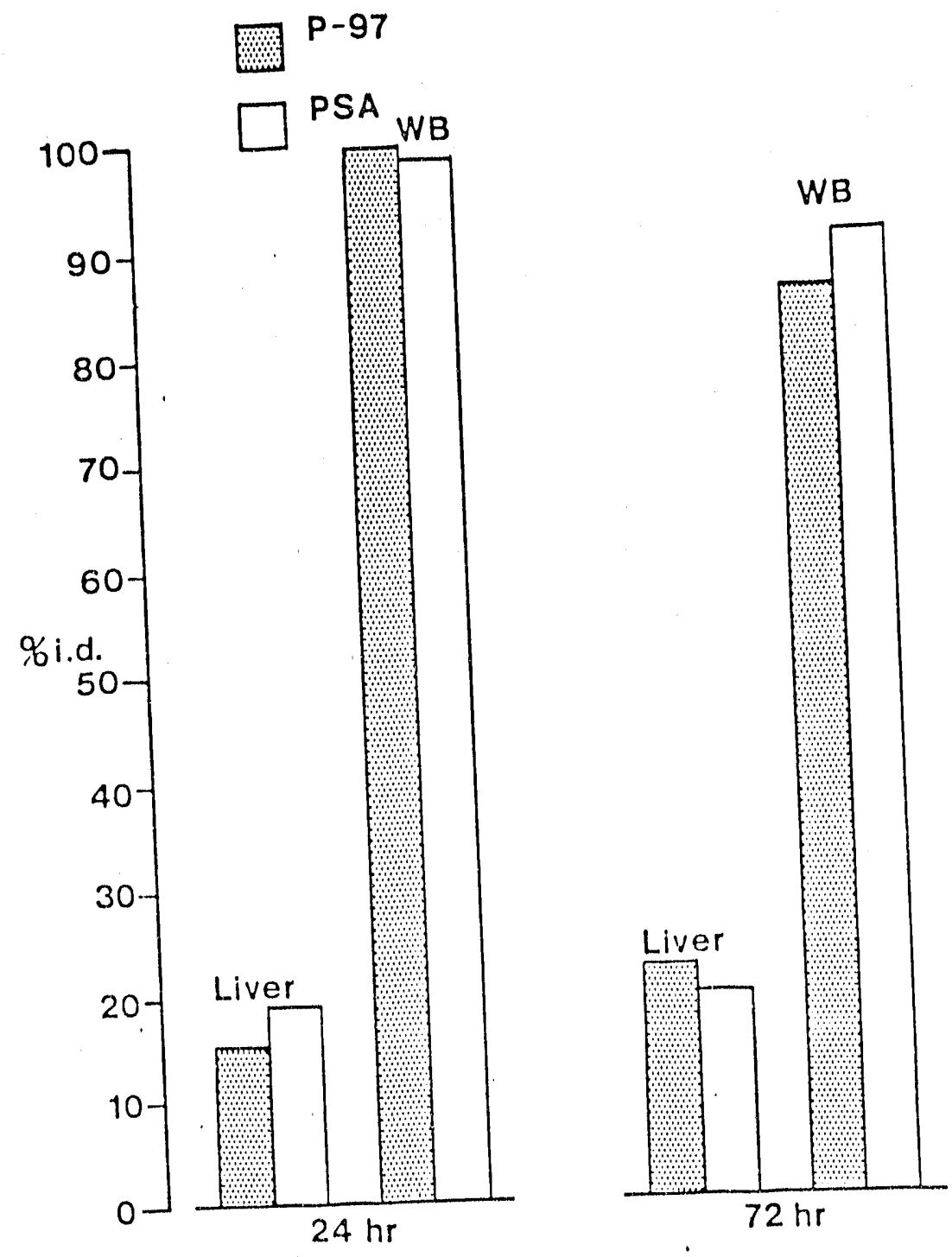

Fig. 9. Quantitative imaging in a group of patients who had received In-111 prostate specific antibody and in a second group of patients who had received $I n-111$ p-97 melanoma antibody provided data that indicaice similarities in the amounts of In111 accumulated and retained in the entire body and in the liver.

Despite these limitations, useful pharmacokinetic information was obtained from quantitative imaging of patients (Figures 7 and 3 ). Quantitative whole body imaging proved to be an offective method for measuring retention of radionuclide in the entire body. This was verified by results that showed that the amount of radionuclide determined to be in the entire body uy quaititative inasinit had a rociprocal relationship ton the amount measured in excrements (Figure 7). Furthermore, the amount of

$$
55
$$


radionuclide determined to be in the liver or spleen was remarkably similar from one patient to another for a specific radionuclide and antibody. The amount of radionuclide in the liver was also remarkably constant with time and was not different for the antibodies against melanoma or prostate speciflc antigens when the antibodies were labeled with In-111 (Figure 9).

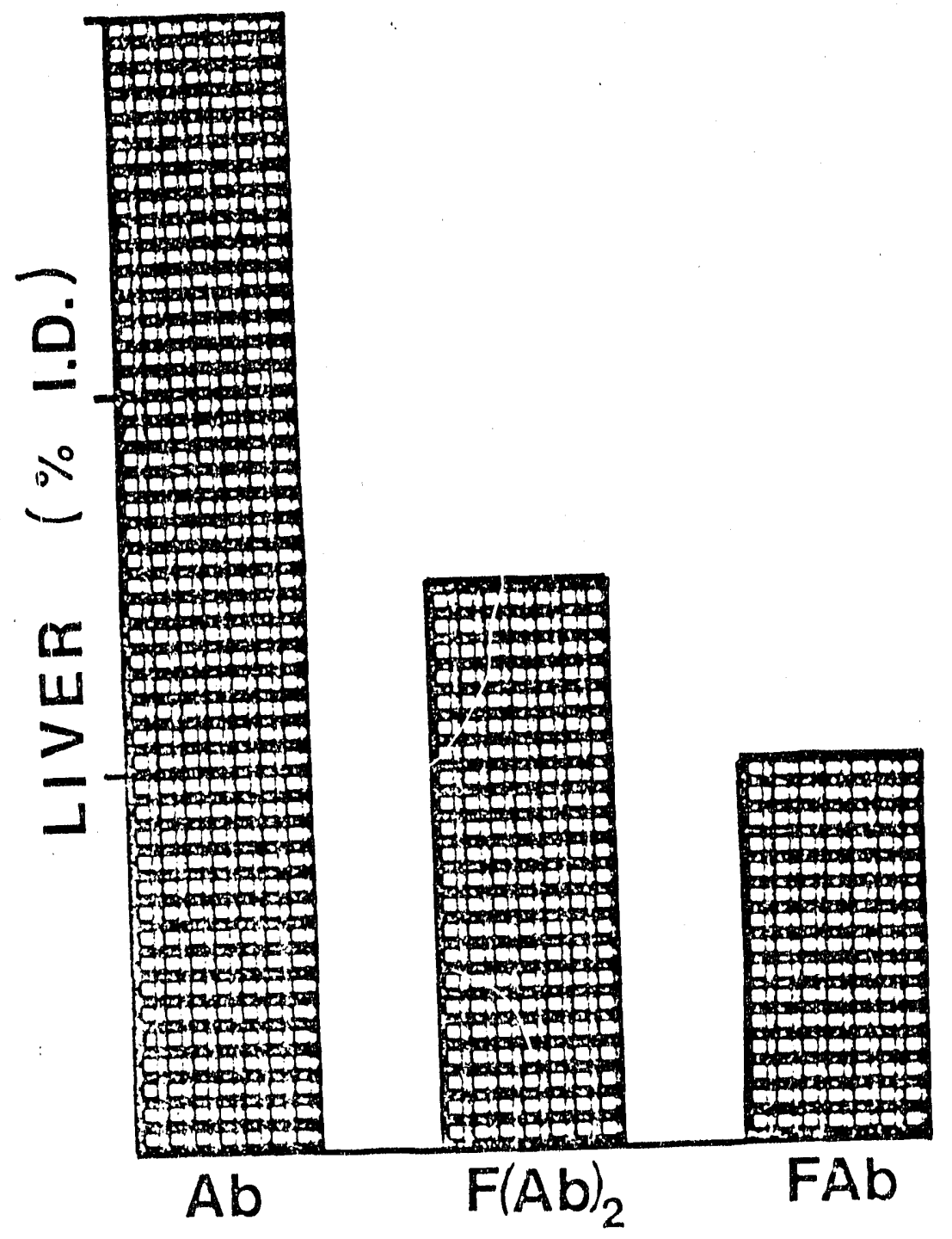

Fig. 10. Quantitative imaging of a group of patients who received $100 \mathrm{ug}$ of whole antibody $(\mathrm{Ab}), \mathrm{F}\left(\mathrm{Ab} \mathrm{b}^{\prime}\right)$, or $F(A b)$ fragments on separate occusions revealed that. the amount of the $I-123$ label in the liver was dependent upon the molecular species. When $4-5 \mathrm{mg}$ of whole antibody was administered, the amount of $I-123$ in the liver was comparable to that observed when $F\left(A b^{\prime}\right)$ was administered.

Less radionuclide was found in the livers of patients who had received I.-123 or I-131 Lym.-1 antibody and radioiodine was nore rapidly eliminated from the liver and body of these patients (Fiture 3 ). This was not necessarily the case for tumors in these patients. The amount of radionuclide in the livers of patients who had received Lym-1 ivas influenced by the amount of whole antibody they had received and by the size

$$
56
$$


and nature of the nolecular species (Figure 10). Shortly after administration, smaller amounts of radionuclide were found in the liver. when fragments of Lym-1 were administered and when a larger mass of Lym-1 whole antibody was administered.
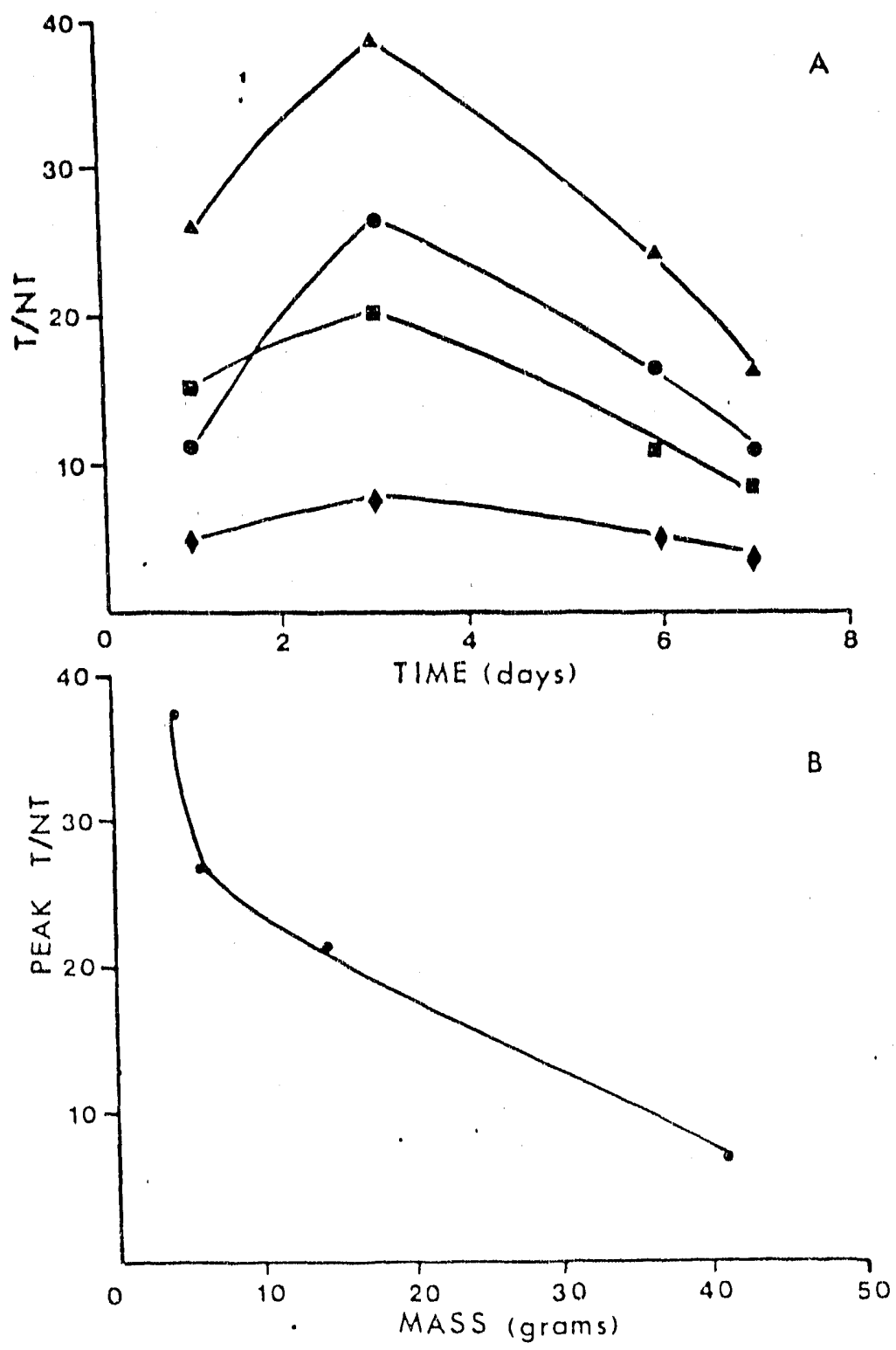

Fig. 11. Results obtained by sequential quantitative imaging of four netastatic tumors in a pa-tient who had received In-111 melanoma an-tibody were used to calculate tumor to non-target (whole body) ratios. A) Tumor to non-target ratios for the tuinors were greatest three days after injection of antibody, suggesting that this might be the optimal time for imaging. B) Tumor to non-target ratios at chree days decroased as the masses of the tunors increased.

In the pationt with matastitic melanoma who had received In-111 lam beled anti-nelanona antibody, the target to non-target ratio of all four tumors was maximun three days after administration of radiopharmaceutical and declined thereafter (Figure 11A). The poak target to non-target ra- 
tio was greatest for the smaliest tumor and progressively decreased with increasing size of the tumors (Figure 11B). The total amount of radionuclide in the tumors increased with logarithmic increase in the masses of the tumors and the concentration of radionuclide in the tumors decreased with logarithmio increase in the masses of the tumors (Figure 12).
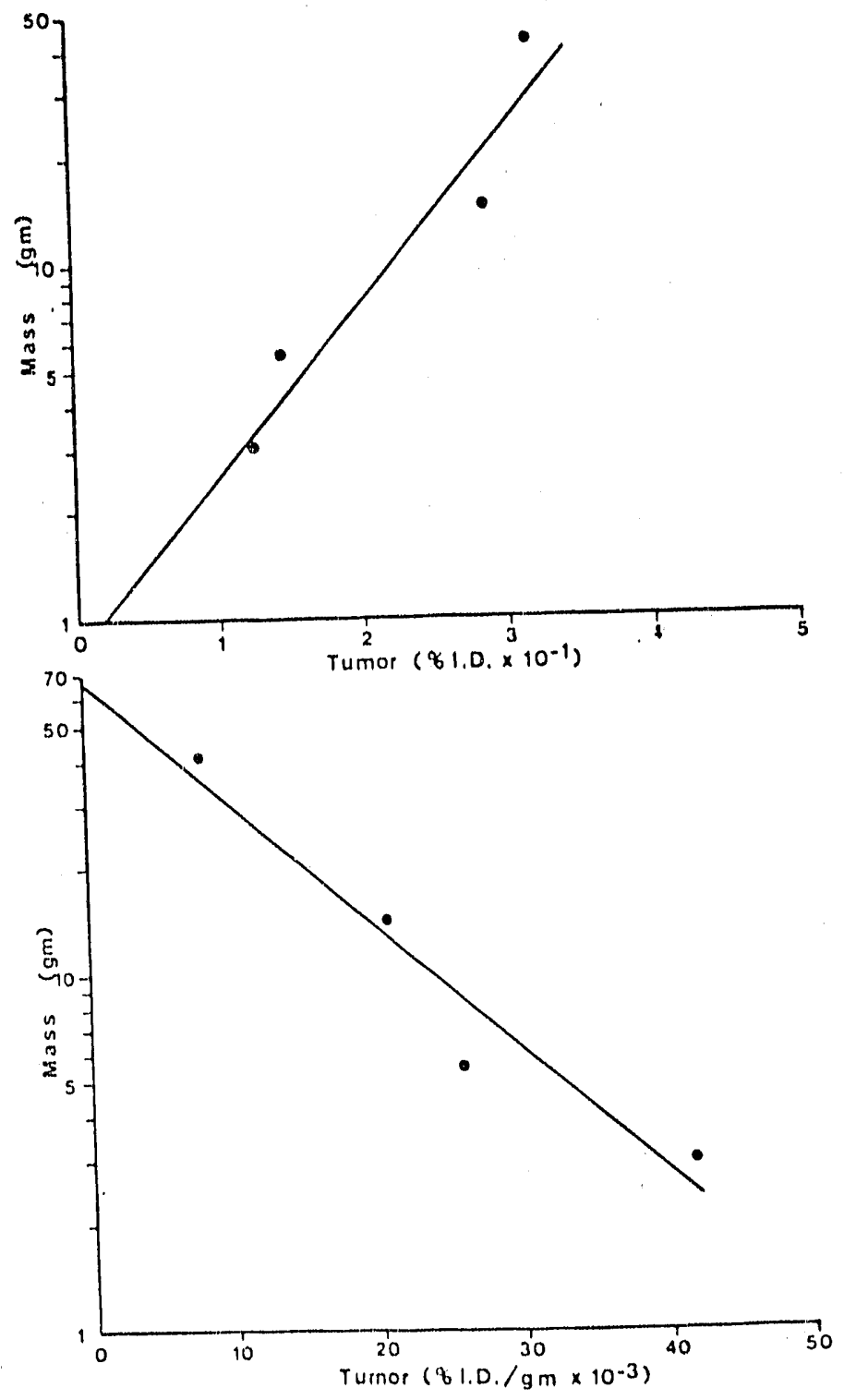

Fig. 12. Calculations from the data for the same four tumors discussed in Figure 11 revealed that the amount of In-111 increased linearly and that the concentration of the In-111 decreased linearly in these tunors with logarithmic increase in the masses of the tumors.

QUANTITATIVE IMAGING AND THERAPY PLANNING: WORK PIANNED

For radiopharmaceuticals administered to patients, quantitative radionuclide imaging can provide definitive pharmacokinetic information of a type analogous to that obtained by biodistribution studies in other species. As illustrated, this pharmacokinetic information can be used to 
obtain definitive and relevant answers to basio questions of importance for optimizing radiolmmunolmaging and radiolmmunotherapy, and in addition, oan provide a data base upon whioh to oaloulate the distribution of radiation absorbed doses. However, there are signifioant obstaoles to aoourate quantitative 1 maging in patients. Quantitation by planar imaging is relatively simple but has several serious problems, which when present, are relatively insoluble. The geometrio mean of counts detectedin opposing views of a source in the body corrects for the depth of the souroe and transmission imaging can be used to provide a first order attenuation correction faotor for the thiokness of the body. Self-attenuation of photons in the souroe can be neglected for organs up to $10 \mathrm{om}$. thick thereby permitting absolute quantitation of radionuolide to be estimated to better than $10 \%$ (22). Unfortunately, the geometrio mean method of ten cannot be used because of inability to observe the organ on a seoond view or superimposition of a second organ on the first organ on at least one of the views. This necessitates the use of the method of effective point source assumption when at least one view oan be obtained with superimposition of organs. A more serious and less soluble problem relates to the requirement to subtract background. General room background fails to refleot soatter into the organ from surrounding radionuclude in the body or other organs. When body background is small relative to the amount of radionuolide in the organ to be quantitated, then background is an insignificant problem and oan be ignored.

Unfortunately, this is often not the case with radiolabeled biologic agents despite their supposed specificity. The problem is further complicated by the question of whether one wishes to determine specific uptake of radionuclide in the organ, that is, radionuclide content above the intravascular and interstitial fluid oontent, or total radionuclide. Subtraction of body background represents an effort to obtain quantitation of the specific component.

Single photon emission computed tomography represents a powerful technological advance to quantitative clinical radionuclide imaging. It eliminates most of the cross-contamination from one source to another in imaging the body, thereby reducing the problem of background. However, we have found that septal penetration can continue to be a significant source of scatter from surrounding radionucluide into the organ of interest for some radionuclides and some collimators (23).

Emission tomography also effectively eliminates the problem of superimposition of radionuolide-containing organs. In addition to sharing some of the problems of quantitative planar imaging, quantitative tomography must address other difficulties such as the requirement for accurate boundary determination in each transverse section and greater sensitivity to errors in the at tenuation correction. (We $(1,20,22,23)$ and others $(24-32)$ have made some progress in addressing these requirements. 
The principal obstaole in the use of SPECT for absolute quantitation has been the inolusion of a large fraotion of the counts that arise from soatter, typloaliy $30 \%$ of the oounts deteoted in a regton of interest that outiline the boundary of an organ on a transverse seotion Image provided by SPECT. The soattered events that orliginate from the souroe aotivity are added to soatter from all other souroes that are Inside and outside any partioular transverse seotion both inslde and outslde the direot fleld of view of the oamera. A number of methods have been investigated to subtraot this soatter fraction from the transverse seotion image or the projection images. These inolude a dual energy soatter subtraotion approaoh(33) and a deconvolution approach (34). While these methods have been validated for quantitation of souroes in phantoms they will be diffioult to apply in olinioal praotice beoause of the complexities of intersiloe soatter, partlaularly if some of the souroes in the body are outside the direot fleld of view. Also both soatter subtraction methods add a signiflaant proportion of nolse to an Iready noisy SPECT 1 mage. We have investigated an improved method of attenuation correotion using a post-reconstruotion matrix that also yields transverse seotion images in which the soatter fraction is subtracted.

Past and present work: Our primary objeotive has been to develop SPECT quantitation so that the radionuolide content in a total organ such as the liver or spleen oan be determined after administration of a radiolabeled monoclonal antibody to a patient. We have developed a calibration phantom method that can be used for SPECT quantitation invivo. The phantom consists of 4 souroes in a oresoent shaped former that is placed under the patient lying on the SPECT couch and soanned simultaneously with the patient. The 4 sources are aocurately measured solutions of the radionuclide administered to tho patient (Figure 1). The sensitivity for each transverse seotion is provided from the number of counts per UCl in each of the oalibration solutions. Figure 1 illustrates 16 conseoutive transverse section images of the oalibration phantom solutions and the liver and spleen filied with Tc99-m. The sensitivity provided by the calibration phantom solutions is used to derive the UCi conterit in any other organ or uptake area of the same atterluation corrected section image.

We have found that the calibration phantom method can be used to determine the radionuclide content of a liver and spleen of an abdominal phantom to an accuraoy of abut 10\%(35)(Table 1). When the transverse section images were oorrected for attenuation using the post reconstruction correction matrix(36) Generated with the narrow beam LAC value of $0.15 / \mathrm{cm}$ for the 140 key photons emitted by $T \mathrm{c}-99 \mathrm{~m}$ all the oalibration phantom sources and the liver and spleen were similarly elevated by the same scatter fraction, so that quantitiation was still possible (Flgure 2). When a modified soatter compensation post-processing correction matrix was used the number of counts recorded was found to be soatter free and the radionuclide content of the liver and spleen was determined to be better than 10\% (37).

We have also investigated improved methods of bundary definition for attenuation correction in SPEC'T (38) Three compton scatter methods were investigated using a source of $\mathrm{Tc}-99 \mathrm{~m}$ and we propose to use a dual window soatter method to deftne the boundary of individual 


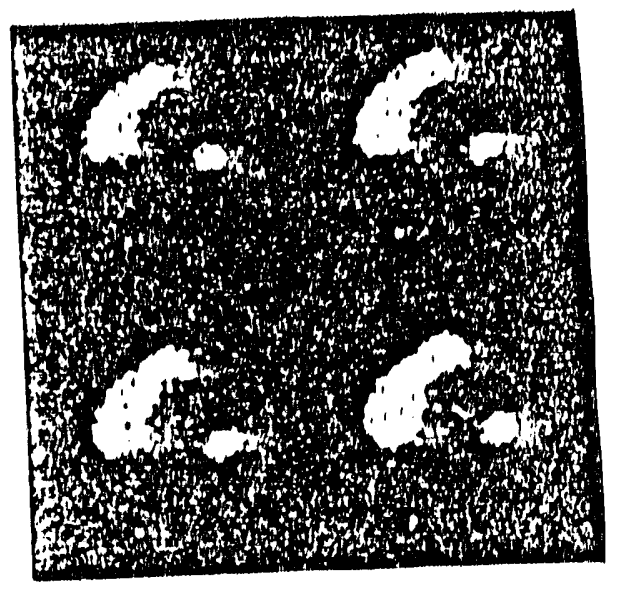

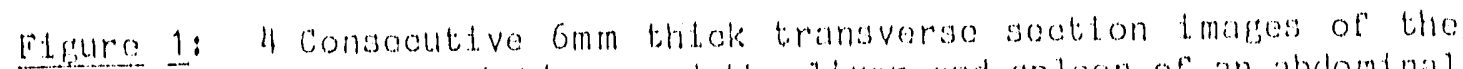
adibration phantom solutions and the liver and aploon of an abdominal. phantom. The transverse seotion tinases wore correoted for atianuaton

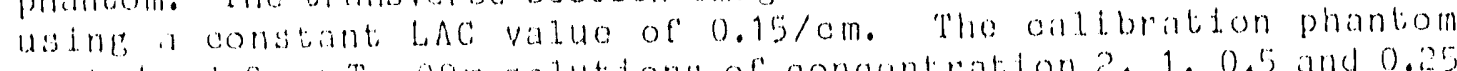

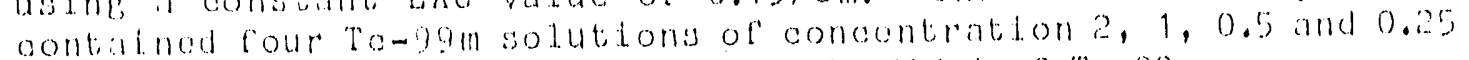

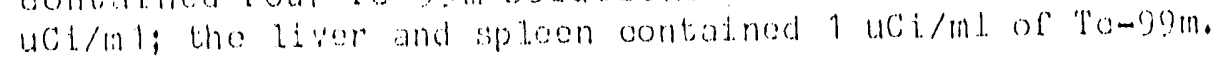

$\lambda$

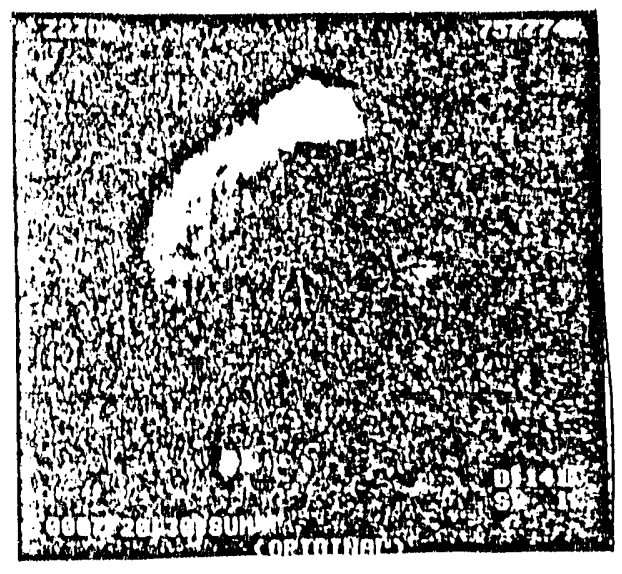

C

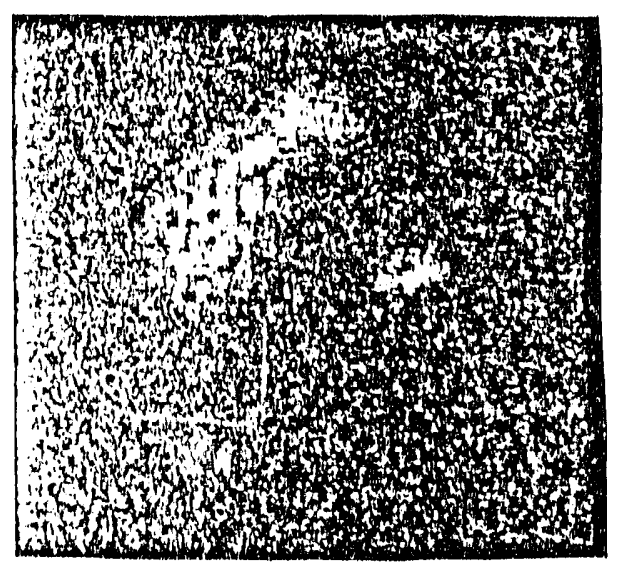

1)

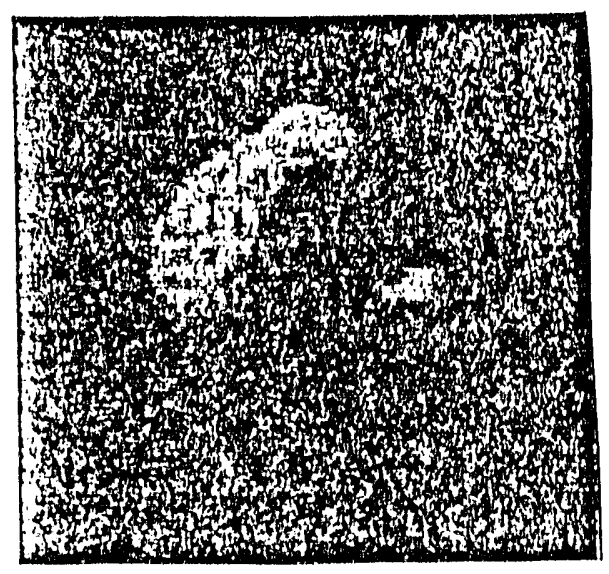

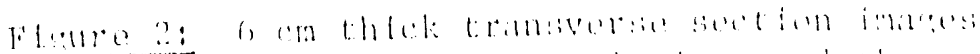

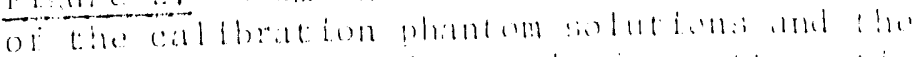

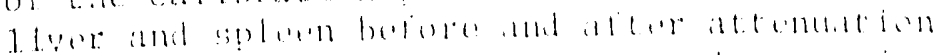

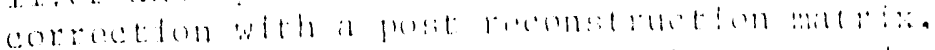

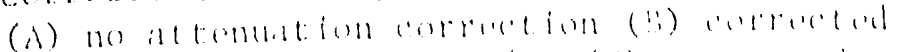

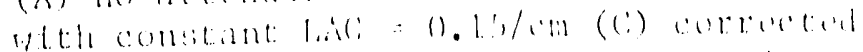

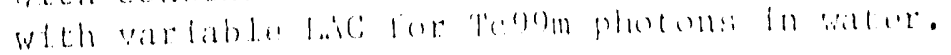


Table 1: Estimated radiomuclide content of liver and spleen in abouminal phantom derived from the semsitivity measumed fmom the calibration solutions. The sengitivity measured for a source scanned in air is also given for compartson.

\begin{tabular}{|c|c|c|c|c|c|c|}
\hline Qrgan & $\begin{array}{l}\% \text { trme } \\
\text { no corr }\end{array}$ & $\begin{array}{c}\text { radi onluelide } \\
\text { CONMU }\end{array}$ & $\begin{array}{l}\text { Eontent } \\
\text { VAFIMU }\end{array}$ & $\begin{array}{r}\text { Ser } \\
\text { ConithLs }\end{array}$ & $\begin{array}{l}\text { EIVITYY } \\
\text { VAFIMU }\end{array}$ & $\begin{array}{l}E / L C L 1 \\
\text { atr }\end{array}$ \\
\hline 11 ver & $\Xi \pi . \theta$ & 109 & 106 & 969 & $\theta 1$. & 818 \\
\hline spleen & $2 \theta .7$ & 103 & 99.3 & 969 & Q1I & $81 \theta$ \\
\hline
\end{tabular}


transverse sections for attenuation correotion in patient studies.

Future Researoh: We plan to implement the oalibration phantom method for routine olinioal studies. The oalibration phantom method overoomes the effeots of ohanging aoquisition and image prooessing parameters suoh as reconstruotion algorithm, flltering, smoothing and interslioe averaging. Clinioal implementation of the method depends on obtalning acourate soundary information from patients. We have aoquired the hardware and are setting up the software for a dual energy window SPECT computer system and expeot to 1 mplement this SPECT quantitive procedure to measure the uptake of radiolabeled antibodies in cancer patients.

Absolute quantitation of radionuclide uptake in patient studies will be validated in phantoms for other radionuolides such as I-131 and $\mathrm{Cu}-$ 67 .

For regional quantitation of radionuolide uptake we propose to implement the deconvolution method proposed by Axelsson (33). This method correots the transverse seotion image by deconvolving the influence of soatter, absorption and oollimator spread response in air. The influenoe of soatter and collimator spread will be deconvolved in the projeotion lmages before filtered baokprojection and attenuation correction oan then be applied for a narrow beam LAC value. The point spread function for a radionuclide source at various distanoes in air and varlous depths in water will be used to characterize the camera response and these will be used in the deconvolution process. The influence of soatter from sources in the same section and adjacent sections needs to be evaluated.

Finally, emission tomography is $11 \mathrm{mited}$ by 1 ts resolution and by statistics. However, we continue to believe that acourate quantitation of radiolabeled antibodies in patients requires emission tomographic imaging methods and recent developments make implementation of these methods more realistic. Pharmacokinetic information obtained in patients by these methods can provide answers to questions of basic 1 mportance to radioimmunoimaging and radioimmunotherapy. This pharmacokinetic information also provides the basis for calculating the distribution of radiation absorbed doses in order to put radioimmunotherapy on a sound scientific basis. The following types of questions will be answered by the use of this information (Table 2).

Table 2. Issues to be resolved using pharmacokinetio information:

1. Whether or not to treat the patient?

2. How to treat the patient?

a. Which radionuclide?

b. Ihich molecular species (antibody, fragment, ete) to use?

c. How much antibody to administer?

d. How much radionuclide to administer?

e. Can the patient be re-treated?

3. Evaluation of results of treatment by comparison with the distribution of radiation absorbed doses. 
REFERENCES

1. G. L. DeNardo, A. Raventos, H. H. Hines, P. O. Sohelbe, D. J. Maoey, M. T. Hayes and S. J. DeNardo. Requirements for a treatment planning system for radiolmmunotherapy. Internat1. J. Rad. Ono. B101. Phys. 11:335-345 (1985).

2. J. A. Carrasquilio, H. A. Krohn, P. Beaumier, R. W. MoGuffin, J. Brown, K. E. Helistrom, I. Helistrom, S. M. Larson. Diagnosis of and therapy for solid tumors with radiolabeled antibodies and Immune f'ragments. Cancer Ireat. Repts. $68: 317-318$ (1984).

3. J. F. Chatal, J. C. Saccavini, P. Fumoleau, J. Y. Doulilard, C. Curtet, M. Kremer, B. Le Mevel, H. Koprowski. Immunosointigraphy of colon oaroinoma. J. Nuc. Med. 25:307-314 (1984).

4. F. H. DeLand, D. M. Goldenberg. In vivo oanoer diagnosis by radiolmmunodeteotion. In: Radiolmmunolmaging and Radiolmmunotherapy. 3. W. Burohiel and B. A. Rhodes, eds, Elsevier Solence Publishing Co. (1983).

5. G. L. DeNardo, S. J. DeNardo, D, J. Macey. Cancer treatment with radioactive labeled antibodies. In: Nuolear Medioine in Clinical Oncology, C. Winkler, ed., Springer-Verlag, Berlin, Heldelberg (1986).

6. A. A. Epenetos, Clintcal results with regional antibody-guided irradiation. Cancer Drug Delivery 2:233 (1985).

7. A. A. Epentos, S. Mather, M. Granowska, C. C. Nimmon, L. R. Hawkins, K. E. Britton, J. Shepherd, J. TaylorPapadiminitriou, H. Durbin, J. S. Malpas, W. F. Bodmer. Targeting of lodine-123 labeled tumor assooiated monoclonal antibodies to ovarian, breast and gastrointestinal tumors, Lanoet 2:999-1004 (1932).

8. A. L. Epstein, A. M. Zimmer, S. M. Spies, S. Milis, G. DeNardo, S. DeNardo. Radiolmmunodetection of human B cell lymphomas with a radiolabeled tumor-specific monoclonal antibody (Lym-1). In: Malignant Lymphomas and Hodgkin's disease: Experimental and Therapeutio Advances, F. Cavali1, G. Bonadonna, M. Rozeneweig, eds., Martinus Nijhoff Publishing, Boston (1985). 
9. D.il. Goldenberg, F. DeLand, E. Kim, S. Bennett, F.J. Prinus, J.R. van Nagell, N. Estes, P. DeSimone, P. Rayburn, Use of radiolabeled antibodies to carcinoembryonic antigen for the detection and localization of diverso cancers by external photoscanning, New Eng. J. Med. 298:1384-1388 (19'78).

10, S.E. Halpern, R.O. Dillman, K.F. Hitztum, J.F. Shega, P.L. Hagan, W.M. Burrows, J.B. Dillman, M.L. Clutter, R.E. Sobol, J.M. Frincke, R.M. Bartholomew, G.S. David, D.J. Carlo, Radioimmunodetection of melanoma utilizing In-11196.5 monoclonal antibody: A preliminary report, Radiology 155:493-499 (1985).

11. J-P. Mach, J-F. Chatal, J-D. Lumbroso, F. Buchegger, M. Forni, J. Ritschard, C. Berche, J-Y. Douillard, S. Carrel: Tumor localization in patients by radiolabcled antibodies against colon carcinoma, Cancer Res. 43:5593-5600 (1983).

12. J.L. Murray, M.G. Rosenblum, R.E. Sobol, R.M. Bartholomew, C.E. Plager, T.P. Haynie, H.F. Jahns, J.H. Glenn, L. Lamki, R.S. Benjamin, N. Papadoupoulos, A.W. Boddie, J.M Frincko, G.S. David, D.J. Carlo, E.M. Hersh, Radioimmunoimaging in malignant melanoma with In-labeled monoclonal antibody 96.5 , Cancer Res. 45:23762331 (1935).

13. L.F. O'Grady, G.L. Deilardo, S.J. Dellardo, Radiolabeled monoclonal antibodics for the detection of cancer. Am. J. Physiologic Imaging 1:44-53 (1936).

14. S.E. Order, Monoclonal antibodies: Potential role in radiation therapy and oncology, Internat. J. Rad. Onc. Biol. Phys. 3:1193-1201 (1932).

15. H.G. Rosenblun, J.L. Murray, T.P. Haynie, H.J. Glenn, M.F. Jahns, R.S. Benjamin, J.M. Frinclie, D.J. Carlo, E.l" Hersh, Pharmacokinetics of $111-$ In labeled anti-P97 monoclonal antibody in patients with metastatic malignant melanora, Cancer Res. 45:2332-2386 (1935).

16. G.L. Deilardo, S.J. Deivardo, J-S. Peng, L.F. O'Grady, S.L. Mills, A.L. Epstoin, R.D. Cardiff, Evidence of a saturable hepatic receptor for mouse r:onoclonal antibodies, J. llue. Hed. 26:67 (1935).

17. S.J. Deilardo, G.L. Dellardo, L.F. O'Grady, J-S. Peng, D.J. Hacey, S.L. Mills, R.D. Cardiff, A.L. Epstein, Uuman Kinetic distribution of I-123 intact antibody, J. Muc. Hed. 26:112 (1985).

18. K. Coizumi, G.L. Deilardo, S.J. Deilardo, d...3. Peng, D.J. Hacey, K. Hisada, $N$. Tonami, Wulticompartmental analysis of the linetics of monoclonal antibody in cancer paticnts, J. iluc. iled. $27: 1243 \cdots 1254,(1936)$.

19. S.J. Dellardo, G.L. Dellardo, J-S. Pend, D. Colcher, Honoclonal ancicody radiopharmaceuticals for cancer radioimunotherapy, in: Radioinmunoimaging and Radioimmunotherapy, S. Burchiel, B. Rhodes, eds., Elsevier Publishing, Hew York (1333).

20. D.J. Hacey, R. Marshall, The lungs, in: Computed Emission Tomograpiny, P.J. El1 and B.L. Llolman, eds., Oxford Universily Press, ivew Yoris, Toronto, pp. 495--520, 1982

21. A.L. Epstein, R.J. Harder, J.H. Winter, E. Stathoponlos, F-Y. Chen, d.ii. Parker, C.R. Tayior, Tiso new monoclonal antibodies, Lym-1 and Lym-2, reacrive with human 3 lymocytes and derived tumors aitin immunodiagnostic and immunotherapeutic potential, Cancar Res. In press.

22. D.J. Aacey, R. Marsinall, Absolute quantitation of radiotracer uptake in tho lunjs dsing a gamma canera, J. illic. ind. 23:731.-73't (1982).

23. D.J. Macey, G.L. Dullardo, S.J. Deilardo, H.H. llines, Comparison of low- and medium-energy collinators for SPECT imaging with rodine123 labeled antibodies. J. lluc. Hed. 27:1467-14747 (1936). 
24. F.B. Atkins, R.N. Beck, P.B. Hoffer, D. Palmer, Dependence of optimum baseline setting on scatter fraction and detector response function in medical radionuclide imaging, IAEA, Vienna (1977).

25. J.W. Beck, R.J. Jaszczak, R.E. Coleman, C.F. Starmer, L.H. Nolte, Analysis of SPECT including scatter and attenuation using sophisticated lonte Carlo modeling methods, IEEE Irans. Nuc. Sci. 506511 (1932).

20. T.F. Budinger, S.E. Derenzo, W.L. Greenberg, G.T. Gullberg, R.H. Huesman, Quantitative potentials of dynamic emission computed tomography, J. Nuc. Med. 19:309-315 (1978).

27. T.F. Budinger, G.T. Gullberg, Transverse section reconstruction of gamma-ray emitting radionuclides in patients, in: Reconstruction Tomography in Diagnostic Radiology and Nuclear Medicine, M.M Ter-Pogossian, M.E. Phelps, G.L. Brownell, et al, eds., University Park Pres, Baltimore (1977).

23. R.J. Jaszczak, L.T. Chang, U.A. Stein, F.E. Moore, Whole body single-photon emission computed tomography using dual, largefield-of-view scintillation cameras. Phys. Med. Biol. 24:11231143 (1979).

29. R.J. Jaszczak, R.E. Coleman, F.R. Whitehead, Physical factors affecting quantjtative measurements using camera based SPECT, IEEE Trans. iluc. Sci. 28:69--80 (1981).

$30 \mathrm{~J} . \mathrm{W}$. Keyes, Perspectives on tomography, J. Nuc. Med. 23:633-640 (1982).

31. G. Muehliehner, J.G. Colsher, E.W. Stoub, Correction for field nonuniformity in scintillation camera through removal of spatial distortion, J. Wuc. Hed. 21:771-776 (1980).

32. M.E. Phelps, Emission computed tomotraphy. Seminars in Muc. Hed. $7: 337-365,1977$.

33. R. J. Jaszczak, K. L. Greer, C. E. Floyd, C. C. Harris, R. E. Coleman. (1984) Improved SPECT quantification using compensation for scattered photons. J. Nuc. Med. 25. 893-900.

34. B. Axelsson, P. Maki, A. Israelson (1934). Subtraction of comptonscattered photons in single photon emission computerized tomography. J. Nuc. Med. 25. 490-494.

35. D. J. Macey, G. L. DeNardo, S. J. DeNardo. (1984) A calibration phantom for absolute quantitation ö́ radionuclide uptake by SPECT. J. Nuc. Med. 25.p.105.

36. I. T. Chang. (1978) A method for attenuation correction in radionuclide computed tomography system. IEEE Trans. Nuc. Sci. NS-25(2), 638-643.

37. D. J. Macey, G. L. DeNardo, S. J. DeNardo, A. J. Seibert. (1.086) A modified post processing correction matrix for SPECT. SPIE vo1. 671, 189-192. Physics and engineering of computerized multidimensional imaging and piocessing.

38. D: J. Macey, G. L. DeNardo, S. J. DeNardo. Comparison of three boundary detection methods for SPECT. J. Nuc. Med. (in press). 
3.0 TO DEVELOP METHODS TO ENHANCE DELIVERY OF THE RADIOPHARMACEUTICAL MOAb TO THAT TUMOR.

We have initiated work in this area in murine studies with Lym I, acquiring baseline tumor/injected dose effects. Sequential in vivo NT-360 NMR Spectral measurements of phosphate metabolites in the tumors with $\mathrm{P}-31$ surface coil nuclear magnetic resonance were obtained for twenty tumors at intervals of several days for six weeks in order to establish the characteristic metabolic pattern with growth. Studies were initiated at tumor volumes of approximately 50$100 \mathrm{~mm}^{3}$ and continued until the tumors were several grams in size. Metabolite patterns were constant until the tumors reached approximately $600 \mathrm{~mm}^{3}$ when there was subsequent progressive decrease in phosphocreatine followed by decreased ATP and relative ATP to $P i$ suggesting anaaerobic metabolism.

The normal growth pattern of this human lymphoma tumor was established and the influence of external beam irradiation on growth was determined (refer to attached figure). 250 cGy (rads) altered tumor growth and 1,500 cGy (rads) nearly completely prevented tumor growth up to one month after the acute dose was administered. These data provided a basis for comparison with the effects of radioiodinated LYM-1 therapy on tumor growth. Sixty mice were divided into a control group, a group who received approximately $520 \mathrm{UCi}$, $450 \mathrm{uCi}$ or $225 \mathrm{uCi}$ of I-131 Lym-1 intravenously. Tumor volume and mouse weight were followed up to 120 days. I-131 Lym-1 treated mice had a course substantially different from the control mice (refer to attached figure). Tumor volumes of treated mice became less and this was most profound for the highest dose of radioactivity; ten tumors treated with I-131 Lym-1 completely disappeared and did not return. Tumor volumes of the control mice increased until two months after escape from the immunosupressive effects of the preimplant total body irradiation used to permit even the nude mice to allow growth of human lymphoma. Nine additional. tumors developed in the control mice whereas only one developed in the I-131 Lym-1 treated mice. The maximum tolerated dose of I-131 Lym-1 when superimposed upon the external beam irradiation appears to be approximately 520 uCi. These observations provide the basis for subsequent pursuit of sequential NMR patterns. They also indicate the exciting and unanticipated opportunity not only to follow the metabolic pattern of regression following radiolabeled antibody treatment, but also that which appears to occur quite late in the control tumors, thereby allowing us to make additional observations in an effort to develop predictive metabolic patterns.

These results confirm that immunospecific monoclonal antibody can be used to target and treat eflectively human lymphoma in mice. However, the tumor to normal tissue toxicity ratio in this system is small so that it provides a 
model suitable for the study of permutations designed to enhance the therapeutic ratio, i.e. enhanced radiopharmaceutical delivery to the tumor.

\section{SPECIFIC OBJECTIVES}

The specific objectives for the coming year will move all NMR developmental work to the NIH funding we received for that project. However, we will use NMR measurements when helpful in the protocols $3.11-3.14$ designed to enhance delivery by various techniques. Biodistributions * at various protein, radiation and I-L2 levels of these protocols to quantitate the tumor uptake and radiopharmaceutical biokinetics. Selected protocols will be used for therapy studies, with the inclusion of needle dosimeters, histology, and NMR subset studies. The metabolic pattern will be followed after administration of curative and subcurative amounts of radiolabeled antibody as well as curative amounts of radiolabeled antibody administered in fractionated doses.

We will proceed with muring protocols for $3.11,3.12,3.12$ and a protocol for 3.14 will be prepared to follow. These protocols will be carried out in the lym-1 Raji mouse model first, but also in the L-6/breast cancer model. Protocols will utilize and compare the effects in the two mouse options, Lym-1/Raji and L-6/human breast cancer. A human protocol for 3.11 has just been initiated in patients with I-131 Lym-1 and protocols have been written, and have human use approval for $L-6$ for 3.11 and 3.12. Protocols now in use by our group with IL-2 alone will furnish the baseline for IL-2/Lym 1 and IL-2/L-6 protocols.

Addition of interferon murine and human protocols will follow if delivery/uptake proves to be suffering from the limitation of antigen express.

\section{TABLE OF MURINE PROTOCOLS}

3.11 Utilization of dose schedule and dose rate to enhance the vascular permeability for the followup doses.

3.12 Pre-irradiation with external beam or specifically timed predose of radiolabeled antibody.

3.13 Pretreatment or co-treatment of pationts with IL2 and antibody.

3.14 Pretreatment of co-treatment of patients with toxins and antibody

* Murine biodistribution protocol attached. 
$\square$

Tumor Volume Index (0.7 $\times \mathrm{mm}$. cubed $)$

?

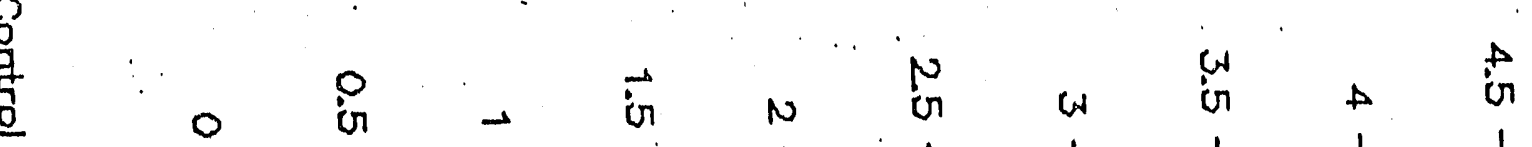

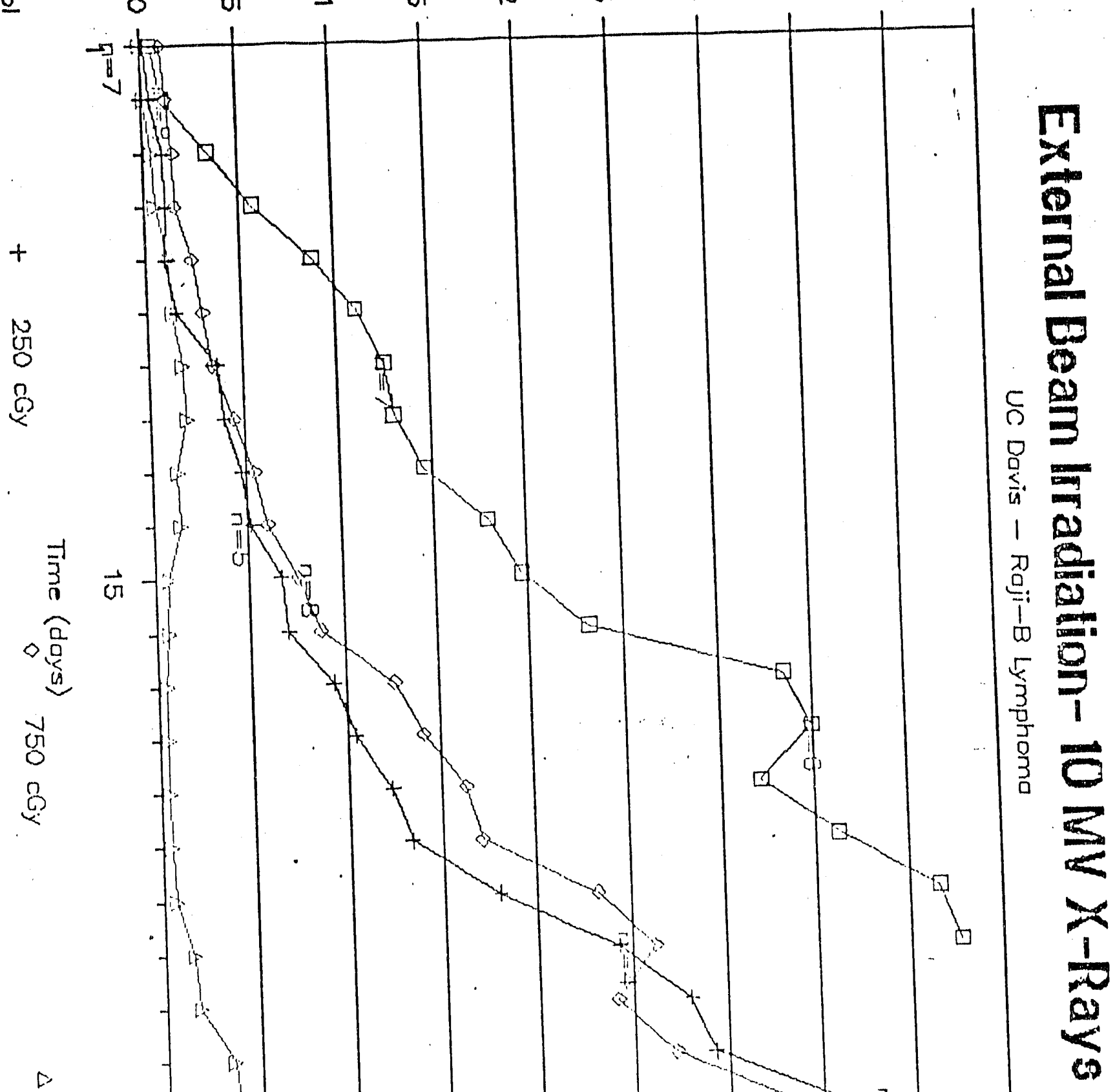

$\overrightarrow{0}$

年

证

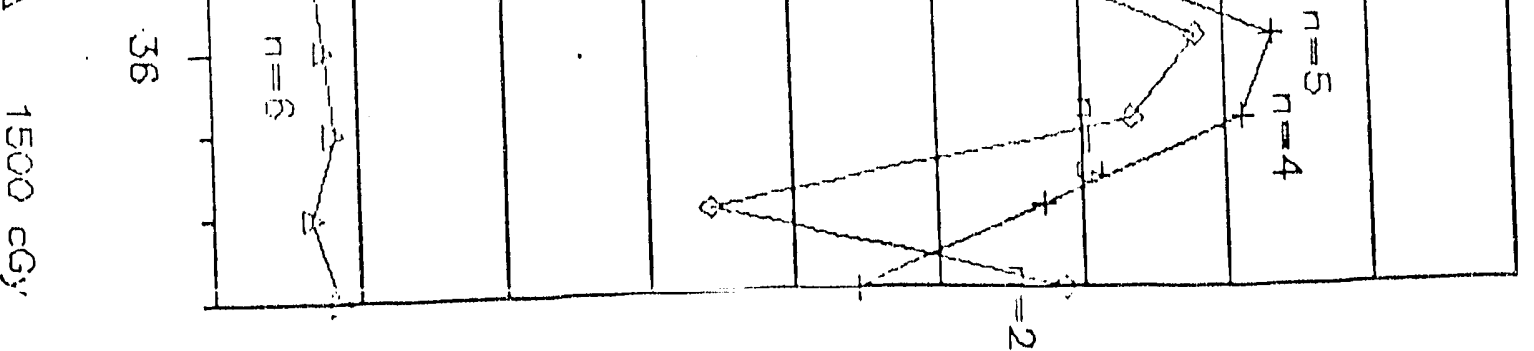




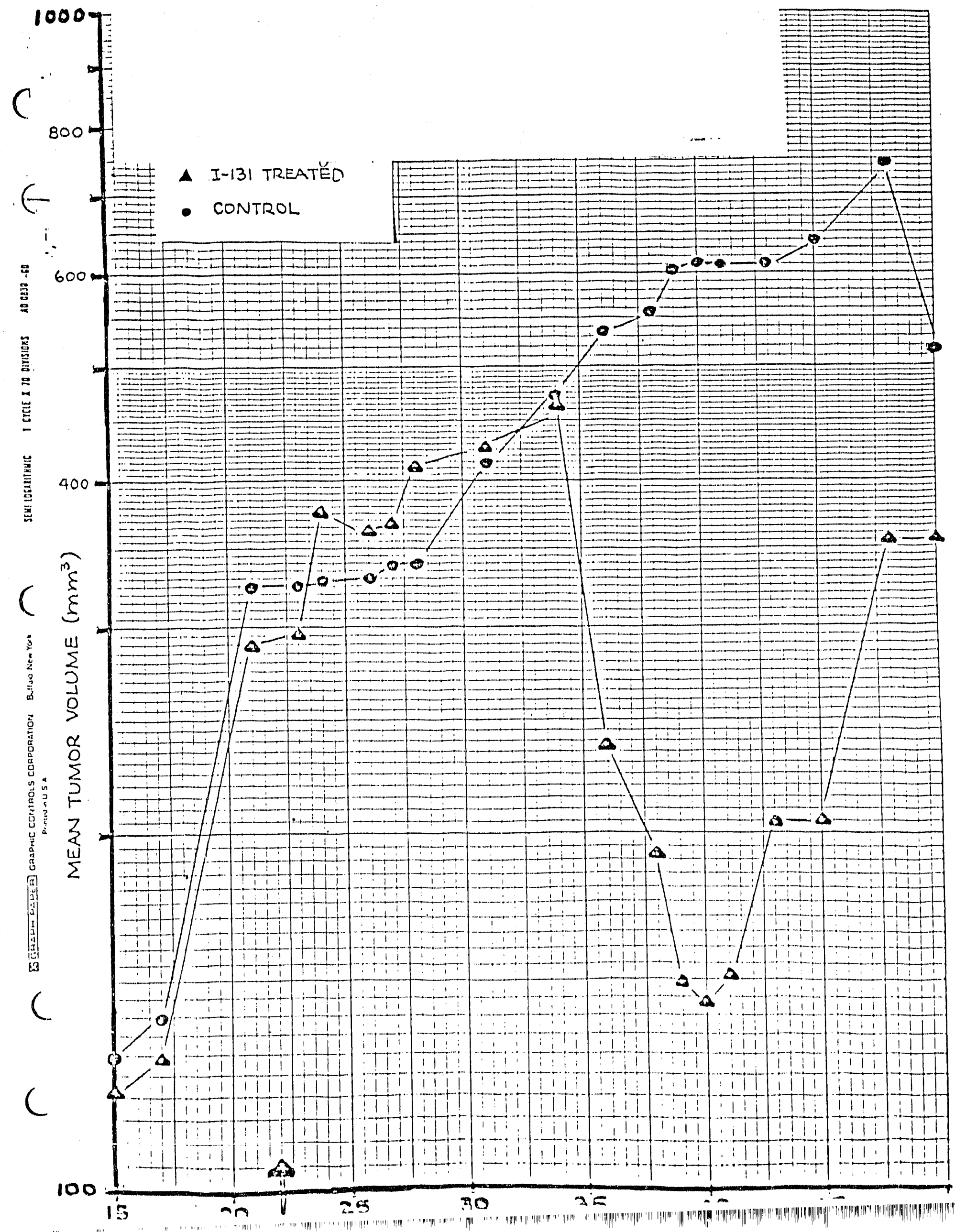


C

TO: DENARDO, Q. $\because$

MS : NUCLEEAR MED

FROM: Phil Tillmar, Campus Veterimariari

RE: Arimal Care ard Use Protacol \#Esot

RADIONUCLIDE DOSIMETRY; CANCER THERAPY; NMR TUMOR EIOLOGY.

Your arimal care ard use protacul for the project showr abave has been reviewed by the Arimal Use arid Care Administrative Aclvisary Cormittee (AUCAAC).

The protacal was aporaved by the cormittee as submitted.

This anproval is ir effect unt il $05 / 11 / 92$.

The ericlased Protacal for Arimal Care should be displayecl in areas where the arimals are ta be hallsed for perigds exceedirig é4 haurs. If your arimals are to be housed at ARS or at CFRC, a caoy á this protacal will be serit directly ta the vivariblin.

Shaud you have ary questiars about the status af this protacal ar the review process ir gereral, cartact the office at the carndis

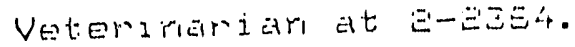




\section{MOUSE ORGAN DISTRIBUTION}

-..

\section{INTRODUCTION:}

This procedure was developed so that whole body disappearance rate and organ distribution of various radiopharmaceuticals could be tested in normal and tumor-bearing mice.

The method involves injection of mice, via the tail vein, with the radiopharmaceuticals(s). Whole body dose is determined at the time of injection and again after the desired metabolic time has passed. The total amount of radiophmaceutical injected into each mouse is measured by weighing a syringe before and after injection. A weighed standard (counting standard) is also prepared and diluted into a $50 \mathrm{ml}$ volume. Then a $1 \mathrm{ml}$ aliquot of the counting standard is counted in the sarne well gcometry as the tissue samples so that absolute tissue concentrations can be expressed as a percontage of the injected dose per gram of wet tissue. At the desired metabolic time the mice aro sacrificed and dissected, and the organs removed, weighed, and counted. From this data the injected dose per organ and injected dose per gram of tissue are calculated. The disappearance rate of the radionarmacoutical can also be dotermined by calculating the percent of the injected dose remaining in tho animals at the time of sacrifice, for various metabolic times.

WATERINLS:

1. Picker Dual Probe

2. Gamma Well Counter

3. Sartorius Balance

4. One test tube per mouse oran to be coldected. ('Tost tubas should be werghed with label on tube, then storat in a tost tube rack.)

5. Houge organ distribution liorms 
1.

6. Mice 20-25g (tumor approximately 14-15 days old)

7. Cages to store injected mice

8. Indelible marker

9. One cc tuberculin syringes with $27 \mathrm{G}$ ( $\left(y^{\prime \prime}\right)$ needle

10. Radiopharmaceutical(s)

11. 150 co Nalgene beaker

12. Funnel (to fit into $150 \mathrm{cc}$ Nalgene beaker)

13. Dissection tools (small and large scissors, tissue and regular forceps)

14. Dissection board

15. "Kimwipes" (tissue)

16. Paper towels

17. A beaker containing soapy water (to clean dissection tools)

18. Various eppendorfs

19. Monroe 1860 calculator and prograns

20. Lugol's solution (dissolve $50 \mathrm{~g}$ lodine and $100 \mathrm{~g} \mathrm{KI}$ in $100 \mathrm{ml}$ distilled $\mathrm{H}_{2} \mathrm{O}$. Add distilled $\mathrm{H}_{2} \mathrm{O}$ to $1000 \mathrm{ml}$ volume)

21. Heparinizcd micro hematocrit capillary tubes

22. Scalpel blades

23. Disposable gloves

24. Plastic bags

25. Small racioactive waste box

PRCCEUURE:

1. For one week srior to the experiment add Iugol's solution to tho drinking water of the experimental animals at the rate of one drop (5' solution of Lugol's) per $100 \mathrm{ml}$ of diriking water. This $i$ is to block iodine uptatio in thyroid.

2. Peak in tho picker Dual probo and tho Ganna itell Counter (see peaking procedure). Balance the probes of the Dual prode. Sat the wincons for the i.sotone to be used and note them on the worksheet. Decido wich organs and samples will be included in the distribution. put $12 \times 75 \mathrm{~mm}$ test tubes in test tube racks (one tube per mouse organ to be collected), and label tuies. Weigh each test tube carefully on the sartorius balance (making sure the balance is clean and roals zcro betore weighing). Note the weight of the empty test tibes on the mouse organ distribution forms. It is best to have the sane person who weighs the empty test tubes to also weigh tho test tubes after the organs have been placed in them.

3. Weigh each mouse and moasure turior siat. Focord the witght on the wowkstreet. 
4. Infect the mice in the latoral tadi vetn with about $5-10 \mathrm{HCl}$ of radioactivity in a weighed 1 co syringe with a $27 \mathrm{G}$ ( $y^{\prime \prime}$ ) noedle. Reweigh the empty syringe after infection and rocord tho wolght of the injected dose on the work shoot. Note the time of infection. The injection schedule should be proparty planned so that all preparations may be completed beforo sacriftca time. Count the mice immediately postinfection by suspending tho mouse inidway between the two crystals of the Plekor dual probo. This may be accomplished in the following way:

a) Immobilize the mouse by putting it into a $1.50 \mathrm{~mL}$ Nalgene beaker and then push a tighteltting, small funnel down on the mouse until it cannot move.

b) With a ringstand and a large clamp, one can now rigidly mount the boaker and mouse botiveen tho two cristals at a distanco of $30 \mathrm{~cm}$.

One must be caror'd to malnatin the same geomatry throughout the experiment. A standard containding about the same amount of radiogharmaceutical in a $50 \mathrm{ml}$ volume should be counted th the same geometry as the mico, so that decay may be easily distinguished from biological disappearance. Add the collnts from both raterneters to obtain the zero time $\left(T_{0}\right)$ wholo body counts. Record these values on tho worksheet. By taking whold body couns at various times throughout the experiment and counting tho standard, one can construet a whole body disapparanco cury. Rememser to subtract the background from the above colures.

5. A counessg seandarid to be used when counting the individual organs should be prepared at this time in tho following way:

a) Rinse a $50 \mathrm{ml}$ volumetria out with a protein solution which consists of 1 drops of lugol's solution (50), 2 in of plasma, and 50 mi of distilled wator,

b) ade $50 \mathrm{~nL}$ of distilled water to tho volumetrio,

c) add tho sarie amoune on radioactivity as in each individiul mouse dose,

d) bring to volume and mix thoroughly,

e) transfor to $150 \mathrm{ml}$ beater and take reading on duad prosia, and

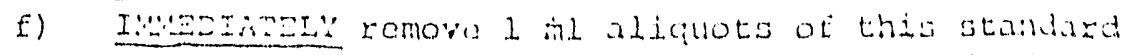
and pue from into tost abos lonowin standard tost: tiabs should bo proparod to have a standard at the

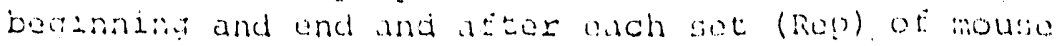

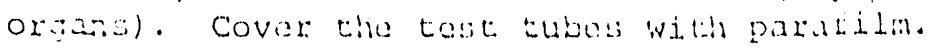


6. Blood samples aro collectod at various timas throughout the exporiment and juet prior to sacrifice by immersing the mouge's talil in vory warm watar for about 30 soconds, then wiplng the tail dry with a kimwlpo. Imrnediatoly niek tho dorsal tade veln with a scalpol blade. The blood 1 s then collocted in a hoparindaad micro hamatocrit capillary tube. Blood is forcod from the tubo wh th a 100 H.l appondorf with a yollow tip. Care must bo takon to got the sample as close as possible to the bottom of tho tost tube fllled with $1 \mathrm{ml}$ of water.

7. At the appropratio time, sacrifice the mice and count them on the Dual probe as beforc. Count wholo body with tail and without tail. Obtain the s ID remalning at sacrifice. Tf the tail contalns $>10^{\prime}$ " of the ID, omit the mouse from the study.

8. Dissoct out tho organs and collect any other sample(s) destrod and place thom in the bottein of weighod test tubas. Whon placing samplos in tho tubes try not to got part of tho sample on the tubo wallis bocause this wild. cause incorrect counts to be obtainod. Woigh tho tubes and record the weight of the tubes and samplas on the workshoer. Thon itill each tubo to a one $\mathrm{mL}$ hodght with watar to keep counting goomoexy more constant. Cover tho tubos.

9. Count the tubes, placing a counting standard at the beginning and and, and at approprate incoryls botween rops.

10. Do the statistics, obtaning s IDiorgan, is ID/gm, TUSOS/BLOOD,

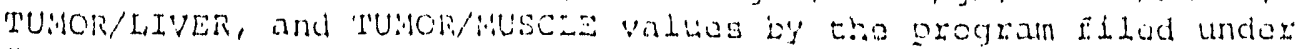
"ilonace progratis". 


\section{ANILEL DISTRIBUTION}

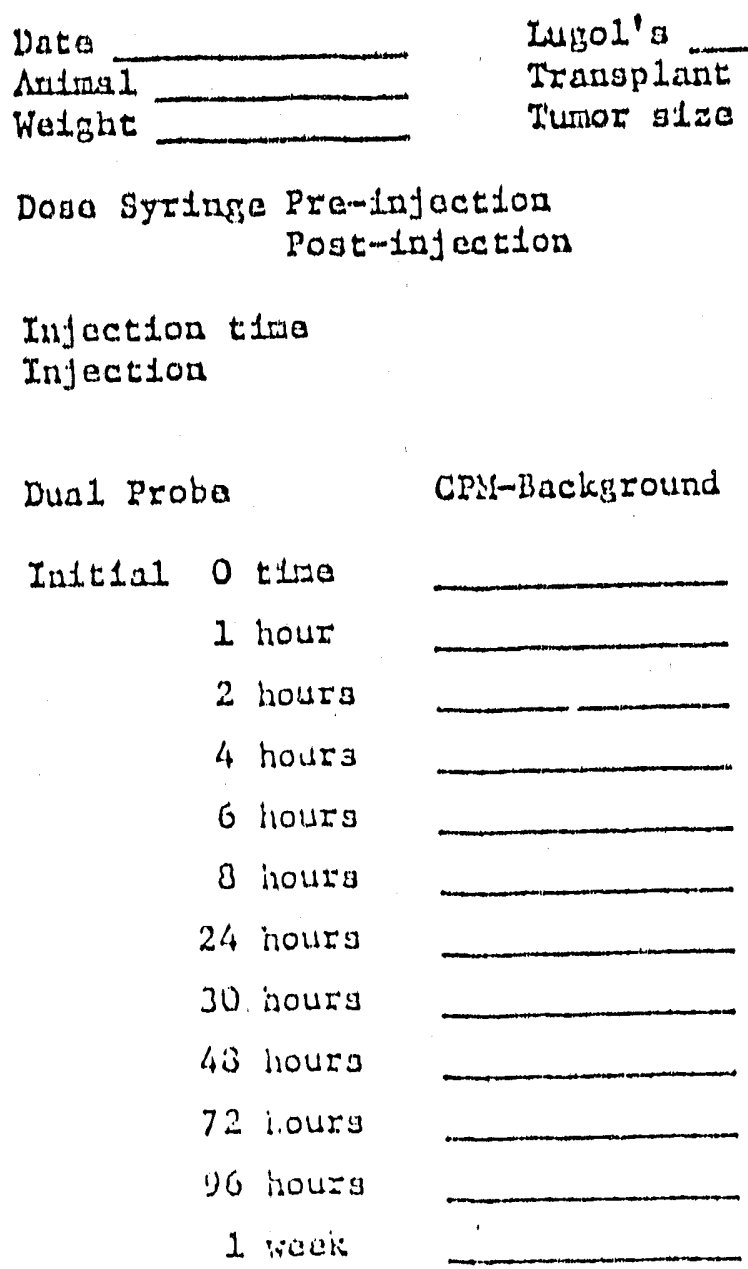

Dead aniand (rith tall)

Dead antral (whthout tall)

2 romaiufng ta tall

Carenss + Aosorbenta

Necrosts (turar)

Llood sasiple

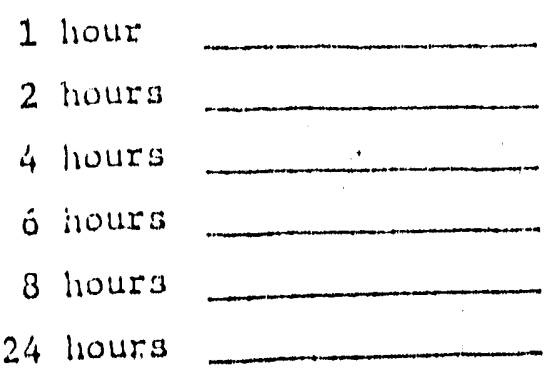




\section{ORGAH DISTRIIUTIOU}

Anious 1

Infected Dose

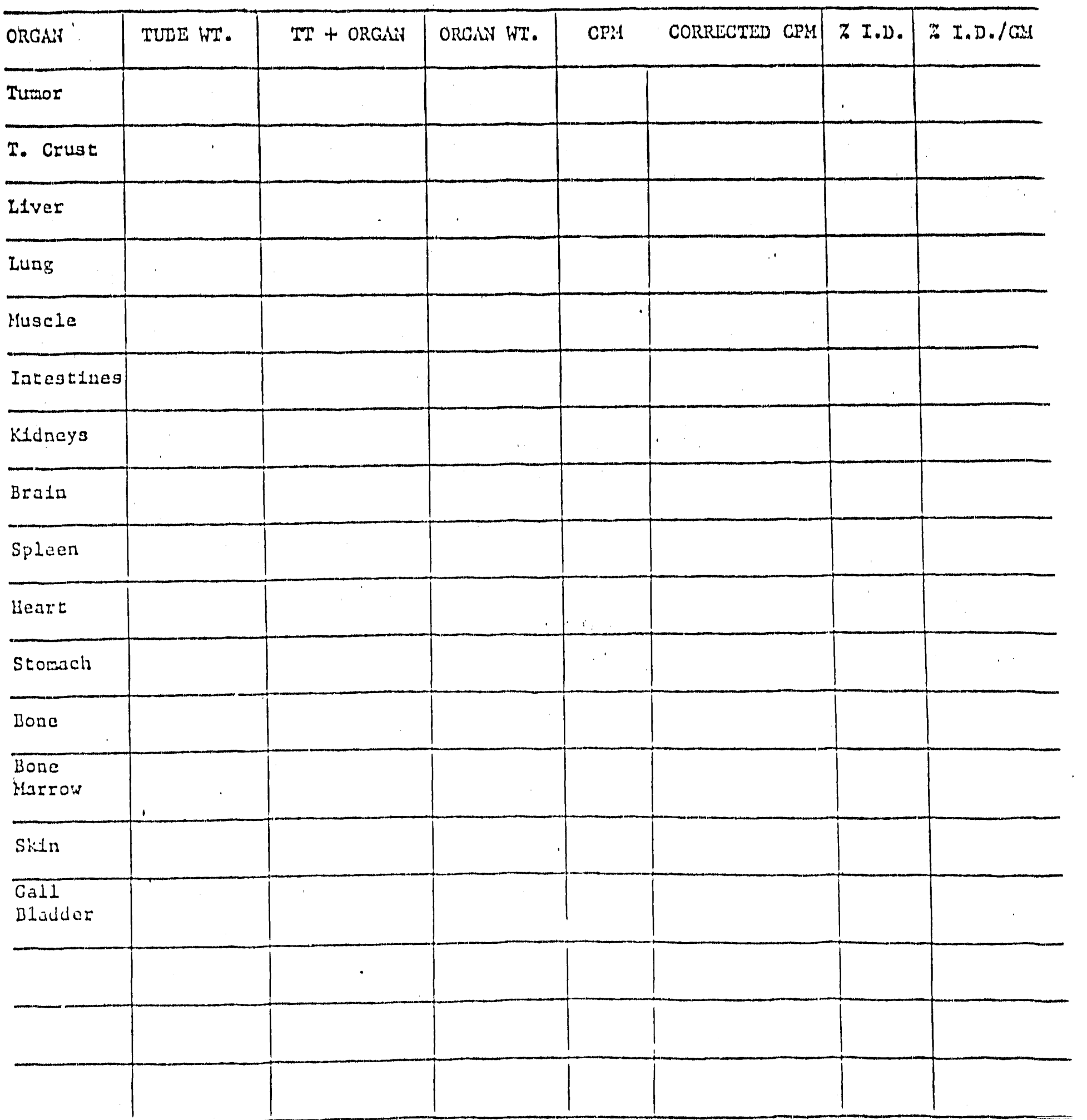


4.0 TO STUDY THE BIOKINETICS AND THERAPEUTIC POTENTIAL OF THE NEWLY DEVELOPED RADIOPHARMACEUTICALS

Studies in mioe and patients demonstrated that the radionuolide acoumulates $L$ r the liver and bone marrow after the intravenous injection of radiometal labeled antibodies. If the radiometal is retained in the ohelate of the antibody, then the tissue residenoe time of that radiometal oan be influenoed by providing a metabolizeable linkage between the chelated radiometal and the antibody. In order to address this question, five benzyl-EDTA based bifunotional ohelating agents were syntheslzed and oonjugated to an anti $B$ oell lymphoma mouse monoclonal antibody (MoAb). These ohelating agents contained either ester, peptide, disulfide, thloether, or thlourea linkages between the benzyl-EDA ohelate and the antibody. These bifunctional thelate conjugated antibodies were labeled with 11 In, 1 munologioaliy and blochemioaliy charaoterized in vitro, and studied in non-tumored BALB/o mioe. The blodistribution of these radiolabeled antibody conjugates showed that the whole body olearanoe was rapld for the ilin antibody conjugate with the disulfide linkage, ( $T_{1 / 2}=12 \mathrm{hrs}$ ) while the whole body olearance of the others varled between $T_{1}$ of 7 and 10 days. Twenty peroent of the radionuclide was in the Ifver during 72 hours after the injection of the peptide linked antibody wheras, $8.6 \%, 13.4 \%, 7.6 \%$ and $2.2 \%$ of the radionuolide was in the liver after the injeotion of ester linked, thioether linked, thiourea linked and disylfide linked antibody conjugates rospectively (Figure 1). 11 In excreted in the urine was stili in the benzyl-EDTA chelate form. These results demonstrate that the in vivo kinetios of the radiometal chelate portion of radiometal/antibody oonjugates oan be programmed by the antibody/chelate linkage. This work is belng extended to other linkages and to the chelates of therapeutlo nuclides.

TO STUDY THE BIOKINETICS AND THERAPEUTIC PO'TENTIAL OF THE NEWLY DEVELOPED RADTOPHARHACEUTICALS:

4.1 In animals (kinetics and chosen therapeutic trials).

4.2 In patients (kinetics and chosen therapeutio trials).

4.3 Correlation of the therapeutio index of radiopharmaceuticals prepared with differences in the chemistry of attachment. 


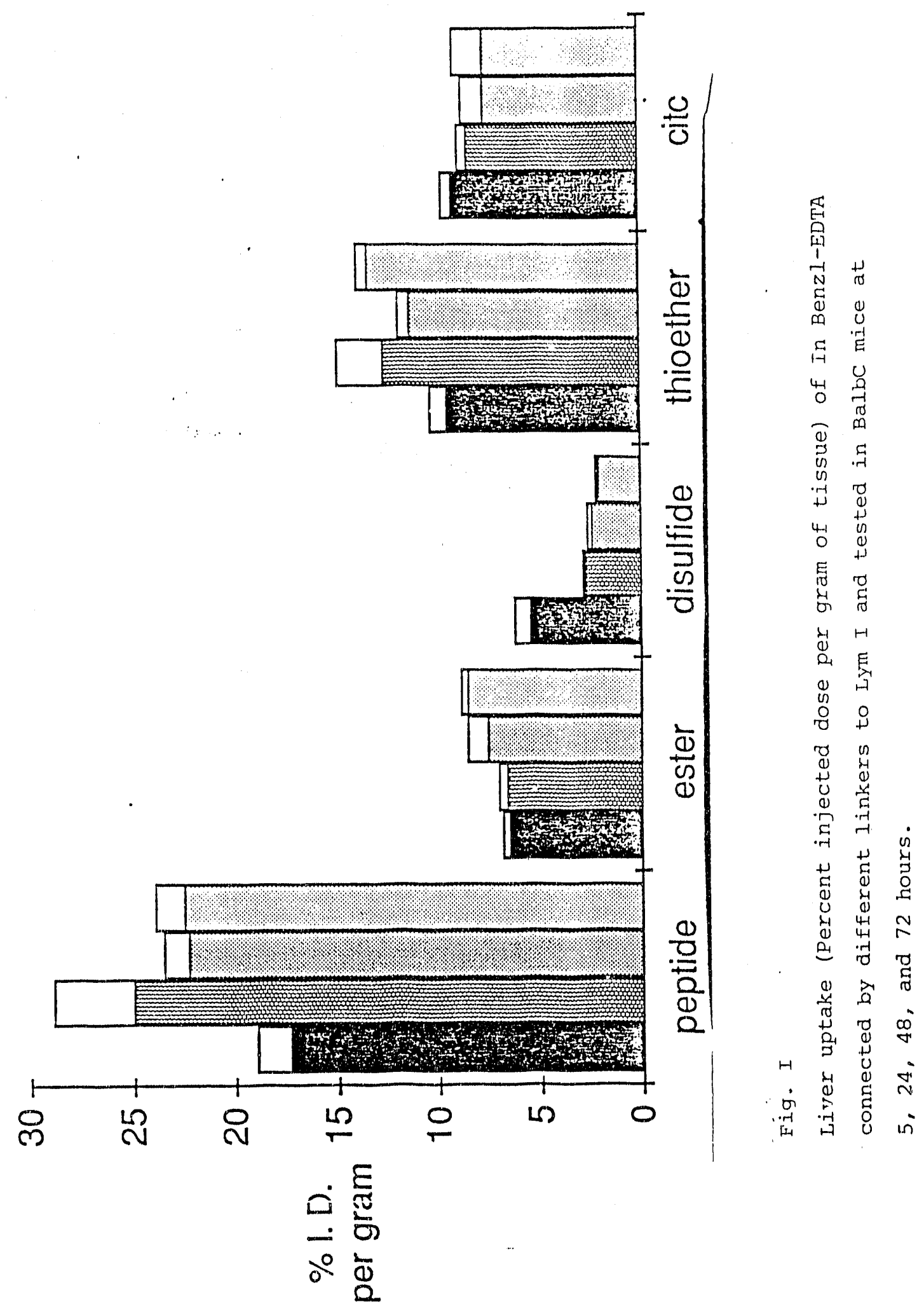


5.00 TO CORRELATE MACRO AND MICRODOSUMETRIC INFORMATION TO THE TUMOR RESPONSE RATE IN ANIMALS AND PATIENTS.

5.1 To use microdosimeters and autoradiography in animal therapy protocols and in patient quantitative pharmacokinetic/therapy feasibility protocols.

5.11 To determine the dose rate and variation and intra tumor.

5.12 To determine the correlation with mechanisms utilized to enhance delivery.

5.13 To correlate microdosimetry with histology and tumor response.

5.2 To determine the effects of dose rate and dose fractionation on tumor uptake and on tumor response in animals and in patients.

6.00 MONOCLONAL/TUMOR TARGET SELECTION.

6.1 To utilize the Moabs LYM-1 and LYM-2 antibodies in the lymphoma/leukemia studies.

6.2 To utilize the Hoab L-6 to study the delivery of therapy (per the above objectives) to breast cancer. 


\section{The Section of Radiodiagnosis and Therapy}

The Section of Radiodiagnosis and Therapy was recentiy established in recognition of the School and Department of Medicine's commitment to the development of antibodies and antibody-conjugates as vehicles for the treatment and managment of patients with cancer. The section has five professionals whose full-time effort is committed to research in this area, including two physicians, a medical physicist with interests in quantitative imaging and radiation dosimetry, a radiochemist with interests in developing linkers to attach conjugates to antibodies, and a radiopharmacist with special experience in the preparation of pharmaceutical quality antibodies and antibodyconjugates. This program directiy employs six research personnel and contributes to the support of research personnel in the Departments of Chemistry and Physics, and in some years in the Departments of Patiology and Anatomy, who are committed to this research effort.

There are generaliy six students involved in the prograin, including two immunology graduate students, and 1-2 faculty professors doing a sabbatical with us.

Twenty-five hundrad square feet house research space for the following activities:

1) Cell culture :or in vitro studias, tumored animal models and monocional anistody production

2) Diroct and insirecs aicroscop"

3) Immunoassiay

4) Immunochemis:ay inoluding various chronatographic (Pro $\lambda$, affinit:, no:coular sioving, high performance, etc.) and eloctrophrezis beomiques

5) Chenistry and adiconemistry

5) Antibody pharmay and radiopharmacy 
7) Quantitative planar and tomographic emission imaging centor with a state of the art SPECT scintillation imaging camera and computer solely dedicated to antibody research.

8) Four mini-computers, including a Vax II system, for image processing, data storage and analysis, image quantitation, and radiation dose calculations, and an IBM PC with $512 \mathrm{~K}$ memory, clock board, calendar, a 1200 baud modem and an IBY graphics printer.

\section{9) Reception area and offices}

The antibody research group at the University of California Medical Center in Sacramento has a state of the art, large field of view, gamma camera designed for 360 degree emission computerized tomography and whole body imaging with computer storage of all images. The camera is interfaced to a DEC MicroVAXII system with 2 MicroDELTA terminals. The Microvax has a 5 Mbyte CPU and two 71 Mbyte hard disks. One microDELTA has a 60 Mbyte hard disk and the other has a 10 Mbyte hard disk. Data analysis of images can be performed at each MicroDELTA terminal. A modem line links a VT 125 system with a VT 125 system with a graphics printer to the micro VAXii. This terminal is set up to run the HIH distributed SAAit program - Simulation, Analysis and Modelling of pharmacoisinetic data obtained from patient studies is modelled using this program. Input data include blood, urine, whole body retention, tumor and organ $\%$. Injected dose and models are generated that describe the response of the various compartinents in the body into which the radiolabeled lioib is exchanged.

Also an ADAC cama camera computer system DPS-1 exists in the research group laboratories for image data analysis, curve fitting and plotting.

The use of techniques for absolute quantitation of antibody amounts in orsans and tumors of patients provided the insights that led to our abandoning several antibodies of local and national intorest for targeting breast and other cancers in favor of pursuing an antibody (Lym-1) produced against Burbitt's lymphoma. Use of these quantitative imagine techniques in a fon patients provided absolute lata pernittine the conclusion that there was an antibody dose response for $6 y-1$ and tumortargeting culd be tripled by adrinistrition of a larger amount of Lym-1 antibody. These absolute lata vere dased in concert witia clearance of antibody to the mount of administered antibody, io that it is now possible to "dial in" a desired blood olearance for bisis antibod\%. The resuluant optinization of the conditions for use of this antibody conjurated with I-131 has contributed to

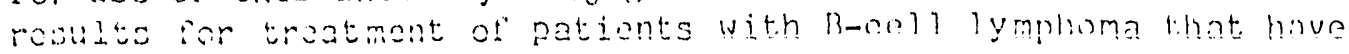
led somo pioneers in tho fiald to generously describe as being amone the most exciting achieved thus for. 


\section{RADIO-IMUUHOTHEARPY GRRIT - PATHOLOG̈ RESOURCES}

1. Flow Cytometry- Two flow cytometers, a Coulter Epics V and a Coulter Epics C are available at the U. C. Davis ilcdical Center Flow Cytometry Laboratory, under the co-direcision of Clarama ililier, Ph.D. and Arline Deizch, Ph.D. Both instruments are capable of four paranetar analysis, including dual fluorescence surface antigen detection, and Dila content analysis. Both instrunents have a cell sorting capability. To date, we have ulilized the instruments in this project primarily for surface immunophenotypins, including the detection and quantification of the Lym-1, Lym-2, and 113-1 Lymphoma antigens from prospecive paidents for radioimagine and imrunotherapy. Sequential studies have

a) followed tine effects of therapy on tumor mass,

b) assessed the extent of tumor antigen modulation over time.

c) corrolations with periferal blood $T$ coll and 3 cell subset populations. (i.a. E/S ratio)

Immunohistochemistry - Immunohistochemical detection of surface and cytoplasmic antigens in fixed and froacn tissues, and cytopreparations, is performed in ine Innuncpathology laboratorics of the UCDi:C Department of Patholos:. In current projects we have usad immunohistology to derine tho in situ morphology and distribution of liorib positive turinor cells.

III Holocuzar Patbology - The llolecular Patholog: Laboratory of UCDis, uncer the direcion of LDr. Raymond Teplita, is avalable er 3 and $i$ coll genotyjing. The laboratory is also con:yely snyolved in olifonucleouide probe technology and plozmerase chain raction amplisication. These resources could be utilized in future prosocols to dealne the mechanisms of anticon expression/modulation.

IV Morpholozic Hamepathology - ill patholozic and immunologio material is revianed by Dr. Hormal Levy, Director of Hematopachology. This macerial is presoned and discussed by Dr. Ley in bi-ilculy clinical Hemelonc pathology conierenees to the :!edical thenc/Onc and surgical oncology divisions at this same time. On the odd Veotis, Dr. Levy

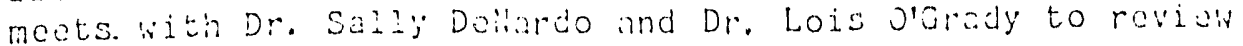
specisio dotails of pathology from the patients on immunoevisugate pravocols, or pationes being considered ar thase prov0001:. 

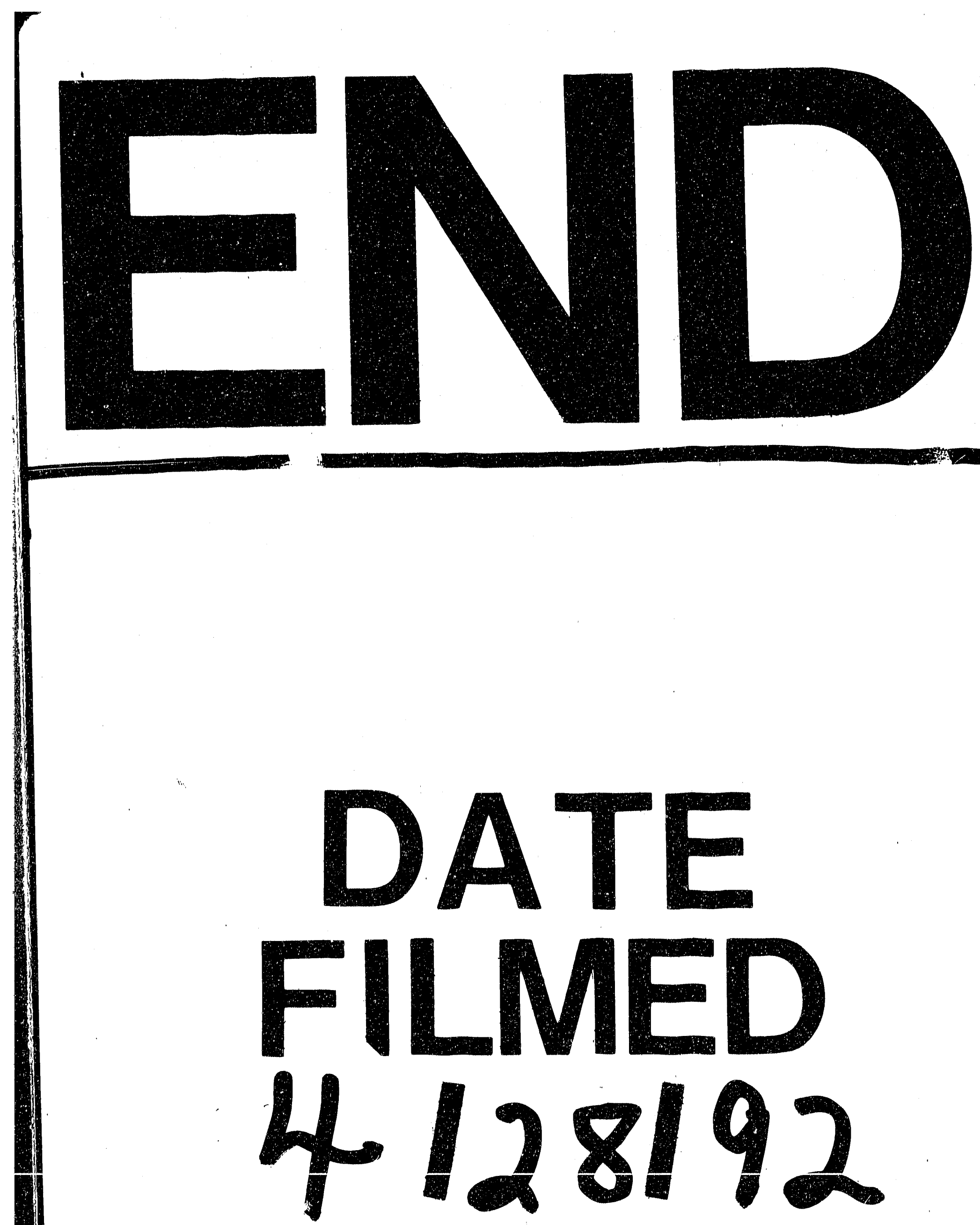


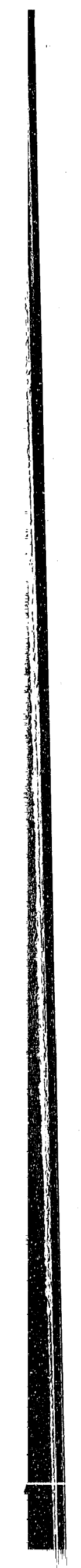

